8,3

3.7.

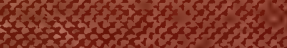

60 s.

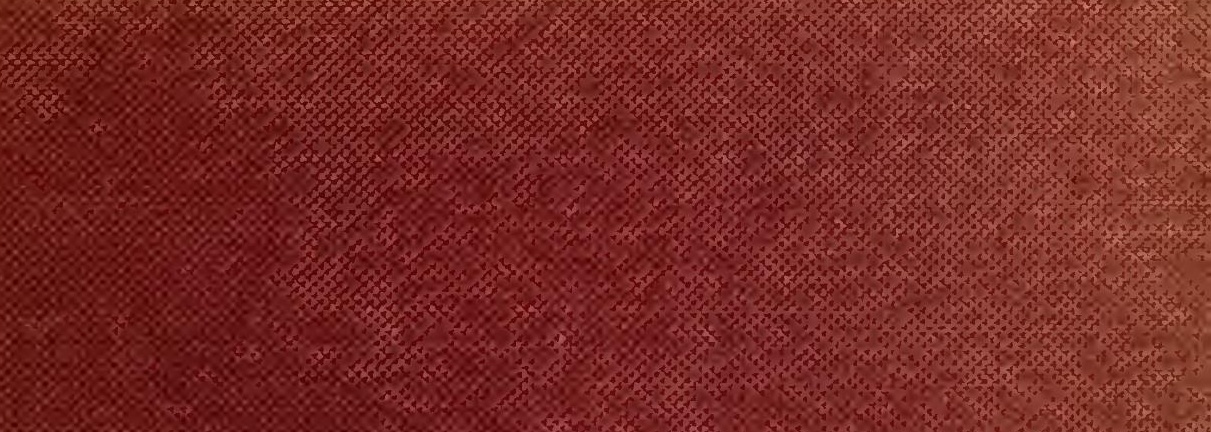
$8 \times 8 \times 08$

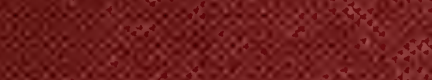
$8 \% 8$ (:) : (:)

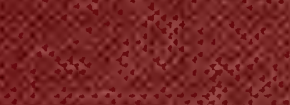
1.8\%

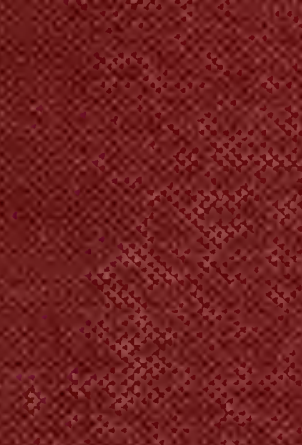
\% $8 \%$

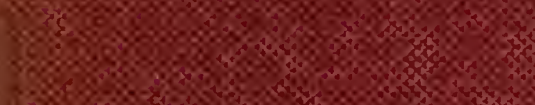




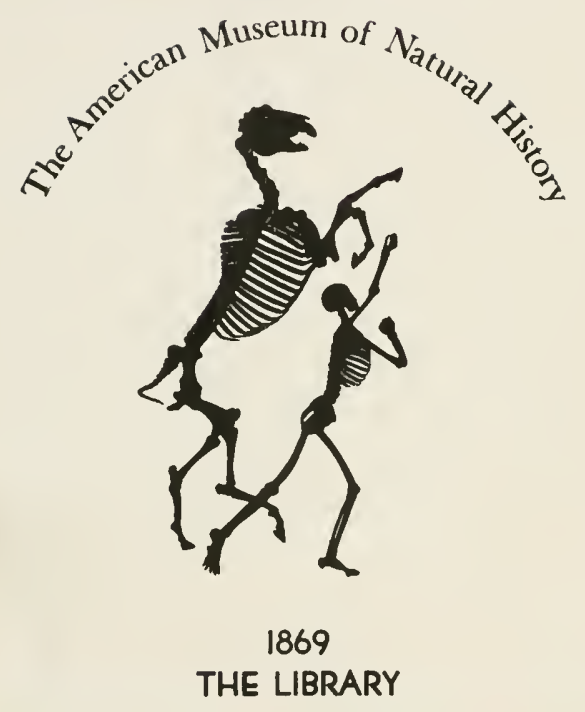



SHOOTING IN CHINA 




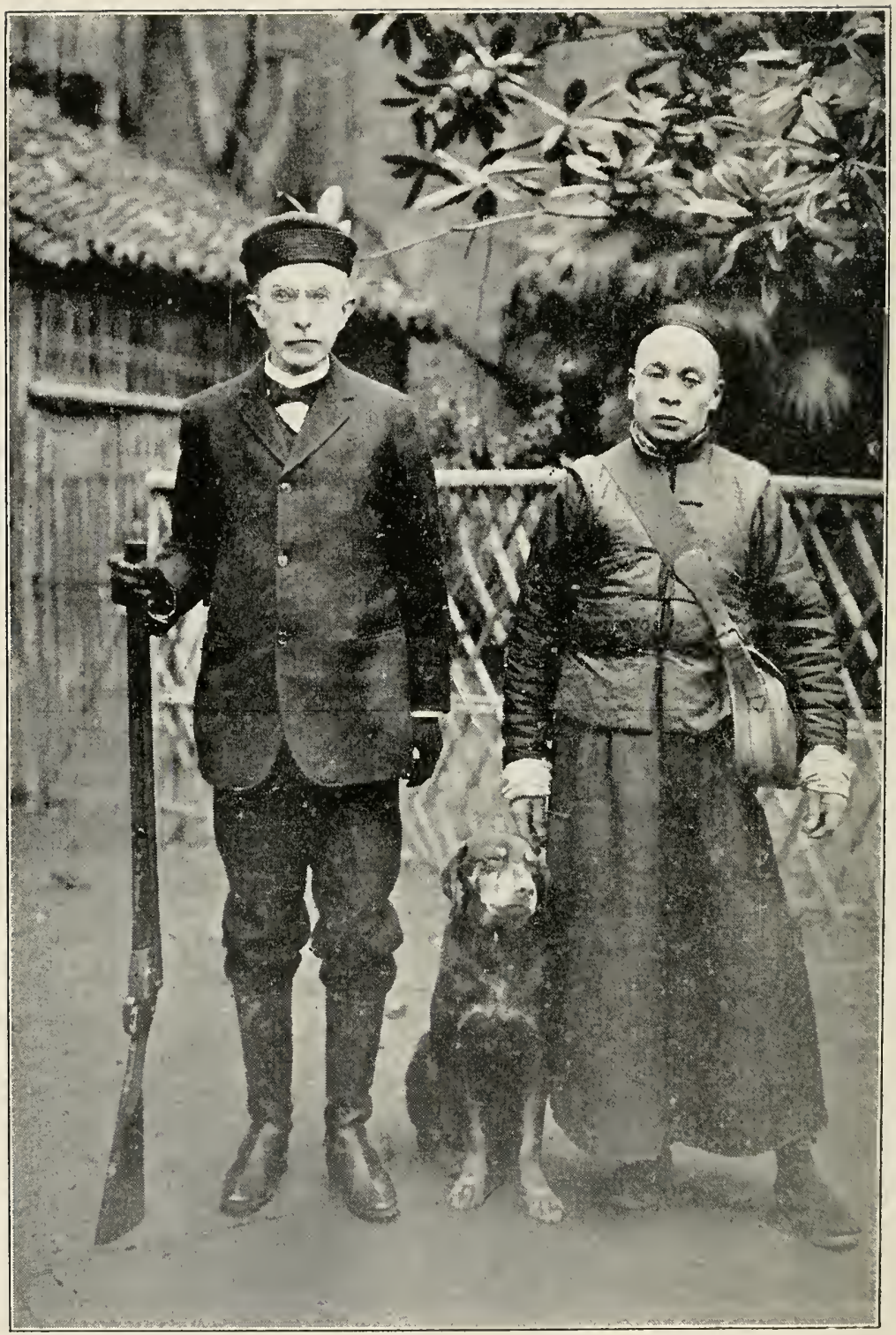

EQUIPPED FOR PHEASANT SHOOTING. 


\section{SHOOTING IN CHINA}

BY

'T. R. JERNIGAN

Author of China in Law and Commerce.

Methodist Publishing House

Shanglıai, China

Igo8. 



\section{PREFACE}

The following papers were written to give the new shooter in China a general idea of the equipments necessary for his snccess and comfort, and I have also ventured to submit some hints on the deportment that should be observed while shooting in the interior, but if I have succeeded in recording any incident which may remind the old "up-country" shooter of the pleasure of a day forever gone I shall feel gratified and compensated.

\section{T. R. JERNIGAN}

Shanghai, China. 


\section{CONTENTS}

CHATER
I. LANGUAGE-PEOPLE-MONEV




\section{ILLUSTRATIONS.}

EQUIPPED FOR PHFASANT SHOOTING - Frontispicce Facing Page.

FOREIGN HOUSEBOAT - $\quad$ - $\quad$ - $\quad$ - 27

Favorite Greaner Guns $\quad$ - $\quad$ - 33

"TELI" - $\quad$ - $\quad$ - $\quad$ - $\quad$ - $\quad$ - 47

Ringed-Neck Pheasant - - $\quad-\quad 65$

ReEves' PheAsant - $\quad$ - $\quad$ - $\quad$ - 65

GOLDFN PHEASANT - $\quad$ - $\quad$ - 67

LADY AMHERST PHEASANT - - - - 69

BAMBOO PARTRIDGe - $\quad$ - $\quad$ - 71

Mandarin DUCK - $\quad$ - $\quad$ - $\quad$ - 105

RhturNing From a Christmas Shoot - 149

ENTRANCK TO THE GORges - - _ - I7I 
CITY OF NITZE-FU

- $\quad-\quad-\quad-173$

IN THE GARDEN OF THE, MAGISTRATE, NITZE-FU 175

OUR HOUSEBOAT IN THE GORGES - - $\quad$ I8I

BALES OF STICKS - $\quad$ - $\quad$ - $\quad$ - $\quad{ }^{8} 8_{5}$

HAUl,ING HOUSEBOAT OVER A DIKE - -

Shooting Ducks on THE LAKES NFAR NINGPO 193

CHINHSE SPORTSMAN - $\quad$ - $\quad 209$

Chinfase Pun' SHooter - - - $\quad$ - $\quad$ - 213

EQUIPMENTS OF A CHINESE SPORTSMAN - 215

CHINESE DUCK CATCHER - $\quad$ - $\quad$ - $\quad$ - 223

Natives Having A "LoOK-SEe" " AT Foreigner - 255 
LANGUAGE-PEOPLE-MONEY 



\section{CHAPTER I.}

I.ANGUAGE-PEOPLE-MONEY.

After an experience of several years as a slooter in China I an convinced that the special subjects of this chapter are not irrelevant to the main subject I have selected to write about. Had I been informed on these subjects when I first came to Clina, as generally even as I am at present, the information would have been of decided practical convenience and the pleasures of shooting materially promoted. It is not $\mathrm{my}$ purpose to attempt to write technically of the language, the people, or the money of China, but rather to refer to some of the peculiarities of each with the hope of smoothing the way of the shooter who may come to this empire to enjor his sport.

Shortly after my arrival in China I atteuded the session of a Chinese Ccurt and soon observed that the judge was interrogating a witness by the aid of an interpreter. As the judge, the interpreter, and the witness were all of the same nationality the reason for such a procedure was not plain to me, and meeting the judge after 
the adjournment of the court I asked for an explanation. He said that as I had lived in China but a short time he could readily appreciate ny difficulty, and gave me this explanation: that as a judge of China was prohibited by law from holding court in his native province, it was necessary for him to have an interpreter faniliar with the dialect of the province in which the session of the court night be lield. I then inquired if China had no national language that was spoken and understood alike in all her provinces. He answered, that it was probable China did have a national language but that it was certain each province had a dialect peculiar to it and different from the dialect of any other province. I further inquired, if there was not a dialect or language a foreigner conld learn and which would enable him to make himself understood in any part of the empire. He thonght that the nearest approach to a national dialect was that known as the mandarin dialect, and if a fortigner or native was proficient in it the proficiency wonld prove of practical use in nearly all the provinces. I reminded the judge that the dialect he had named, as more widely spoken, was the 
youngest of the dialects, and it was strange that it should be the more national. He assented with the remark, that it was another of China's peculiarities, and that the longer I lived in China the nore I would see of them. I inferred that the judge was not fully convinced that China had a nation. al language, but seemed persuaded that it was not strictly accurate to say that there were sereral dialects. He instanced the fact : that the language of one of the provinces was as old as three thonsand years, and althongh it had served as the medium of business and communication for so long a time between the inlabitants it was not spoken or nuderstood ontside of that particular province. But whether there be a national language or many dialects, or whether there be different languages, scholars have no more agreed than they have as to the origin of the Clinese, and after reading the learned researches on both subjects there is a feeling that the true sources liave not been discovered.

There is, however, a useful view of the subjects which is of interest to the shooter and more so to the business man, for unless one is familiar, or has an interpreter who 
is, with the dialect of the province which he wishes to visit, lie had as well not go there, if he goes to learu the customs of the inhabitants. I do not mean that to enjoy slooting in China the shooter shonld understand the language, nor do I mean that he must incur the expense of an interpreter, but if lie lias an interpreter wlio knows the dialect of the neighbourhood in which he decides to shoot he will learn much that will be useful to his enjoyment. And it simonld be emphasized, that however proficient an interpreter may be in the dialect of one province he will probably be totally ignorant of that spoken in another; and this is a peculiarity the judge very likely had in mind when he intinated that I would learn many if I resided in Clina long. I was first impressed by the radical difference in the dialects of the provinces when on a visit to Chefoo during a summer season. I took with me ny Clinese servant boy, who had been in my employment for sometime, but I liad not been in Chefoo a day before becoming aware that he conld not understand a word of the Chefoo dialect. 
or make hinnself understood, so dissimilar were the dialects of Shanghai and Chefoo.

And not only are the provincial dialects distinguished by radical differences, but often in the sanne province each neighborliood lias its own dialect, and frequently in the same town or city those living on one street do not understand the spoken language of those living on another, althongh the streets are so near together as to seem an extension of the same street. The differences in the spoken dialects are not superficial, but each dialect is distinct in its rudinent and pronunciation.

However fundamentally the spoken dialects mily differ, one learns another of China's peculiarities in connection with the language or dialects when written. While the people who live in different provinces or neigliborlioods or on separate streets cannot make thenselves orally understood, the written language or dialects is a medium of intelligent connumication throughout the empire. If a resident of Peking were to visit Canton he would find it extremely difficult at best to converse orally with a resident of the latter city; but if he reduced 
to writing what he wished to say the Cantonese conld read and understand it as could the Pekinese any written answer.

No one will suppose that it is necessary to speak Chinese, or employ an interpreter who can, in order to shoot more accurately a pheasant or a bamboo-partridge, but when the weather is unfavorable and the shooter has to remain on board his houseboat the opportunity offers to inform himself about many interesting customs. If the houseboat. be anchored near a village or town he can easily liave a few of the leading residents at tea, and through a competent interpreter, thus acquire a knowledge of such custonis, the observance of which will insure a pleasant sojonrn and snccessful shooting. It is the minor customs that throw light on the larger life of the people, for the true history of China is the history of the family.

While the langnage and dialects really appear to have been framed to debar all intercourse between China and other nations, and it is said that neither enters any longer into the law and commerce of the world, yet, in view of the possibilities of Asiatic development, they never enjoyed a 
more interesting and commanding place than at this time. The language and dialects are written and spoken by the greatest number of the inliabitants of the world, are the medium for transmitting their ideas and are more widely diffused than any other. The books written in it have more readers than the books written in any other, and there are no people so completely under the influence of their literature as are the Chinese. Confucius lived twenty-four hundred years ago, but his writings are still the classics of China, the source and foundation of Chinese law, and the standard by which all rights and punishments are measured. The writings of this author, among the Chinese, take the place of the books on religion, and have modeled the form of their govermment as well as defined and regulated authority.

The foreigner who knows the mandarin dialect has an advantage over the foreigner in China who does not know it; the former acquires information by communicating directly with the natives, which is to be preferred, however proficient and reliable may be the interpreter. And in undertaking 
to learn the language it should be remembered that there is a material difference between that spoken and that written, for, as already stated, one may speak the language withont being able to write it, or one may write it without being able to comprehend it when spoken. Some of the best authorities do not think it difficult to learn the mandarin dialect if mistakes, reacling the rudiments, are not made at the beginning of the study. It is easy to procure a qualified instructor.

It is probable that the first impression received by the shooter will be that all the Chinese speak the same languacre and that all are alike, but the characteristics of the inhabitants of the provinces are as nulike as their dialects. If the Chinese have a national language, or if they be of the sane race, there has certainly been an upheaval of some lind which has scattered both. They may be as united as the sea although they appear more divided by dialects and racial characteristics than its waves. A native of Tientsin could not pass himself as a native of Shanghai, and the converse would be as true. If the dialect of a 
native of north China did not indicate the section from which lie hailed his dress, bearing and manner would locate his nativity. Wlyatever direction one may travel in China, whether north, soutl, east, or west he will find that the inluabitants of. each geographical division have their special custouns to which they strictly adhere as the guide of their daily intercourse. And these customs are nore restricted in area than would appear implied by the term geograplical division. As different dialects are spoken by the inhabitants of the same province, so in the san1e province custonis materially different may be found to prevail. 'The residents of the same city are sometimes divided like unto separate principalities, each principality being governed by its own particular custouns. And so deeply gromnded is the pride of provincial nationality, that a resident of one province visiting another is regarded almost in the same light as if lie were a foreigner. If the provinces should adjoin, a sinilar reticence marks the intercourse as if tlie provinces bounded distant parts of the Empire. 
When such are some of the characteristics of the people of China the slooter need not be surprised if his reception is not alike in all the provinces he may visit. In one province lie may be cordially received, but as soon as he crosses the border into another he may not be long in detecting an unfriendly disposition in the sullen aspects that greet him. But he must not be discouraged, for if somewhat liberal he will quickly perceive that he has friends only. A Mexican dollar is the diplomat in China before whose influence all difficulties disappear as the mist before the rising sun.

It will be of interest to have an idea of the distribution of the population, because there are more native shooters than formerly and it is not advisable to look for game $i_{11}$ the thickly populated sections of the Empire. China is in no sense evenly populated; in some provinces the population is dense while in some it is sparse. The great plain of North China, the Yangtse basin, the Szechu'an tableland, the coast regrion and the Si-kiang delta are the most densely populated parts of the Empire. The provinces which have 
the largest population are Szechu'an Shantung, Hupelı, Kuangtung, Kiangsi Kiangsu, Nganhuei and Fokien; in each of these eight provinces the number of inhabitants ranges from sixty to twenty millions. And the provinces which are least populated are Yunnan, Chekiang, Kansu, Shensi and Kweichow; in each of these the number of inhabitants ranges from twelve to seven millions. The above estimates are taken from Richard's ex haustive and anthoritative book entitled, "Comprehensive Geography of the Chinese Empire". In estimating the population of China this authority admits the well nigh impossibility of an accurate estimate, but taking the number of households as a basis the approxinuate population is put down at four hundred and ten millions.

The shooter should not conclude that he must shoot in the sparsely populated provinces only. In the Yangtse basin, which is densely populated, plieasant and wild fowl are plentiful and it may still be designated as the "happy hunting ground."

The money of China is another subject the shooter should know something about or 
he will be continnally annoyed as he travels in the interior; and the money has its peculiar character as do the language and the people. It is as different from the money of any other nation as the language and people of China are unique in their dissimilarity. China has no currency of a standard value like England and the United States. The nearest approach to a currency is a copper coin well known as "cash," and which has a square hole in the middle for convenience in stringing. "This coin, a generation ago of the nominal value of one twenty-fiftin of a penny, and now representing the fortieth of a penny, has a standard weight of fiftyseven grains of metal of which it is madeof copper and as much spelter of zinc (sometimes lead) as the copper will take up. 'This copper coin, of which it takes 9,600 to make a pound sterling, is the currency of the people; in it the farmer receives the price of his produce, and with it lic buys the things needed to satisfy the simple wants of his family. The millions know no other coin, and by its agency is carried on the whole of the retail trade of the Empire. Transactions which in England 
are settled with the three ninetals are in China settled with copper only; and this quaint coin is one of the most important of the links which bind the Empire together. Even in this coin the Chinaman shows his inevitable tendency to create differences. With the exception of one spot, Peking, the coinage is nniform thronghont China; but in the northern provinces, of which Slianghai and the metropolitan province, Chihli, may be taken as examples, eacli coin counts as two. The housekeeper does her marketing with six ponnds weight of coppers; in mid-China and the south she calls this amount one tiao (or I,ooo cash), and in north China she calls it two tiao; in the sonth she will be asked 50 and in the north roo cash for the same article, but in both she will pay ont 50 coins. The capital, Peking, possibly from patriotic motives, possibly because it was muder the eye of the government, was alone in accepting, and continues to this day to use the token coinage issued during the Taiping rebellion

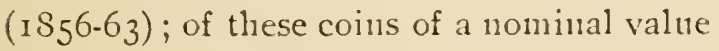
of Io cash, it would take Ioo to make the tiao of rooo, but being in the north each 
coin connts for twice its face value, and in: the tiao are only 50 coins. To prevent misunderstanding it should be stated that this patriotic acceptance of a depreciated coinage does not involve any loss to shopkeepers or custoners; the purchasing power of the coin is rated very closely by the amonnt of metal contained in it, and the length of cotton sheeting bought by ove tiao at Shanghai would command a price of cight or ten times at Peking" (Morse). The above quotation is from a paper prepar. ed, specially, on the currency of China, by H. B. Morse who, for a long time, has been at the head of the statistical department of the Imperial Maritime Customs of China, and is one of the very best anthorities on the subject. The shooter will now understand why the currency that is most in general use among the natives will prove inconvenient as a medium of defraying lis expenses, for in the place of one Mexican silver dollar he would have to carry six pounds weight of copper as the fractional equivalent. If he expected to travel or shoot for a month or tivo it would require several ponies to carry the "casli" he would need or an additional 
houseboat to the one used for his comfort and shooting equipnents.

There has never been in China a government coin of any other metal than copper, and the currency of the Enpire, other than copper, is not a coin, but a weight, and this weight is known by foreigners as the "tael", while the Clinese name it "liang". The tael which has the greatest degree of universal currency, and which is best known to foreigners outside of China, is the Haikwan, or custom's tael. The Haikwan tael is the currency in which duties are paid to the Imperial Maritime Customs and is the one meriting more special attention. "It is a weight of $5^{3} 3.3$ grains of pure silver 1,000 fine; expressed in terms of the silver dollar of $4121 / 2$ grains 900 fine, one Haikwan tael equals I.57 I 3 silver dollars. Introduced under the treaty of Nanking, I842, the lapse of sixty years has not sufficed to create modifications in this standard which, moreover, is current for revenue purposes in all the ports open to foreigil trate. Even with this currency, however, this immutability las to be taken with sone 
reservation. It seldom happens that the merchant has at hand to pay his duties the fine silver $(\mathrm{I}, 000)$ which is, theoretically, the standard of all payments to the government; and tendering other silver, coin money the ordinary trade silver of the place, the rate at which it shall be accepted becomes a matter of arrangenent with the banker; the latter having to account to the government for a certain weiglit of silver r,000 fine will be careful to cover lis liability. Another elenent of variation, even of this currency, is the difference between receiving and paying rates in force in all government treasuries, all banks, and with those merchants of sufficiently strong standing to make their own counting-house rules; this difference, usually between a quarter and a half per cent, is made, not by cluarging a commission, but by boldly using two sets of weights, one for receiving and the other for paying, and is intencled to compensate for the labour of weighing ingots and lumps of silver of no fixed weight, and for the risk incurred and expert knowledge requisite for taking in silver of unknown degrees of fineness. The practice 
is defended on the same grounds as that of the foreign exchange banks in quoting different buying and selling rates for bills of exchange". (Morse). The Kuping, or treasury tael, as its name would inply, is the currency in which are collected all other dues to the government other than customs duties, excepting only those which are levied in kind, such as the grain tributes, or in copper. The Shanghai tael is the standard of international exchange for the trade of North China and the Yang-tse basin, all other quotations in local currencies being re-conversion from the rate for Slianghai currency." A century ago Germany was the paradise of the money-changer with its countless coinages, each circulating in its own principality, but that was simplicity itself when compared with China. In China every one of the hundreds of the commercial centers not only has its own tael weight, but in many cases has its several standards side by side; and these taels of money will be weighed out in silver which, even in one place, will be of several degrees of fineness". (Morse). An example of this confusion in 
the currency will be informing on the subject, and one town may be taken to typify many. "In the town of Chungking, in the province of Szechu'an, in the far west of China, the standard of weight of the tael for silver transactions is 543.7 grains, and this is the standard for all transactions in which the scale is not specified. Usually, however, a modification of the scale is provided for, depending in some cases upon the place from which the merchant comes or with which he trades, and in others upon the goods in which he deals. A merchant coming from $\mathrm{K}$ weicliow, or trading with that place, will probably, but not certainly use a scale on which the tael weighs 537.3 grains. A merchant from Kwei-fu, a town on the Yangtse, a hundred miles from Chungking, will buy and sell with a tael of 550.7 grains; and between these two extremes are at least ten topical weights of tael all current at Chungking. In addition to these twelve topical currencies, there are others connected with commodities. One of the most important products of Szechu'an is salt, and dealings in this are settled by a 
tael of 544.5 grains, unless it is salt from a Szechu'an well, in which case the standard is 545.7 grains. A transaction in cotton cloth is settled with a tael of 543. I grains, but for cotton yarn the tael is $544 . r$ grains. This seens confusion, but we are not yet at the end; up to this point we have dealt only with the weiglit on the scale, but now comes in the question of the fineness of the silver with which payment is made. At Chungking three qualities of silver are in common use, "fine silver" I, Ooo fine current throughout the empire, "old silver" about 995 fine, and "trade silver" between 960 and 970 fine; and payment may be stipulated in any one of these three qualities. Taking the score of current tael weights in combination with the three grades of silver, we have at least sixty currencies in this one town." (Morse).

A tael is supposed to weigh as 11utch as one ounce of silver, and as it requires 9,600 copper cash to make one pound sterling, the shooter need not be again reminded how inconvenient it would prove if he supplied himself with the anlount in Chinese money he might need. If the copper cash or the tael possessed a fixed value 
throughout China the inconvenience would still be great, but when there are about seventy local varieties of tael, each differing slightly from every other, as one proceeds from place to place, the shooter would have more trouble in keeping up with the value of his money than he wonld with the most cunning of cock-pheasants.

But the shooter must not be disconraged by the different dialects, the characteristics of the people, or the confusion of the money, for the difficulty of smoothing his way through it all is not insurmountable. China is still the "happy hunting ground," and if one begins with a general idea of the situation, and is a true sportsnuan, he will soon experience that no conntry surpasses China in the opportunities for real enjoyment. If the services of a properly qualified interpreter are engaged there need be no serions thonght of the peculiarities of the language or the people, and as to the money, in use among the Chinese, the advice is not to trouble about it, for if the shooter supplies himself with the requisite number of Mexican dollars he will have no reason to concern or perplex his mind by 
calculating the value of a "cash" or a "tael." There is scarcely a place in China where the Mexican dollar is not current either to be exclianged at the banks or to purchase whatever may be needed. The natives have a convenient system of banking, and in most any city or town the shooter will find one or more native banks at which he can exchange his silver or the bills of any of the foreign banks doing business in China, especially the bills on such well known banks as the Hongkong and Shangliai Banking Corporation. 



\section{HOUSEBOAT-GUN-DOG}





\section{CHAP'TER II.}

HOUSEBOA'T-GUN-DOG.

In the view that comfortable steamers are running on the principal waterways of China and travel by rail is annually more convenient, it may be asked why should a houseboat be considered a necessary equipment to successful shooting? It is true that one may travel with every reasonable comfort on steamers more than I,500 miles up the Yangtze River and see on either side the plains and hills which are the feeding grounds of the favorite game birds, but that would not be shooting. If the trip up the great river be undertaken there must be some stopping place decided upon and when the shooter has arrived at it he will then fully understand why the houseboat is an equipment essential not only to his success but to the preservation of health. The steamboat and the railway will be a convenience as to reaching any place on their lines, but these agencies of commerce and civilization have always proved destructive to gane, because of the facilities afforded the shooter for travelling. 
At this time there are comparatively few miles of railway in China, but thus far wherever the steam-engine has gone the game birds have taken their fight from the lines of travel. The pheasant, woodcock, and the deer cannot live and prosper long when they have to contend with the railways and the breech loader. No country in the world surpasses China in natural waterways. However China nina be interlaced in the future with railways her inland creeks and canals will prove the medium for conveying to the markets the products of the vast farming population; and if the shooter wishes to visit the best places for shooting he will have to travel in a boat suited for the inland waterways of the Empire. It is, therefore, that the houseboat is an essential equipment; and now I will describe such a one as the shooter will find accomodating for comfort and travel.

If the shooter resides in China he will probably own a boat - such a one as will please his fancy and convenience; but if he comes to slioot for a month or so it would be to his interest to hire a boat and this he can do at one of the open ports. 



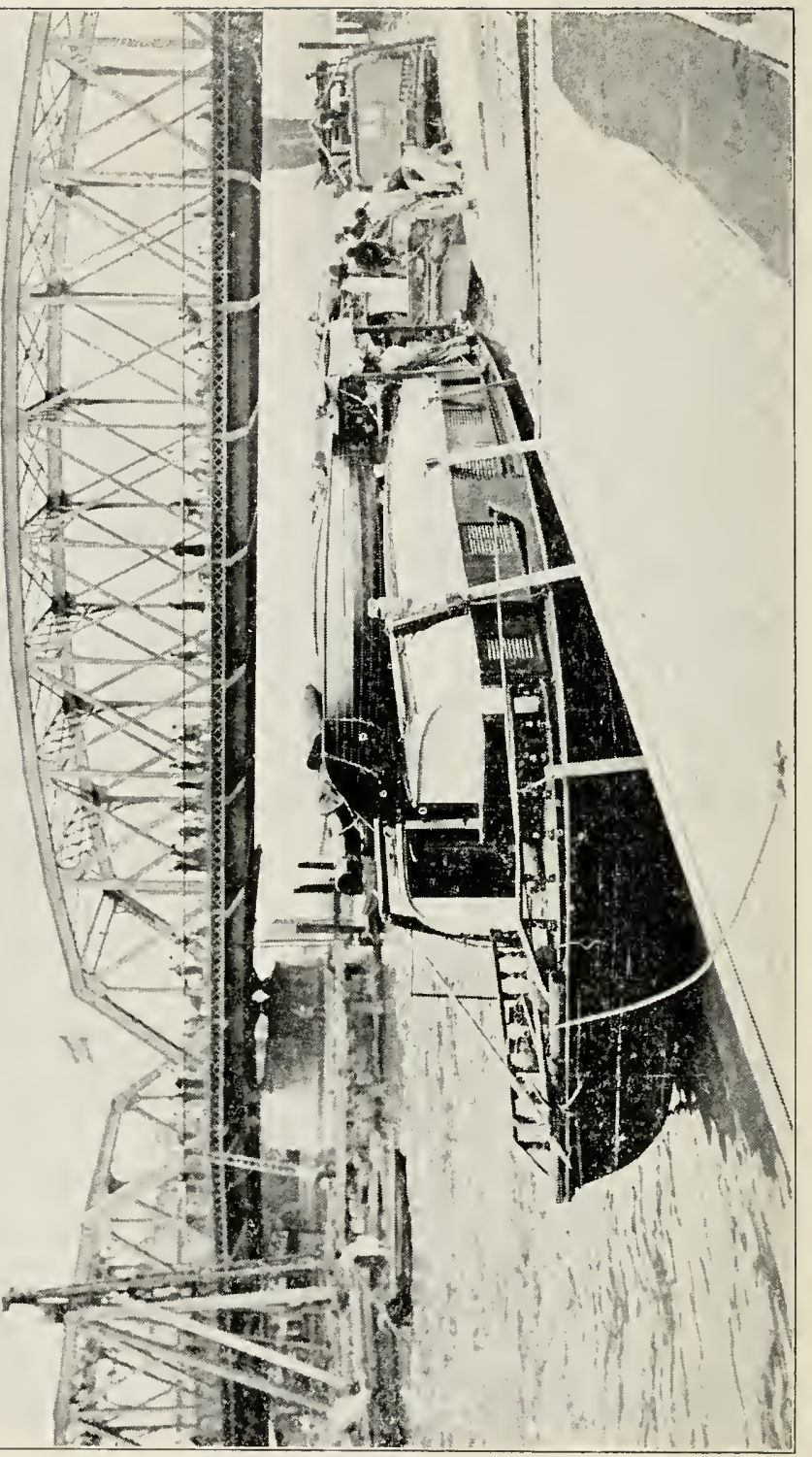

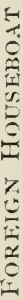


Shanghai is usually the open port where the shooter first enters, and at that port he can with more intelligence take his latitude and bearing. At Shangliai he will seldon have any difficulty in liring a boat that will prove suitable and at a reasonable price, as there are a larger 11 mber of houseboats at this port than any of the other open ports of the Empire and a satisfactory selection is more easily made.

But in the words of an old shooter in China, as "no three men agree about the dimensions, build and fittings most suitable for a perfect shooting boat," I shall give the general opinion only on the subject.

The concensus of opinion among the resident sportsmen is that a first class houseboat should be at least forty-five feet long and eleven and a half feet wide outside of the guards, and with crew and stores on board should not draw more than fonrteen inches of water. "The model below the water should be like the elongated bowl of a spoon, point forward, but with more fulness in the bilges, and the bow should curve upwards and forwards and 
be four feet wide at the gunwale. The frame-work should be of iron or steel; the planking of hull and decks of teak: and the honse and joiner-work of California red pine or Japan cedar." If a houseboat should be built with the details conforming to the outline and description above indicated it would doubtless prove a very satisfactory boat for the shooter. It is absolutely necessary for a houseboat to be of light draft, as the water in many of the creeks and canals is shallow, and if the boat is too wide or high it would be impossible for it to pass under the numerous bridges that span these little waterways which often lead to the best shooting grounds. Such a houseboat would afford room for a large enongh cabin for sleeping berths and for sitting and eating purposes, bath and toilet-room, cook house and pantry, and dog kennels,-all the apartments to be arranged, apportioned and fitted up according to the judgment and taste of the owner.

After the houseboat has been furnished to please the owner or occupant, the greatest care should be exercised in the selection of 
a crew, and the important member is the loadah, the captain of the boat. The pleasures of a shooting trip may be wholly destroyed by an incompetent or unwilling crew, and when the loadah refuses to enter into the spirit of the trip and proves stubborn the annoyance becomes exasperating. Perhaps the better way of dealing with an incorrigible loadah is to stop the boat, make him go ashore, and put some other member of the crew in command. My own experience is that on one occasion such action resulted in a prompt corrective to all future hindrances and troubles and the loadah was glad enough to have permission to return to the boat. In an interesting and excellent book entitled, "With Boat and Gun in the Yangtze Valley", the author, H. T. Wade, gives in detail the duties of a loadah, which show that the success or failure of the shooting laroely depends upon hin. A paramount qualification is that the loadah should have an accurate knowledge of the places where it is proposed to sloot and that he should know how to control his crew. Unless he possesses these qualifications his efficiency in other respects will be at a large discount. 
Of the duties of a loadah, the one ever present is the careful management of the boat and her preservation. Without this attention the boat may be damaged in the narrow waterways or by collision with the native boats which, it would seem, fill every stream as the carriers of the internal trade and commerce of China. The management of the boat also means that the loadah should be ready at short notice to go from place to place, and if familiar with the tides and currents he will employ the means calculated to ensure the fastest movement. When there is a head tide or wind, sometimes it is necessary to "Yuloh" or "Track". Yulohing is nothing more than Einglish sculling, except that the oar in the former is fitted on a pirot, while in the latter it is worked in a hole the shape of a half circle. Under favorable circumstances the average rate by ymlohing is from $3 \mathrm{r} / 2$ to 4 miles per hour. When the wind or current is very strong ahead tracking is the more certain means of moving the boat expeditionsly. One end of a rope is made fast to the top of a bamboo pole which is secured near the mast about ten feet above the deck, and several 
of the crew go ashore with the other end and pull the boat along at the rate of 3 miles per hour. When the wind is fair and the nature of the waterway permits of course the sail will be hoisted and unfurled to the breeze.

If the shooter begins his shooting trip from one of the open ports he will usually be able to engage a steam launch to tow his houseboat many miles inland. At Shanghai there are several launches with regular schedules and runuing as far into the interior as the depth of the water in the creeks and canals will allow; and by means of the tow launches the shooting grounds can be more quickly reached. The usual hour for leaving Shanghai is $40^{\prime}$ 'clock in the afternoon and, as a rule, the houseboat may be unfastened from the lanuch the following morning and her bow pointed up sone stream that empties into the main waterway, but too narrow or shallow except for the houseboat I have described or some small cargo boat. But now houseboats are being built and fitted with gasoline or kerosene engines and the boats thus constructed are proving satisfactory. Soon the 
houseboat propelled by yulohing will be numbered with the hammer gun and live only in the memory of the old sportsmen who, when China was first opening her ports to the westerners, were so often glorious in the enjoyment of their sport and, when "up country", "over all the ills of life victorious". The commissary department is important, but the shooter should know what he likes to eat and drink and provide himself accordingly.

Gun: If the shooter intends to liunt for big game he will of course understand that he should have a rifle of the proper caliber and such a one he can easily select, as there are several first class makers who will advise and fit lim from long experience. The rifle is undoubtedly the king of small fire arms, for with it the farmer defends his fields and flocks against the ravages of wild beasts and with the same weapon the patriot establishes and maintains his personal liberty and the legal enjoyment of his property. But it sliall be my aim to describe the kinds of shot guns the shooter will be likely to find more useful during his shooting expeditions in China ; and in connection 


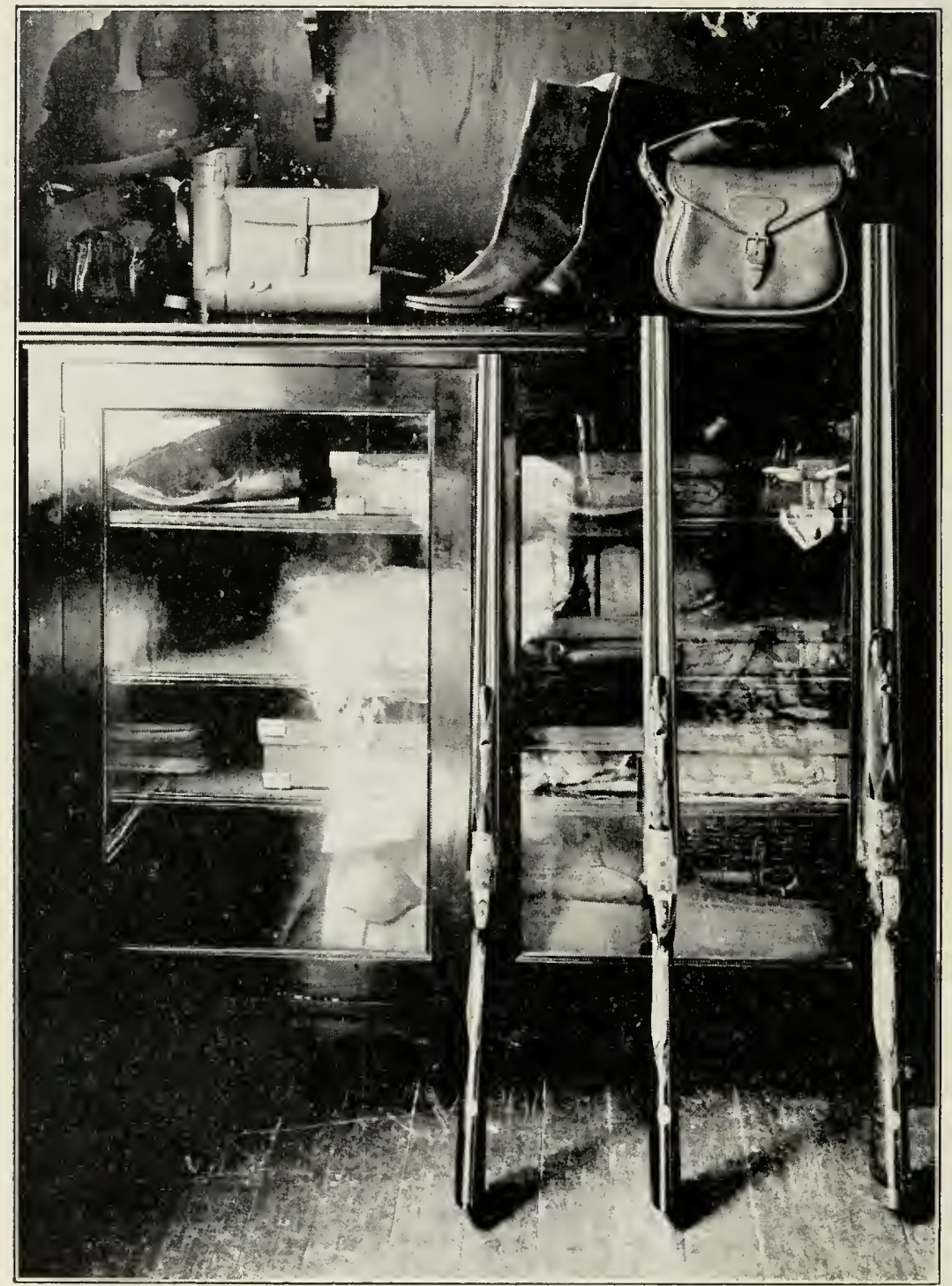

FAVORITE GREENER GUNS. 
with the subject I venture to believe that my reader will not object if I indulge in i brief description of the gun, as fashioned many years ago, by the most skilfull gunbuilder the world ever produced. The true sportsman has already anticipated me, for to think of a gun the name of Joseph Manton at once comes into the mind; and there is Peter Hawker the no less unrivalled sportsman. Shooting one day, in company with Manton, Col. Hawker writes thus in his fascinating diary: "Joe shot like an angel; he discharged ten rounds and pocketed his ten birds in brilliant style. What care we for all Europe." It takes a real sportsman to write like that, and, better still, to feel it.

It is doubtful if there is a living gunmaker of any note who will not readily concede that Joseph Manton was the father of the modern shot-gun. The guns built by Manton and which, for symmetry and balance, successfully passed the most critical examination were of the flint-lock pattern. It was on this pattern of a gun he would seem to have exhausted his skill in perfecting as nearly as art and invention 
would admit. There are a few of the fint-lock guns, single and double, built by Manton which, on account of their exquisite finish and proportion are treasured away in gilded cases as too sacred to be exposed in the field. The present day slooter would have to practice for sometime before succeeding with a right and left of a flint-lock gun, but Col. Hawker tells us that with sucli a gun he was successful with fourteen consecutive rights and lefts at partridges and fourteen consecutive single burrel kills at snipe, and because he shot with one of Manton's guns which lie was able to pitcl quicker than any other. Manton died in $\mathrm{IS}_{35}$, before the breech loaders and clioke bore cane into fashion, but if living his genius would no doubt enable him to hold the first place in his profession as when he was the acknowledged head of all gummakers. In bend and sliape the modern gun is similar to that of a Manton's, which proves that his fertile and inventive mind was far ahead of his time in knowledge as to how a gun should be shaped in order that the shooter might pitch it quicker and with nore comfort. It is interesting to read the opinions of this 
muaster of gun building as they are written by Hawker in his diary. "The late Joseph Manton", says Hawker, "who knew more about a gun than any man in Enrope, assured me, after innumerable experiments, he has proved that two feet eight for a twenty four guage barrel is the best proportion for a sporting gun". 'There slionld be plenty of metal near the breech end, adds Hawker, not only for strong shooting but for good elevation; and the barrels should be tapered like a bulrush, no hollowing out as this injures their shooting. One of the most skilfull barrel borers of his time was named Fullard, whose barrelnuanufactory was in Clarkenwell, and Manton did not hesitate to admit that Fullard could bore the best barrel for duck shooting. When Manton lived, writes Hawker, "in those days we had but one gummakernow they are all-all gummakers !!!"

The sportman will be interested in a nore detailed description of a Manton gun. One is described as follows: "Stub twist I4 bore $291 / 2$ in. barrels, with flat top rib. The stock is well bent, $I 5 / 8 \mathrm{in}$. at comb and $21 / 2$ in. at heel; the length $14 \mathrm{r} / 2 \mathrm{in}$. and the gun 
weighs $7 \frac{1}{4}$ lbs. The locks have an ingenions arrangement to effect the alteration from flint to percussion or vice versa. The flasli pans are pivoted and carry nipples on their rear faces. They can be secured in either of their dual positions by neans of thumbscrews passing through them and engaging on pivots. By slackening these screws and turning the flash pan pieces about oneeighth of a circle forward the nipples are brought into position to be struck by the recess shoulders of the cocks. The touchholes and vents are gold lined, and the gun is lightly engraved with a bold scroll ornainent."

Another gun by the same maker is one originally flint and altered to percussion by new pivoted pieces carrying nipples replacing original hammers and new cocks. "Stub twist 20 bore barrels, $30 \frac{5}{16}$ in. in length. Bend of stock I $5 / 8$ in. $2 \frac{1}{4}$ in.; length $143 / 2 \mathrm{in}$. The gun weighs $53 / 4 \mathrm{lbs}$. The butt of stock is thickened towards the toe, and the combs of cocks are very short."

Another of Manton's guns appears to 
have been intended as a flint lock when begun on and was altered to percussion in the course of manufacture. "The cocks are flat with blued steel let in the noses. 'The nipples are set in rare ends of breeches, but the lock plates are cut away as for flint. Stub twist 15 guage barrels, 293/8 in. long; bend of stock, $11 / 2-21 / 4$ in. ; length of stock, I $43 / 4$ in. ; weight of gun 6 lbs. I I ozs."

The genuineness and the accuracy of the descriptions of the above guns are vouched for by the highest authority; and one more by this celebrated maker may be added: these are a pair of bar lock percussion double guus. "Stub twist barrels $29 \mathrm{I} / 4$ in. 18 bore; length of stocks I $43 / 8$ in; bend at combs $13 / 8$ in ; bend at heel 2 in ; the pair weighs 6 lbs. each."

It has been observed that Manton was not an extremist either in the length of the barrel or the bend of the stock, but shaped bath on medium lines, which experience has attested as wore effective for a sporting gun. There is but one of those described the bore of whicl is similar to that of a gun now in use, a twenty bore, with barrels a fraction more than two inches longer than 
the standard length for a twenty bore gun of the present day. The 1110st effective twenty bore gun I ever owned had barrels thirty two inches long and was built for ne by W. W. Greener as a special order.

An opposition as earnest was offered when it was proposed to substitute the hammer gun with percussion cap for the flint gun as was manifested to the introduction of the liammerless gun. The flint gun was put aside with the greatest reluctance and apparently with genuine grief by some sportsmen. Col. Hawker gives vent to his feelings in nninistakable language and takes the occasion to remind the gunmakers that since the death of Manton they were withont a king. "The gunnakers in short, still remain as I left them like the frogs without a king; and, as before, complaining bitterly about the dullness of trade. But for this they have to thank their introduction of the detonating system, by which they got canght theniselves in the very trap that was laid for their customers. When fint guns were the order of the day, few sporting gentlemen of distinction ever thought of using anytling but the gun of a first rate 
maker, for the simple reason that on the goodness of the work depended the quickness in firing, and consequently the filling of the bag. But, nowadays, every common fellow in the market-town can detonate an old musket, and make it shoot as quick as can be wished; insomuch that all scientific calculations in slooting, at moderate distances, are now so simplified that we, every day, meet with -Jackanapesapprentice boys who can shoot flying and knock down their eight birds out of ten."

But Col. Hawker was too public spirited to be insensible to improvements in mechanical science, and while he loved his flint gun as an early companion he adinits that later on he was kidnapped into using a detonator. He writes: "The detonators have, of late years, been much improved in shooting in consequence of their being bored different from flint guns. They now detain the shot longer in the barrel, in order that the powder may have tine to kindle, which is done to such a degree as to occasion an increase of recoil, and a liability to becone "leaded" with much firing. Many waddings have been invented to counteract this, 
but still none of them will make a detonator, of equal weight, shoot quite so strong and regular as a flint gun. Though, like the rest of the sporting world, I have long been kidnapped into the constant use of detonators, still, were my time to come over again I might probably be content with the fint." Notwithstanding Col. Hawker yields in favor of the detonator he tenaciously adheres to the opinion that the flint gun is his choice for heavy wild fowl shooting. He arrives at this conclusion, and says: "from the results of very many experiments I am of the opinion, that for neat shooting in the field, or covert, and also for killing single shots at wild fowl rapidly flying, and particularly by night, there is not a question in favor of the detonator, as its trifling inferiority to the flint is ten fold repaid by the wonderful accuracy it gives in so readily obeying the eye. But in firing a heavy charge among a large flock of birds, the flint has the decided advantage. Moreover, the sudden and additional recoil of a detonator, with the full charge of a duck gun is apt, if the sliooter be not careful, to strike the hand back and give him a severe blow on the nose." As 
Joseph Manton was the king of gummakers and Peter Hawker the prince of sportsmen an apology will not be required for describing some of the guns built by the former and giving a few extracts from the opinion of the latter on the subject of shooting. Whether the shooter of the present day reads Col. Hawker's notes with approval or disapproval a large majority will agree that lie was sound in his opinion as to the requisites of a first rate gun. He writes, that there should be "( I ) soundness and perfect safety in guns, (2) the barrels correctly put together for accurate shooting, (3) the elevation being mathematically true, and raised strictly in proportion to the length of the barrels, (4) the stock properly cast off to the eye, and well fitted to the hand and shoulder." It is strange that such a sportsman as Col. Hawker shonld dismiss another very essential requisite of a gun in these words: "I say nothing of the balance, because any good carpenter, with some lead and a center-bit, can regulate this to the shooter's fancy." There are few shooters who would purchase a gun unless properly balanced by the maker, and there is not a first class gunmaker who would allow one of his guns 
to leave his shop that did not balance iu every part. If there is too much weight at the end of the barrel it can be counteracted, as Col. Hawker says, with some lead and a center-bit, but the counteracting lead should be evenly distributed or the stack will feel nuduly heavy in certain parts, and the best skill of the gunmaker is required to correct deficiencies in the balance.

I repeat, that if the shooter intends to hunt for big game he will provide himself with a rifle of suitable caliber, and he will know that for shooting tigers and bears a rifle of larger caliber onght to be used than would be necessary when hunting for deer. And the bore of the shot gun will also depend upon the kind of small game to be lunted. If gunuing for suipe, quail, partridges, or woodcock a twenty bore gun, if skilfully bored, will prove an efficient weapon, and its light weight commends it to those who are not physically strong. My own experience is that a twenty bore is more effective when loaded with No. 7 shot. It will shoot No. 5 or No. 6 shot with reasonable effect, but with No. 7 the shot are more evenly distribnted, and this is the 
number I would advise to use when shooting woodcock and partridges, while for sinpe and quail I would use No. 8 or No. 9, perhaps the latter. This bore of gun is too small for pheasants and wild fowl and often proves disappointing when used on that kind of game. The sixteen bore was a very popular size at one time, but now when a snaller bore than the twelve is preferred I would make choice of the twenty. The standard length of the barrel of the twenty bore gun is 28 inches, and that of the sixteen bore either 28 or 30 inches long. But the bore which is now almost the universal choice of the shooter for field shooting, and which is the recognized standard, is the twelve bore. 'The length of the barrel should not be less than 28 inches, nor nore than 32 inches. Those who have exper:mented with the twelve bore and tested its shooting capabilities give it as their opinion that a barrel 30 inches long is the required length to bring out the highest shooting capacity of this bore of a gu11. The weight of a twelve bore should not be less than 6 lbs. nor more than $7 \mathrm{I} / 2 \mathrm{lbs}$. When of the former weight I oz. of shot is enough, but when of the latter $\mathrm{I} / \mathrm{s}, \mathrm{Oz}$. is a deadlier load. 
Ordinarily No. 6 shot is the size mostly used for the twelve bore, but when the gun is of light weight and the shooter has a steady hand and quick eye I would advise him to have his cartridges loaded with No. 5 shot, as with this number there is less strain and recoil. The heavier weight of this bore of gun, when full choked, is an excellent wild fowl weapon. It will shoot No. I shot with remarkable accuracy, and I have shot geese as far off with my heavy weight twelve bore, loaded with $3 \mathrm{r} / 4 \mathrm{oz}$. of swokeless powder and I $1 / 4$ oz. No I shot, perfect brass case, as I have with my eight bore gin. For an all round wild fowl gun I would select a twelve bore, full choked, and weighing about $7 \mathrm{r} / 2$ lbs.; for the field, and general shooting a light weight twelve bore, $1 / 4$ choked would be my choice, and I would have my cartridges loaded with 3 drm. of swokeless powder and I oz. of Nos. 5,6 or 7 shot. When the season is late a pheasant is quick and strong and No. 5 is the best shot, but in the early part of the season No. 7 is large enough. From some canse I never cared to use a No. 6 shot, and I an unaccountably prejudiced against all shot of an even number. If the shooter 
expects to hunt wild fowl as a speciality he should by all means provide himself with an eight bore gun, a four bore being too heavy and unwieldy as a shoulder gun. The eight bore should be full cloked upon the most scientific principle. Some prefer the ten bore gun for wild fowl shooting, but this bore appears to fill a place between the eight and twelve bores similar to that of the sixteen bore between the twelve and twenty. If the twenty bore is too small the usual drop is to the twelve and from a twelve it is better to go to the eight. The eight bore is built with barrels of different lengths, and each length has its champion, but the standard length for the barrels of the eight bore is $36 \mathrm{in}$; the medium length is $34 \mathrm{in}$. and the proper minimum length $32 \mathrm{in.}$ Sometimes the barrels are longer than 36 in. and even shorter than 32 in., but it is advisable to adhere to recognized standard lengths. I have shot with barrels $36 \mathrm{in}$. and 34 in. and with the sane effectiveness. The middle weight eight bore weighs about I 3 lbs, the nuaxinum abont I $5 \mathrm{lbs}$, and the minimum about in lbs. The load should not be less than $6 \mathrm{drm}$, of smokeless powder and from $2 \mathrm{oz}$. to $2 \mathrm{r} / 2 \mathrm{oz}$. of shot. 'The heavy 
weight eight bore will shoot $7 \mathrm{drm}$. of sw1okeless powder and $23 / 4 \mathrm{oz}$. of shot without unpleasant recoil. It is not efficient to nse for an eight bore shot smaller than No. 4 , but this gun, whether of the maximum or minimum weight, does its best work with No. I shot. If the ten bore is the shooter's favorite wild fowl gun then let him use that bore and he will be better contented than if he allows the opinion of another to influence his choice. It contributes wonderfully to success in the field when one carries the gun of his clioice and has confidence in his cartridges. The shooter has already concluded as to the bores of the guns I would advise him to select for small game shooting. He will find the twenty bore a most useful little weapon at odd times, and specially for afternoon shooting when fatigned by his morning shoot; the twelve bore is indispensable, no prudent sportsman will go to the shooting grounds withont it; there is no other gun that will fill so many requisites as this bore, and as it is built of light or heavy weight one of each might be taken along if not too great a charge. The next in order is the eight bore, and with the twenty, the 

twelve and the eight bores the shooter will be most efficiently equipped. It must be understood that I am advising the shooter to equip himself with double barrelled hammerless guns and automatic or nonautomatic as he may prefer. A full medium price gun would prove less liable to get out of order and generally more satisfactory.

Dog: The four dogs in general use in China are retrievers, spaniels, setters and pointers, and "what is the best kind of dog for sporting purposes" is a question to which various answers have been given. My own dog is a half-breed German pointer, medium size and liver colored. I have shot over him for five years, and he has always borne himself intelligently in the field. He is now eight years old, slightly deaf, eyesight somewhat inpaired, but otherwise strong and still useful. On this particular subject I know of no authority more competent to instruct than my friend H. T. Wade, an old sportsman in China, a close observer and whose opinion is based on long experience. The following quotation is from Wade's book entitled "With 
Boat and Gun in the Yangtze Valley."

"Retriever: It will be only necessary here to take note of one kind of retriever, the black, flat-coated kind, for the objection that may be raised aganist him can only be intensified when applied to the curly-coated description.

"Adnitting to the fullest tliat a retriever is a wonderfully sagacious dog, and that he is capable of affording lots of sport, yet the following objections may be found to weigh against hin and long haired dogs generally.

"In the first place, rheumatism is by no means an uncommon complaint in China, and no animal renders itself more liable to this ailment than one that is difficult and troublesome to dry. A dog has to negotiate a lot of "water business" in the course of a day's shooting in these provinces. He often returus to the boat wet, only to be turned over to the tender mercies of a coolie, who performs the essential duties of drying and grooning in any but a thorough manner; so that the animal not only may be sent to bed wet himself, but be an active cause of discomfort to his kennel 
companions. Besides, retrievers generally hold so much water in their coats as to render themselves a perfect nuisance when crossing creeks in sampans or dinghies. Further than this, the very nature of their jackets renders them specially liable to collect the grass and other seeds, "fruitful cause of so much woe." Finally, retrievers from their size and weight constantly fund themselvesin trouble when working brambly cover; are invariably clumsy in their attempts at extrication from tangled beans and similar crops; and, as a rule, are not only slow in setting to work to bring back a wounded bird, but slower still in returning with the quarry. Such are the more prominent objections to this class of dog.

"Still, should a sportsman elect to have a retriever in this country, he might with advantage have regard to the following simple points:-The dog's coat should be jet black and lie very flat, no curl whatever being admissible. The head should be long, with a squarish, not a pointed muzzle, the ear small, the neck "airy," and the tail carried below the level of the back. Above all he should stand low. 
"Spaniels:-By far the most numerous class of sporting dogs in China are the spaniel descriptions. They run in all sorts of shapes and sizes and colours, and for the most part are of the most mixed origin. Seldom is a really well-shaped spaniel seen out here, less frequently a well-broken one. In the open country they are of but little use, as the speedy pheasant can easily run away from them; in a cane-brake they are not big enough to get over or strong enough to force their way through the thick tangle which lies at the foot of the cane stalk; and it is seldom that one connes across a dog that will work a copse in anything like systematic manner. Still, if spaniels were taken in hand early, were tanght to work the covers properly, and restricted to that particular kind of shooting, it might be just as well to own one. A brace of busy well-broken spaniels is a pretty sight, no doubt, but one quite unknown in these parts. Yet should the sportsman determine on a spaniel he would probably be on the right track if he secured a dog with some of the unmistakable Clumber strain in lim. Clumbers are slow, but they are pretty sure and very 
strong, and being flat-coated,-for any curl is indicative of a cross, - are better adapted for working undergrowth than any other kind of spaniel; and the bigger and heavier the dog the better, for a three-pound fluttering cock pheasant is no mean mouthful. Other great drawbacks to spaniels are that their long ears and full coats are certain seed-traps, and require a large amount of care to keep clean and dry.

"Setters:-From time to time some capital setters have been seen in Chinahandsome, well-bred and in some instances, well-broken dogs of nearly all the recognised breeds-Laveracks, Llewellyns, Gordons and Irish; of the last two kinds Shanghai can still boast of some good examples,"surpassingly beautiful," as Idstone enthusiastically describes them. In a less degree, because his coat lies flatter, but still to some extent, the same objections that have been advanced against the retriever and spaniel apply to the graceful setter. Seeds will find their way into his feet and ears and armpits, and the thick hair between his toes; and when it is remembered that one cruel grass seed between the toes is 
enough to lame a dog, and one seed in the ear quite sufficient to set up an annoying cankerous discharge, the reasonableness of not shooting over a valuable animal until the seeds have been rendered harmless by the frosts should be willingly admitted; and if one's setter is only to be available for shooting purposes for a couple of months in the year at most, the question of expense alone is one worth a passing consideration. One point in favour of setters is that they are hardier dogs than pointers, especially the Irish dogs, and they are certainly more companionable.

"Pointers:- The preceding objections have been raised not against the virtues of the dogs enumerated but against the unsuitableness of their coats for work in this climate until the cover lightens and the seeds are down. Something may be done towards mitigating the seed evil by working the dogs in cankercaps, but still their necks and feet are ever open to the reception of the fell annoyance. Now, pointers may be said to go harmless through these trials: seeds very seldom get into their ears, and are without much difficulty extracted from 
their feet, while the "set" of the short hair of their coats is not favourable to their lodgement.

"What seems to be required for shooting throughout a season is a strong, wellbroken, but, perhaps, not too highly-bred pointer: one that will take the water, face the thick covers, and possibly retrieve; and there are such dogs in the place. The coats of some setters lie very flat, and they are the next best dogs to pointers; but the long-haired varieties, all good and useful in their way, had better not be taken up-country until they can work the covers with inpunity to themselves. A sentimental objection to pointers is that they are not so companionable as the other breeds, which is true to a certain extent; but it must be remembered that when a pointer is on business he means business, and that is exactly what he is wanted for. In choosing a pointer, always try to get one with sloping shoulders, long, airy neck, a deep but not broad chest, and a loin, arched, very wide, strong and inuscular. Some useful pointers occasionally arrive here from Germany. For the most part they are well educated 
and good at retrieving, but they run big and heavy, and are too much given to "pottering." A last word may be said in favour of the pointer: he can be worked from the beginning to the end of the shooting season, whereas it is little less than cruelty to take a spaniel or a setter out before December.

"If the foregoing considerations are anything worth, the reasonable answer to the question this chapter commenced with is that the pointer is the best dog for shooting purposes in North China."

Clotlies: The condition of the weather will suggest the thickuess of the clothes that should be worn. The color is very important and must conform to the color of the landscape. A shooting suit of some liglit brown color will, as a rule, meet the requirements at most any time of the season. The hat or cap ouglit to be of a similar color to the clothes; I prefer the hat with a soft crown and rather a stiff brin as being a better protection to the face and back part of the liead. A cap, of course, may be made to cover the back part of the head, but then it interferes more or less with the ears 
which should be uncovered and alert when shooting in the field. It is a mistake to be indifferent to the fit of the shootiug clothes; they should be fairly loose, not baggy, but should fit. The shooter will shoot better when he feels that his clothes, like his gun, fit easy and comfortable. My choice for foot wear is a boot and leg of the same piece of leather, the leg as high as the large part of the calf. The boot thus made can be put on and off withont the trouble of unlacing or unbuckling which is a nuisance sometimes. Most of the boots for shooters are too heavy and become tiresome to the wearer. The sole ought to be just thick enongh to protect the botton of the feet from being bruised, and lave soft iron nails set well apart; steel nails will slip on the rocks. It is probable that no one of this day has given as mucli attention to the equipment of a shooter as Sir Ralph RayneGallwey, and I will quote what he writes with reference to clothing, reserving the opinion, that as the slooter acquires experience he will equip himself as conduces most to his comfort. Sir Ralph writes: "For hard work on the hills a flannel sliirt should be worn. Tweed shooting jacket, 
with plenty of pockets covered by flaps, otherwise things drop out in crawling, especially when going down hill. Waistcoat, with four pockets, one inside for the watch. Knickerbockers loose, as they dry 111ore quickly, and when wet are less uncomfortable. They should be double at the knee, and made long enongh to meet the hose when required, or the midges will dine freely. Cap close fitting so as to show as little as possible above the head-this is most inportant as shelter against sun and rain. A plaid or short cape or cloak which should be waterproof, color, neutral tint, not too dark, but also not very light. The coior should be adapted to the aspect of country and the ground. Stockings of strong worsted; the shoes or boots should be strong and not too tight-fitting. They should have soft iron nails set well apart; steel nails are most dangerons, as they slip on the rocks. To prevent blistering soap the stockings well in the morning for the first day or two."

In a chapter on the dress of a shooter, written in 1844 , Col. Hawker expressed the hesitation of writing anything on the sub- 
ject at all, lest his book should fall into the hands of some philosopher who might censure him for introducing so frivolous a subject; but it gives the following advice: "We all know that a jean, nankeen, or any" kind of thin jacket, is the pleasantest wear for September, one of fustian for October, and one of velveteen for the winter; and that for a man who, at all times, uses but one kind of jacket, fustian would be about the medinm. That called baragan fustian is by far the best and most useful. After having tried almost everything that is commonly used, and some of the wretched articles that are pulped by advertisement, I have found nothing better for a light summer jacket than what is made at Manchester by the name of satteen, jeanet, or florentine, which is printed on each side in imitation of cloth. This stuff far surpasses the others for lightness, comfort durability, and everything that can be required for warm weather; but as there is no particular interest in making it-rather the reverse, it is most everywhere very easily procured; so that your tailor would probably be obliged to order it, in doing which he cannot choose it of too good a quality. 
With regard to the other parts of the dress, but few persons appear to know what is really comfortable, and I 1nay, therefore appear singular for considering as most uncomfortable that which is commonly, and was till of late years universally worn: I mean shoes and gaiters. To say nothing with being tormented with two or three dozen buttons every morning and having your ankles and knees in a state of confinement through a hard day's exercise, it need only be observed that, if you step in the least puddle, you are wet; if you tread in moist ground your sloe is pulled down at the heel; and you are often liable to be annoyed by your shoes untying, and thorns and little bits of stick, etc, getting into them or between the bottoms of your gaiters. How inuch more comfortable, then, is the dress here recommended? With lambswool stockings and flannel drawers, put on a pair of overall boots, and then draw over them a pair of tronsers, which milay be made either of fustain or leather, and so strongly defended inside the knee, that no thorn can penetrate. Thus you are equipped withont trouble or loss of time; you have your muscles perfectly at liberty 
for hard exercise, and are free from every annoyance."

Being a true sportsman, Col. Hawker has the reputation of experimenting practically and intelligently in all matters connected with shooting and his views are interesting if, in some instances, they are not approved by the sportsman of the present day. The last edition of his book which went to press under his own supervision is the ninth and bears the publishers' date of 1844 . 

SMALL GAME 



\section{CHAPTER III.}

SMALL GAME.

China has long enjoyed the reputation as a field offering to the sportsman the opportunity of making a bag of small game of a vastly varied nature. But this might not have been the situation had that great wave of sportsmen which swamped the prolific shooting centres of Africa and of India done other than but lightly touched these more eastern shores. Happily shooting in China for many years past has been comparatively free from the visits of the wandering foreign sportsman; but unhappily sport is now seriously threatened by the foe within the gates, for it is impossible to believe that small game can long withstand the organized raids of the countless numbers of those who now go a shooting. There are others far greater, numerically, than the Anglo-Saxon; the Continentals and the Japanese, who can repeat the reputed old dictum, "Here is a fine day, let us go and kill something." Unfortunately this "fine day" of theirs occurs both in season and out of season, 
and but too frequently in the latter of these periods. And so the regrettable fact is indisputable that the visible game supply grows markedly less and less, and when a few more years shall have rolled by it is conceivable that it may be said of shooting, from which category the migratory birds must, of conrse, be eliminated, "the glory has departed."

China is, and possibly for all time, will be the congenial home of an infinite variety of both flying and ground small game; but the China best known to the foreign resident is limited to those districts which are within the compass of the treaty ports.

Plieasants:-In writing of the small game of China one's thoughts naturally and instinctively turn to the fanily which is at once the most numerous and most prolific, the Pliasiandae.

According to the highest known authority on the subject, Dr. Bowdler Sharpe, of the British Museum, there are some seventeen different kinds of true plieasants, of which the following are common if not peculiar to China :- 



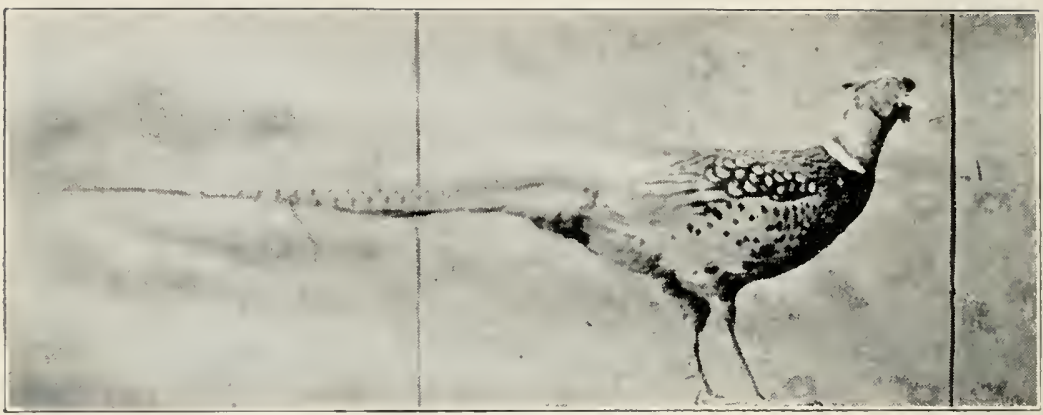

RINGED-NECK PHEASANT.

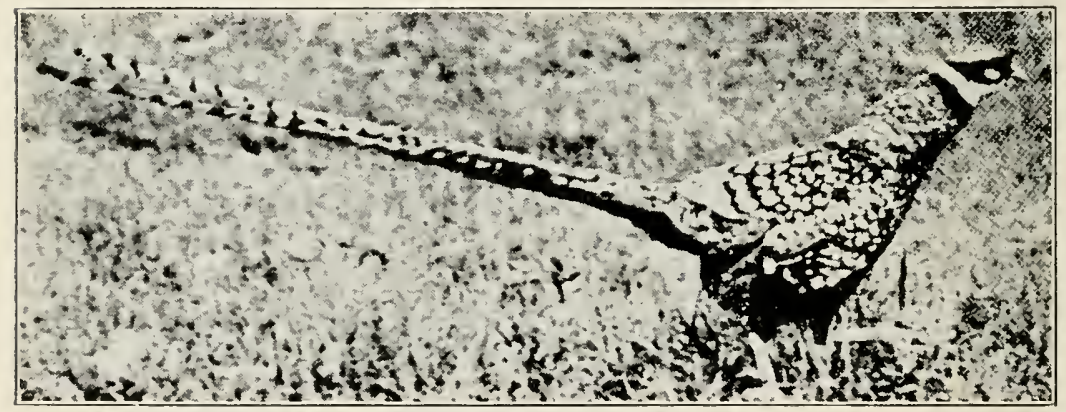

RELVES' PHEASANT 
The ringed-neck pheasant (Phasianus torquatus.) The ringless ( , decollatus.)

The Golden (Chrysolophus pictus.)

Darwin's

Reeves'

Strauch's

Stone's

Elliot's

(Phasianus Darwini.)

Lady Amherst

"

"

"

,

,

,

,

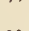

Reevesi.)

Strauchi.)

elegans.)

(Chrysolophus Ellioti.)

The ringed-11ecked or collared pheasant is the bird so faniliar not only in China but in England and America. Food, shelter and water are the sine qua non of a pheasant's existence, "and where these do most abound there the pheasant will be found." As far as north and ninid China are concerned birds are found in greatest numbers on the rich grain lands watered by the Whang-Ho and Yangtze rivers; and a similar condition possibly prevails in the valley of the Sikiang or West River in the south. But the pheasant by no means confines itself to the plains, a fact recognised by the Chinese themselves who, in the mountainons regions, term it the San Chi or hill fowl. However, wherever net with, the pheasant always affords sport, for it possesses all those qualities, pluck, strength, cunning and speed which command the 
strictest attention to business on the part of the shooter. In what is called the "pairing" season the cocks are very pugnacions, and so intent at tines are they upon their battle that even in the open they niay be approached with comparative ease. When the "spring" love is over the male is nothing loth to enjoy the alluring amenities of the inviting farmyard. There is no grolden rule in pheasant shooting, but he who would hope to be more successful than his neighbours should have some knowledge of woodcraft which is the main secret in shooting, be in something like fettle, keep an equal temper, taking alike the bitter and the sweet, and above all things hold the iron straight. The China pheasant is by no means a difficult bird to shoot, though it is often an uncommnnly difficult bird to recover; for, once on the ground, it soon gives ocular demonstration of the possession of such powers as the speed of the greyhound, the donbling of the hare and the artfulness of the fox, while if hard pressed it will take to the water and swim, nay even dive, like a duck. As for dogs, time was when reason suggested, for a variety of causes, that pointers 



$$
1
$$


were the animals most likely to show sport. In the changed condition of things, when cotton fields in interminable continuity are the order of the day, at least in the provinces of Anwhei, Chekiang and Kiangsu, and the sound of the foreigner's heavy footfall is almost telephonically communicated to the listening and expectant pheasant which, forewarned, has ample time to make itself scarce, the question arises, and is worth some consideration, whether better results would not be obtained if the fields were walked through by sandal-shod beaters, the guns, well ahead flanking them, and the coverts worked by a persevering spaniel and for that nuater the larger the animal, the better.

The Chinese ringless pheasant, whose habits doubtless are very similar to those of the ringnecked variety, is chiefly found in that mountainous region which has its northeastern extrenity in southern Shensi, and its most southerly in western Yuman.

The Golden pheasant affects that portion of China from Ichang on the Yangtze to the west of Chungking. It is also said to have been met with as far east as Shasi. Certain 
it is that many of these beautiful birds are hawked about the streets of Hankow, confined in small reed baskets opened at each end to allow freedom to the head and tail of the prisoner, and may be readily bought for a couple of Mexican dollars a piece.

Darwin's pheasant, comparatively rare, is to be net with in the Chekiang hills from Ningpo in the east to the monntainous country to the south of Kiangsi.

Reeves' pheasant comes from the province of Szechuen principally, though its range extends as far east as Wanshan in Anwhei. It is a bird unmistakable not only from its colouring but from the length of its tail, which normally is about five (5) feet, but abnormal lengths of over six (6) feet are on record. It was originally imported into England by Mr. Reeves, a nember of the old China frm of Dent \& Co.

Strauch's pheasant, very rarely seen by foreigners, is found in the province of Kansuh to the extreme north west of China ; also of ten at a lieight of 10,000 feet above sea level.

Stone's pheasant. There is no record 


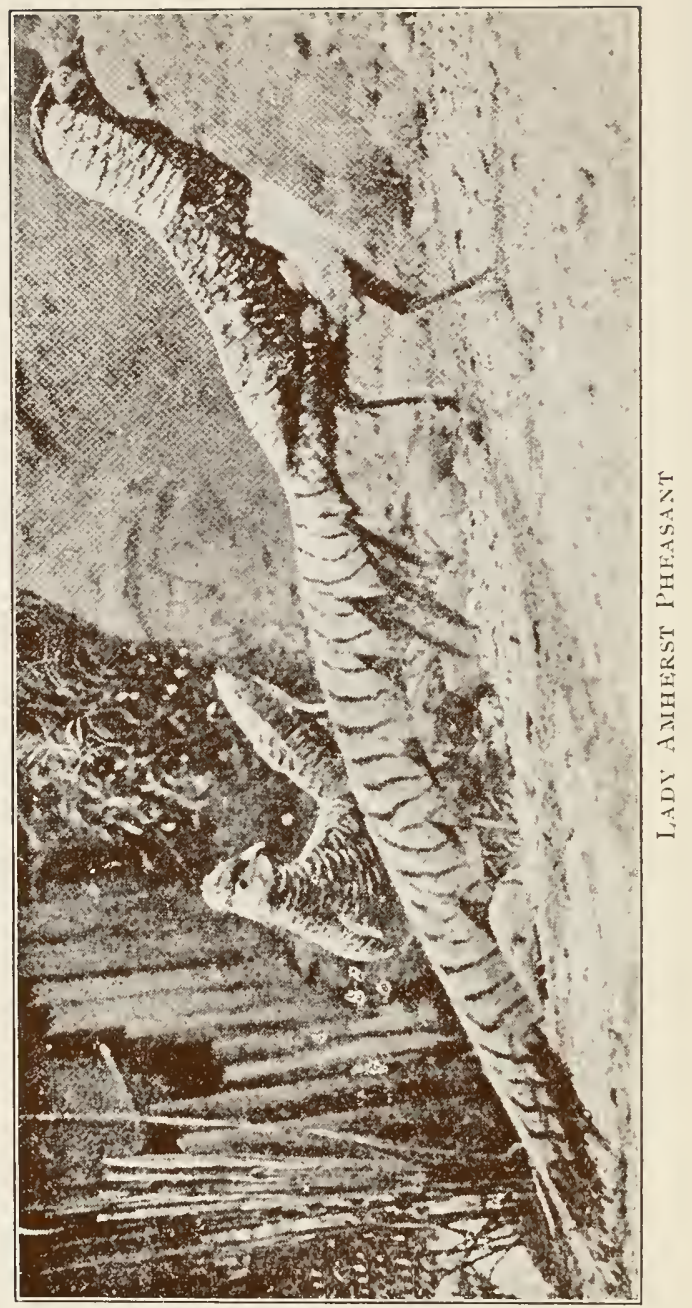


existing of its habits, but the bird is found in western Yunnan and western Szechnen.

Elliot's pleasant. 'This truly magnificent bird was first discovered by a former British Consul, the enthusiastic naturalist, Mr. Swinhoe; after whom the large migratory snipe is named, in the mountains to the back of Ningpo. Subsequently it was met with by Pere David, the eminent priest and naturalist, in the liils to the west of Foochow. "Like the Silver Plieasant it lives in the wooded mountains, and is far from common, being constantly on the move, and sometimes remains away for whole years without revisiting its original habitat."

The Amherst pheasant. This is another beautiful bird and in the fastnesses of the mountains of western China happily finds itself beyond the range of the ubiquitous gunner.

There are besides two kinds of Tragopans or horned pheasants, which are occasionally on sale at Hankow. They are said to come from Szechuen and are really gorgeous birds. To the tongue of the Hankow dealer rise as glibly the words "from Szechuen" in 
reply to the question whence the birds came, as does the stereotyed phrase "from Pootung" to the lips of the Shanghai salesinan when asked the source of his supplies. The two descriptions of Tragopans best known in China are those naned afier 'Temminck and Cabnt. The former are found in "southwestern and central China, extending from the Mishmi hills through Szechuen to sonthern Shensi and Hupen". The range of the latter is southeastern China, and the Folien mountains where it is said to be fairly abundant.

Detailed descriptions of these China pheasants will be found in the various natural histories. Particularly happy in descriptions and illustrations is the edition published by Edward Lloyd, Ltd., London.

Bamboo partridge (Bambuscola thoracica): This bird held in such high esteem as a table luxury, and spoken alliteratively of as "the table's toothsome tit-bit" is neither a partridge, a francolin or colin, but partakes of the characteristics of all three. It is not a partridge for its flesh is white and not dark, it is found in the thick covert and in the open, and it usually, but not invariably, 



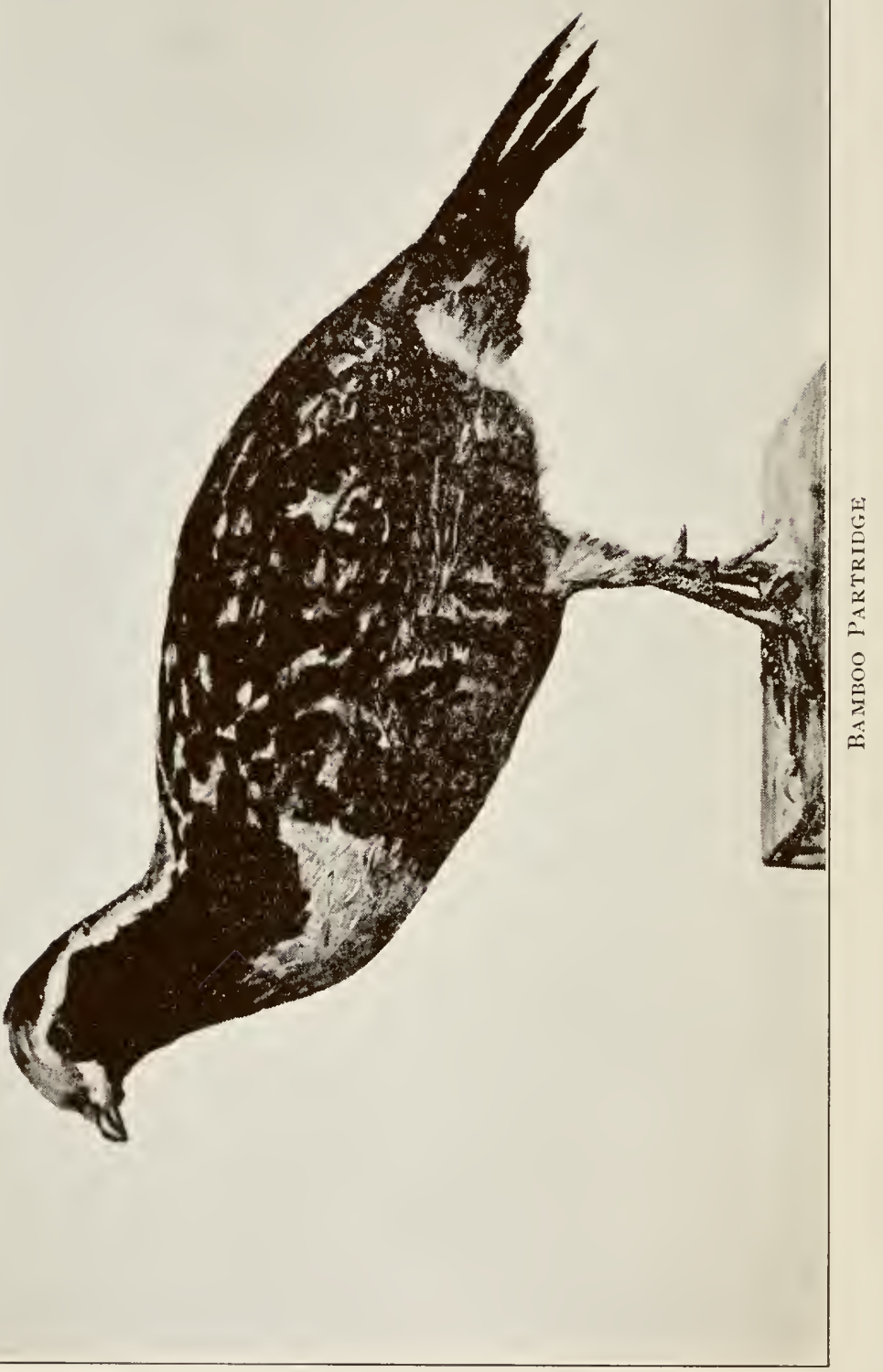


roosts on trees. Again, it is much larger than any of the American colins, with the white collar less distinctly developed. In the northern part of China, to which it seems limited, this appreciated bird is ordinarily found in small coveys, though as many as fifteen have been connted in a single covey in the pine and bamboo copses and frequently in the high thick flag grass so often to be met with on the borders of the creeks. A covey will run unseen before the guns for an incredible distance, but when pushed to an extreme will flush suddenly in all directions, affording what has not been inaptly describ. ed as a pyrotechnic display. But should they rise in the wood itself they will be very likely to settle on the branches, on which they crouch so closely as to make discovery very difficult. Sometimes, however, this wily little bird is caughe napping, and as many as a dozen, squatting on the espaliered branch of a Magnolia, have been known to fall when the smoke from a single discharge has cleared away, - an unsportsinanlike massacre! When wounded the bamboo partridge utters a cry piteous to hear, and long to be remembered, if ever forgotten. 
Its food consists chiefly of grain, seeds, the smaller pulses and beans. The call note of the male in spring time is a lond piercing challenge which the natives take advantage of to catch them. "A countryman once showed me low it was done," writes Mr. Styan in the "Ibis." "We had two birds in separate cages, one of which he hid under a pile of brushwood. The other was released, and his challenge being answered by the hidden bird, the latter was soon discovered, and a fight ensued throngh the bars of the cage." 'The natives practise the call with success, and there seems reason to believe that as many birds are captured by the fatal birdlime as fall to the native gingal.

The partridge found at Foocliow and Canton is known as the Francolinus sinensis. It is a rather larger bird than its congener of the north, and is characterized by its distinct markings of black, white and brown spots. This bird once afforded good sport in the valley of the Min river. Possibly the present day sportsman located at Foochow is not so enthusiastic as was his predecessor five and twenty years ago. 
The Chefoo or Red-legrged partridge (Caccabis chukor) seldom falls to the sportsman's guns, though a good many find their way into the northern markets, whence they are largely shipped to the markets of Port Arthur, Dalny and beyond. It is a good sized bird and of the weight of an average hen pheasant. Its flesh is white and is considered a delicacy. 'The Chukor may be found in different localities from sea level to an elevation of 16,000 feet, as in Tlibet. It is of redder tint than the Indian specimens, and its chief habitat is some 30 miles W. N. W. of Chefoo at a considerable height on the nountain sides.

Pallas' Sandg̈ouse. (Syrrhaptes paradoxus). This genus is distinguished by having only three toes. Its pale sandy colour as much as its liabitat seems to have suggested its name. These birds are gregarious, and move about in large flocks, often traversing enormons distances in search of water. Some years ago a few of these birds used to find their way to the Shanghai market, but of late they have become an unknown quantity. Suinhoe tells us that "in north China great 11 mubers 
of these birds are sometimes caught after a snow storm, when they arrive in large numbers in search of food. Having cleared the snow from a patch of ground, the natives scatter a small green bean to attract the birds, and sometimes manage to catch a whole flock in their clap-11ets."

The Snipes of China are seven in number, and it wonld be difficult to furnish any further information than is afforded in Mr. Styan's valuable contribution on the subject to be found in the pages of "With Boat and Gun in the Yangtze Valley."

The winter suipe (Gallinago caelestis), identical with the bird of Great Britain and northern Europe generally, is properly so called for it lies scattered through the country thronghout the winter months, thongh its numbers are largely increased in spring and autumn. It is a smaller bird than the other migratory snipes, and may be easily recognised by its fourtecn ordinarily full sized tail feathers, which have gained for it the name of fantail in India. There is really no saying where this bird may not be met with, but its preference seems to be for damp low-lying patches of 
ground. It arrives in alinost countless numbers in north China towards the end of the month of February, particularly on the margins of such food supplying waters as the Si Tai, Tai Hu, Tai Nan Hu, Poyang and Tungting lakes.

Of the three descriptions of snipes known as Lathans (Gallinago Australis), the solitary snipe (Gallinago solitaria) and the diminutive Jack snipe (Gallinago gallinula), being so infrequently come across, it is scarcely necessary to make other than mere mention. Naturally the snipes which have most attraction for the sportsman, whether he be in the Malay Peninsula or China, are the two large sized migratory species known as Swinhoes' or the big spring snipe, and the pin-tailed or lesser spring suipe.

Swinhoe's snipe (Gallinago megala) is the larger of the migratory snipes, and may easily be recognised by its great size, its comparatively thick short bill, and its tail feathers which number twenty in all, that is, eight broad central and twelve comparatively narrow feathers, six on each side of the central fan. Its weight runs from 5 to 
$S$ or more ounces, and some of the larger well nourished specimens might occasionally be mistaken for woodcock.

The pin-tailed snipe (Gallinago stenura) averages a couple of ounces less in weight than the Swinhoe, and is of a lighter build generally. Its tail feathers are twenty six in number, ten comparatively broad plumes forming the central fan, and sixteen very narrow, very stiff, pin like feathers flanking it, eight on either side.

In the spring, that is from the middle of April till towards the end of May, both the above migrants may be fonnd in the fields of young wheat, beans and rape, as also in the short linsh grass wherever they come across it. In the antu1nn, that is in Angust and September, the birds largely affect the umbered buffalo grass, where they are a sure find towards sundown.

Splendid bags were wont to be made in days not long ago throughout the provinces of Chekiang and Kiangsi, when paddy and grass were more common than they are now. Today so much land is diverted to the criltivation of cotton that the birds presumably are compelled to seek their food in 



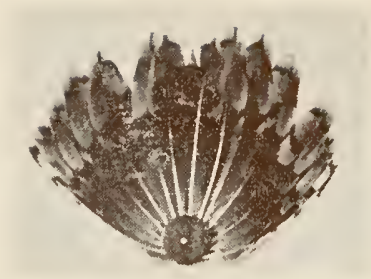

WINTER SNIPE, COMMON SNIPE:

SCULOPAX (SALLINAGO)

14 FICATHERS IN TAIL, ALI, ORIMINAY, BRUAY.

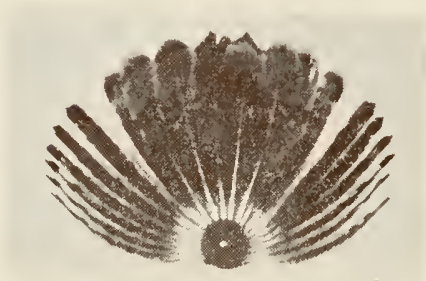

GREATER SPRING SNIPE, SWINHOH'S SNAPE

GALLINAGO MEGALA

20 FIATYERS IN TAIL, S CENTRAL, "RINARY, BROAI, OON EACIF SIDE, NARROW, STIFK.

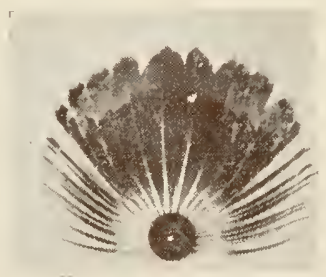

1,FSSER SPRING SNIPE, PIN-TAIIED SNIPE

GALIINAGO STENURA

26) FFATIULS IN TAll, IO CENTRAY, ORDINARY, BROAD.

$S O N$ EACII SIDE, VERY NARROW, STIFF. 
some more congenial soil beyond the radius of the foreign sportsman.

Snipes should always be approached down wind if possible. The bird, when not feeding, sits with its back to the wind, shoulders up and head depressed, and as the wind is all necessary for it to rise alertly and get underweigh it is obvious that the bird must then rise more or less in the face of the shooter and so afford a reasonably close shot.

But the great migration from the Russian Tundras in the north to the extremities of the great peninsulas in the south, Malacca, Burmah, India and Africa, goes on as it has done in time past and will go probably for all time to come: goes on in the same grand, irresistible, mysterious manner in spite of any changed conditions upon earth's surface effected by the hand of man.

"The birds of passage transmigrating come Unnumbered colonies of foreign wing At Nature's summons . . . . . . ."

The common woodcock (Scolopax rusticula) is a favorite but fitful visitant, uncertain as to the time of its arrival as in the numbers in which it visits. As a rule they 
arrive towards the end of October or early in November in the Yangtze valley, and are scattered thinly over the country throughout the winter. Some few birds probably remain and breed here, for cock have been sliot locally in May. A fact not to be lost sight of as regards woodcock is the undeniable persistency with which it yearly seeks its old resorts. From the identical corners of identical covers woodcock have been flushed year after year, when not a single bird could be found in equally suggestive contiguous shelters. It is the easiest bird to shoot in the world when forced into the open, but given the nmbrage of a friendly copse and the long bill twists its way in comparative safety. In Clina woodcock run from $\mathrm{I} 2$ to 14 onnces in weight, the females generally weighing the heavier. Small as has been the sportsman's luck of late years, the Shanghai market continues to be fairly well supplied, and surprising is the size of the "catch," whether by net or gun, often made on the northern shore of the Hangchow Bay from the Yangtze Cape to the Tsientang river when a flight has been greeted by the keen native market shooter. Fifty to one hundred birds is no 
uncommion result of a couple of days' and nights' work. Unfortunately when woodcock are bagoged in great numbers it generally occurs in warm weather, with the consequence that the birds are cast indisscriminately into the filthy native ice cnest to keep them fresh, but where they soon becone unfit for the table.

The Quail (Coturnix communis) was once fairly common throughout the breadth of north China, and for some years really prolific on the islancis in the reaches of the river near Hankow. But though always a favourite on the table it seens to have been a bird that never had any attraction for the sportsman, who of ten must think in these days of its scarcity and of his many lost opportunities. These birds are usually found singly or in very small companies of three or four, never in the large coveys of old. They are essentially running birds and only take to flight when suddenly surprised, when they offer, as a rule, comparatively easy shots, as their flight is both level and straight. Quail are seldom found in damp ground, but may be looked for wherever short buffalo grass abounds, in the long 
stubbles left by the Chinese sickles, and on the marsh lands in the dry season. On open grounds like these they readily fall victims to the deadly drag-net. The captives are then secured in low flat baskets, topped by a cloth, and forwarded alive to the varions markets. Considerable numbers are also sent sonth to Canton and other cities in the south, where they are largely bought for sporting purposes. The quail is a very pugnacious little bird, and would seem to like figliting for fighting's sake. After a battle or two they become real experts, and good fighting birds can always command long prices at the hands of the lovers of the main. Quail possess a very strong scent, as evidenced by the great distance at which a dog may at first point them, and lie well. A light charge of No. 8 or No. 9 shot will be found to be ail that is necessary.

It is on record that quail in China once "were often so numerous as to obscure the sun in their flights," but that time may certainly be put down as prelistoric.

The Wild Turkey, sometimes called the Turkey Bustard (Otisdybowski) is also scientifically known as otis tarda from the 
sluggishness of its flight.

It is a large bird of a very dark greenish bluish colour, almost black, and often attains a weight of ro 1 bs. Throughout the winter it is common enough in the Yellow river and Yangtze valleys as attested by its abundance in the markets. Formerly it was rather despised as a table bird, but of late years it has become, if not fashionable, at least more appreciated. Its flesh is dark, but very palatable when the bird has been hung for some time.

It is now some years since the foreign sportsulan has accounted for any success when after them, while the best record dates from I 880, when five birds averaging abont 9 lbs weight fell to double shots from a brace of guns.

The above list by no means exhausts the category of birds that fall to the gun in Clina. To enumerate but a few more, there are the sandpipers, the stints, the curlews, godwits and whimbrels, all belonging to the great family of Scolopacidae: the grey and golden plovers and the lapwings of the family of the charadridae, and the pigeons, the big bluish description 
(Turtur rupicula) which frequents the pine woods on the liill sides, and the modest dove without which no native village is complete are the herons, the egrets and the bitterns. And this catalogue fails to complete the tale of feathered beauties indiscriminately, inexcusably and inanely fired at.

China is singularly poor in the variety of its ground game. Apart from the larger ferals which, with the exception of the tigers in the Amoy district, seldom if ever fall to the gun of the average sportsman. China game resolves itself literally and simply into the two classes of deer and hares.

Of the antlered deer there are but two kinds, and so rarely are they met with, living as they do so high up amongst the thickly wooded nountain fastnesses, and consequently far beyond the range of any places accessible by houseboat, that it would be a real red-letter day for that sportsman who had the luck to account for even a pair of liorns.

The large deer of the Yangtze Valley, named after a popular commissioner of customs (Cervus Kopschi), is said to be 
fairly abundant on tlose hill ranges in Anwhei and Kiangsi to the south of the Poyang lake. It frequents, according to Mr. Styan, the hills, steep and covered with the densest brushwood through which it is very difficult to force a way without creating a disturbing noise, and in which, as all who enter Chinese hillside covers know, it is well nigh impossible to obtain a reliable shot. It would seen" "to spend most of the day hidden in the long grass at the bottom of gullies where it can neither be seen from afar nor approached quietly. A chance shot might be obtained in the evening when the deer come out to feed, but the usual method employed by natives is to organize a big drive. They line all the passes along the head of the valley with guns, perhaps a dozen or twenty gingals," and the beaters work upwards, shonting and tapping the trees, and driving as well as they can the game to the hill crests. The Chinese sportsmen know as well as their foreign confreres that all ground game is adept in the art of doubling back, and consequently make such contingent provision as they can to thwart the wily object. At the same time they know that the deer have their 
runs just as surely as have pigs and hares, and, knowing exactly where those runs are, post themselves accordingly. There would seem to be little doubt but that the thoroughly organized beat by a party of unjealous, fatigue-enduring foreign sportsmen, who followed implicitly the instructions of the indispensable shikari, would meet with some of the success it deserves. But it would have to be undertaken by a new generation of sportsmen unspoiled by the sybaritic luxuries which the present day gunner appears to regard as absolute necessities.

The Kopsch deer is a fairly large animal as may be inferred from measurements of a specimen in the Shanghai Museum :-There are at least four varieties of muntjacs, or small antlered deer, but the number shot in a decade might easily be connted on one's fingers.

There is the crying muntjac (Cervulus lacrymans ) by no means rare on the steep well wooded Chekiang hillsides. It is a diminutive animal weighing a little more than the average hare, and rarely condescends to the plains. Still at Kashing, only 
seventy miles to the west from Shanghai, two specinens were shot in I894. The few who have ever come across them at the table pronounce thein a delicacy second to none.

The common inuntjac of India (Cervulus Muntjac) is a very near relation, and is often known as the ribbed-faced deer. The muntjacs are peculiar in having short horns five or six inches long growing ont of bony pedicules which protrude several inches from the top of the skull in line with the face. The coat is very glossy and the colour of our species (The Yangtze Valley species, Styan) is rich chestnut above, very red on the tail, and belly white: two black lines on the face, whence the Indian name. It lives among thick covers and bamboo copses on the lills and may be found at an elevation of two or three thousand feet.

According to Mr. Styan, in "With Boat and Gun in the Yangtze Valley," three other kinds of muntjacs are found in the Chekiang hills.

Reeves' muntjac (Cervulus Reevesi) a smaller and paler species. The hairy-fronted muntjac (Cervulus crinifrens) rather 
larger with a deep brown body, yellow brown head, and a large tuft on the crown, (whence its name) which conceals two very short horns.

Michie's Muntjac (Elaphodus Michianus) of a deep gronnd colour all over, except white belly, white tips to the ears and pale lines over the eyes. This species also has a large tuft concealing very small horns.

But the deer too well known to sportsinen, generally and most ignorantly spoken of as the hog deer, a name applicable only to the Indian species with small antlers, is the hornless river deer (Hydropotes Inermis). This animal possesses none of the characteristics of the ubiquitous deer except the gift of speed. The senses of liearing, sight and sulell are by 110 means accutely developed, or the gunner would never obtain the number of close easy sliots he gets at these animals. Again they differ from deer generally in as much as they are prolifically parturient, often giving birth to five young at a time, while the foetus of an ordinary sized doe has been found to contain as many as seven embryos; wlile another marked point of difference is the coarse, almost 
bristly, nature of the hide.

For nearly twenty years after the Taiping rebellion the low lying lands in the province, especially known as the Kashing Plain, and the endless reed beds to be met with to the west of the Tai Hu, were the favored haunts of the river deer, but now an energetic cultivation and an acutely active reclamation of the marsh lands have driven them to the countless asylums which the river Yangtze affords, and whence the market supplies are derived. When the river is in autumn flood, and the bordering lands inundated, the loss of deer life must be appalling, for thongl the deer is both a quick and a strong sivimmer, it stands but a poor chance when it attempts to stem the resistless current, as those best know who from the deck of a river steamer have witnessed the loss from drowning. As had already been said, there is no skill required in and no sport derived from killing the local deer, which are always at the mercy of a charge of No. 8 shot. But the natives have a double view in its slaughter: the first is protective, for there can be no shadow of doubt that deer play havoc with the grain 
crops : the second, economical, for the deer is always marketable, though it is difficult to see where the "chance" is when deer are freely sold in the Shanghai market at from $\$ I .50$ to $\$ 2.50$ a piece, which covers the by no means insignificant profit of the native market man.

A characteristic but rather cold blooded way in which the native circumvents deer may sonetimes be seen on the Yangtze River. The northern end of the Poyang lake which debonches on to the river at Hukow is fringed with long flat reed beds, intersected by short cuttings which practically make them small islands. Herein after their nocturnal feed on the mainland the deer seek quiet and safety during the day. With this knowledge the natives, having cut off retreat from their quest, proceed to beat the covers, which are easily reached in their shallow boats. Driven to extremes the deer take to the water, where as often they are stunned by the heary bamboo as they are killed with the native favorite load of mixed iron shot. And, doubtless, similar systems obtain in other parts of the country. 
In this connection it may be interesting to note a fact not too generally knowin. The Chinaman shoots with iron shot which do not acquire that perfect rotindity to which the users of tower-dropped lead shot are so well accustomed, and, as the sieve is not used, only approximate uniformity of size by hurried hand picking is obtained. Sometimes this simple precantion is not taken, and the charge may be found to be a heterogeneous mass of spheroidal pellets, ranging in sizes from number 9 to buckshot. The native certainly is a believer in mixed shot.

On excellent authority it may be stated that over 2,500 deer are sold during the season in the Shanghai markets, and that seldom is the price of $\$ 2.00$ per head exceeded. Such venison as is afforded by the river deer is by no means considered a table lixury, but the flesh, nevertheless, constitutes in conjunction with good beef steak a valuable base for a game pie. And, anomolus as it may sound, what might pass as excellent jugged hare and hare soup may be derived from the proper culinary treatment of the river deer. 
The river Yangtze is the dividing line between the ranges of the two species of hares which are met with in China. On the north bank and hinterland is found the larger species which very closely resembles its European congener in its habits, size and coloring. It has its "runs" as surely as ever has the English hare. A fair average weight may be placed somewhere between five and seven pounds, and the animal has the distinctive black points and tips to the ears, while the upper surface of the scut is black. For long this hare was confounded with the Mongolian species (Lepus tolai), but it is now anthoritatively stated to be a distinct species, and has been named after a late naturalist consul to China, Lepus Swinhoei. Known also as the Shantung hare, it is slipped in large quantities to the Shanghai market, whose other great source of supply is Nanking, from which place a consignnent of fifty brace is by no means uncommon.

The other species, the one whose habitat is to the south of the river, used to be fairly plentiful throughout this and the adjacent provinces. Comparatively, it is an 
insignificant, small reddish-brown animal with a rufous patch at the base of the neck, the ears and upper part of the tail much the same colour as the back. It is generally known as the Chinese hare (Lepus sinensis), and weighs from two to three pounds.

Like the deer, the hare in China is a prolific breeder often giving birth to a litter of four or five leverets.

Wild fowl :

" Wedge their way

Intelligent of seasons, and set forth

Their aery caravan high over seas

Flying, and over lands, with mutual wing

Easing their flight."

Wild fowl begin to put in appearance in North China generally towards the end of September, that is those of the duck tribe, for the arrival of the swans and geese is always much later, and would seem to be entirely dependent upon the clinatic conditions in the Far North.

In common with all the other varieties of birds which participate in the Great Asian migration scheme, the wild fowl that visit China breed in the early summer months in that dreary, swampy, treeless, 
mossgrown waste known as the Tundra, which stretches from the Gulf of Obi on the west to Behring's straits on the east, its northern limit being bounded by the Arctic Ocean. During the open Arctic season, in the countless tributaries of the great rivers and in the innumerable lagoons which characterize that region, wildfowl find the food in which they delight, and it is only when those food supplies are cut off as they are when the gromnd become hidden in frozen snow and the waterways covered with ice, that the instinct of self preservation, chief amongst known causes, impels migration to a kinder climate with its nore easily obtainable food.

The passage of most migrants is steady from north to south, that is continually progressive towards the limit of the migration. Not so is the case of wild fowl in North China, for birds will be found to be in numbers at a certain place at a certain distance south one day only to be discovered at a certain distance north on another, a fairly conclusive proof that their movements are largely influenced by the temperature. Cold weather will drive the birds in a southerly direction, a warm break will 
incline then again to the northward. The inland waters testify to this, for one day they may be literally black with fowl, and the next as bare as the proverbial billiard table.

The line flight of wild fowl is nothing like so extended as in the cases of many other migrants. It is placed by Mr. Dixo11, in his "Migration of Birds," in the "moderate range," that is, a range of 3,000 to 5,000 miles. But the Corncrake and the Cuckoo fly from 6,000 to 7,000 miles, whilst antong the birds of the most extended flight are the whimbrel, the curlew and the well-known Asiatic Golden Plover which traverse between 6,000 and ro,000 miles. The mileage is, of course, approximate, and represents a course almost due north and south; but few, if any species, travel so direct, so that the actual distances traversed may be in excess of the actual figures given. A point of interest is suggested by Mr. Dixon and that is, the daily distance accomplished, for it must be evident that the migrants must settle sonewhere in the twenty-four hours for food and water and rest. "Probably," says this authority, "migrating birds do not average more than 300 miles 
per day; but certainly birds travel quicker northward in the spring than they do southward in autumn."

As far as China is concerned, the wild fowl after quitting their breeding grounds in the region of the Arctic Circle, pass over Siberia and Mongolia, and settle for the winter months between the parallels of 40 and 20 north latitude. Shangliai should be eminently well situated for the observation of the migratory flightings, situated as it is between the wide estuaries of the Yangtze and 'Tsien Tang rivers, but very rarely are the birds seen as they pass over, though distinctly heard and apparently tantalizingly near.

“. . . . . . Wild birds that change

Their season in the night, and wail their way From cloud to cloud. . . . . . . . '

Wild fowl naturally put in their first seasonal appearance near Tientsin two or three weeks earlier than in the more sonthern provinces. Hence their course is slowly southwards, and as far as the sportsman is concerned it terminates at Swatow. But the flight line is a broad one, embracing the area whose western limit may be defined by the one hundredth meridian of east 
longtitude, and the eastern by the coast line of China.

Before making mention of those inland waters and waterways where the sportsnian under ordinary conditions might be expected to come upon his quest, it may be useful to acquaint him with the several varieties of fowl he may possibly come across.

In the first place there are two kinds of swans. The Whooper or Wild Swan, somewhat scarce, and Bewick's Swan, which is very common.

Then there are six descriptions of Geese; the Grey-leg Goose and the White fronted Goose, neither very common; the Bean Goose, the lesser White fronted Goose, the Swan Goose. The former very common and the latter not infrequently met with; and finally the Pacific Brent Goose which is better known in Japan but may be niet with annong the many islands on the China coast.

Of Duck, the better known are the Mallard, Pintail, Sheldrake, Shoveller, Pochard, Scaup, Golden eye, Velvet Scoter, Widgeon and the Gadwall, while the Teal include the Common Teal, the Spectacled 
Teal, the Falcate Teal and the most beautiful of all, found only in China, the Mardarin Duck.

There is also the Siberian Winite-eyed duck, spasmodic in its appearance, but when met with seems to be numerous. Other birds uselessly shot are Cormorants, Coots, Goosanders, Sinews and Moorhen.

The Whooper or Wild Swan (Cygnus ferns) is the largest of the genus and may easily be recognised, not only by its unusual size, but by the shape and colour of the beak which is slender in form, black at the tip and yellow at the base. It is a comparatively rare bird in China but may occasionally be seen in the hardest weather in numbers of from ten to fifteen. Ordinary weights are from eighteen to twenty-two pounds, while measurements from tip to tip of extended wings run from seven to eight feet.

Bewick's Swan (Cyguus minor) is very conn1110n all along the coast. At certain times these birds may be seen in hundreds as they stand marshalled like soldiers on the ooze round the islands of the Yangtze Estuary. Its distinguishing mark is a large patch of orange at the base of the 
beak. It is only about half the weight of the Whooper, averaging about ten pounds. The stretch of wing is from six feet to six feet six inches.

For sake of discrimination, Geese may be divided into two groups :

(a) Those having the "nail" at the tip of the beak white or of a very pale flesh colour.

(b) Those in which the "nail" is black (Newton).

The Grey-leg Goose (Anser cinereus) is the largest of the Grey Geese, and weighs from eight to ten pounds. The bill, legs and feet are pale pink, the body buff with brown bars.

The White-fronted Goose (Anser albifrons) not common in China. Legs orange, bill flesh colour, nail white. Breast plumage shaded white with transverse bars of brownish grey and black. Its distinctive white-band on the foreliead accounts for its title Alba frons, white-fronted.

The lesser White-fronted Goose (Anser erythropus). This is really the common goose of China, and may readily be distinguished by its bright orange bill and legs and its mouse-coloured upper wing 
coverts, to say nothing of its very conspicious white face and the broad black bars which cross the belly. (Newton). It is what may be called an inland goose for it is found throughout the breadth of China. Towards evening it makes for the open waters where it congregates in enormous gaggles as may be witnessed by any who pay a visit to the margins of the Hangchow Bay, the Great South Lake, or any similar broad waters.

In the early morning it seeks its food on the stubble, on the ploughed land, amongst the younger winter wheat and in the bean fields. It is a greedy feeder, and so intent is it on this question of food that it often may be very closely approached. The usual plan adopted is for the gunner to walk as unconcernedly towards the flock as possible, and when it begins to show uneasiness to run in twenty or thirty yards, select his bird and fire. To shoot into the "brown" of geese is about as useless as firing into teal on the water. Weight from eight to ten pounds.

The Bean Goose (Anser segetum) is to be found in great numbers in the estuary of the Yangtze and the upper reaclies of the river, and wherever there may be broad 
running fresh water. It is easily identified by its long bill, which is black at the base and tip and orange in the middle, and its orange legs. Weight seven and a fonrth to eight and a half pounds.

The Swan Goose (Anser cygnoides) is a very large bird, and would seem to be the stock whence the domestic geese of several different countries have sprung. The ganders of the reclaimed form are distinguished by the knob at the base of the bill, but the evidence of many observers is that this is not found in the wild race. (Newton). The bill is black, and a conspicious dark stripe runs down the neck. Moreover its neck is very swanlike.

The Pacific Brent Goose (Anser nigricans) is distinguished by having the bill, head, neck, breast, feet and tail a sooty black; on each side of the neck there is a patch of white with a few black feathers intermixed. It is the smallest of all geese, and is practically the "blackbird" of the anseres. Doubtless it is to be found round the Islands of the China coast, for it is a seabird entirely, never flying inland.

Unlike ducks, geese are of almost identical colour in both sexes, and according to Sir 
R. Payne Gallwey "there is no perceptible difference in plumage between the male and female of any wild goose." In the case of duck and teal the fenuales are invariably of so sombre a colour that in n11any cases and at certain seasons it may not be so easy to determine at once the species.

Though admittedly inadequate the following description of the duck and teal in China, based upon examination of typical male specimens in the Shanghai musenm will, it is hoped, suffice to impress upon the mind of the uninitiated some of those more salient features and characteristics by which, witl comparative ease and certainty, a species may be determined. And that is all. For who shall attempt with any realism to depict, "Artist in words" though he be, the gorgeous sheen of the cock plieasant's breast, or the iridescence of the beautiful Mandarin duck?

There can be no question that an ability to discrininate between the several species which may be found in the day's bag would greatly enliance the interest in the sport, but unfortunately, in the case of too many shooters, the contents of the bag are birds 
and birds simply, and like the Wordsworthian flower " nothing more."

"A primrose by a river's brim

A yellow primrose was to him, And it was nothing more."

Or as Sir R. Payne Gallwey puts it tersely and emphatically :- "To most shooters a duck is a duck, and a wild goose a wild goose, but the successful fowler will tell you of a dozen species of the former, and half as many of the latter."

The advantages, therefore, of even a very modest acquaintance with natural history must be obvious in so far as birds and their ways and their more marked features are concerned. Such a knowledge, though linited perhaps, could not fail to lead to a closer observation of "winged beauties" generally, naturally to a more intelligent interest in sport, and consequently to enjoyments unrevealed to those whose cup of happiness is only full in proportion to the weight of the bag.

And here it may not be ont of place to offer a suggestion. Let him who has never done so before take a bird from the bag and make but a rude sketch of it ; then let him try lis hand at a description of the plumage, 
and he sliall discover countless combinations and permutations of the seven primary colours, and such a variety of tints as were never dreamt of in his philosophy. The task, which after all should prove to be a pleasure, would make such an indelible impression upon the memory that he would never be in doubt again as to the species of the bird in question, and might possibly be grateful for the lint here throwil out.

For all practical purposes duck and teal may be divided into two well defined and clearly distinct classes, "the surface feeding species, or those that never dive to obtain food, further than they can reach without entirely subnerging their bodies, or the diving ducks, or those that do dive to procure food from the botton of the water." (Badminton.)

Of the eighteen varieties hereafter named but five belong to the diving species.

The Mallard (Anas boschas) from its frequency and popularity may well head the list of the surface feeding ducks. Head and neck rich glossy green, perfect collar round the neck, and short crisp curly tail feathers. Weight 2 lbs to $2 \mathrm{r} / 2 \mathrm{lbs}$. There is also another linck, locally known as the black or 
yellow-nib duck (Anas zonorycha) a larger bird with black bill and orange band across it. Weight from $2 \mathrm{r} / 2$ to 3 lbs.

The Ruddy Sheldrake (Cascara rutila) is one of the handsomest of ducks, "vividly marked in contrasts of chestnut, black and white." Head and neck glossy green, white breast and belly, yellow bill, broad rich rufous brown band from the lower end of the back of the neck which crosses the breast, tail wlite with black tips. Weight 3 lbs and more.

The Widgeon (Mareca penelope) may be recognised by its light fawn crest, rich rufous neck, light reddish grey breast, grey mottled back, white-barred wings, and long tail. Weight from $\mathrm{I} / 4$ to $\mathrm{I} / 2 \mathrm{lbs}$.

The Pintail (Dafila acuta) one of the largest of the duck family, sometimes called the sea pheasant by reason of the great length of the two central tail feathers of the male. Its head and neck are a rich dark brown, and its back pencilled with black on a grey ground. Throat, breast and belly snowy white. Weight $3 \mathrm{lbs}$ and $\mathrm{up}$.

The Shoveller Duck (Spatula streperus) is uncommonly like the ordinary greyducks in appearance, and at Kiukiang it has more 
than once been shot by mistake. "The breast feathers are covered with tiny crescent shaped pencillings which are a sure means by which to recognize the species. Ordinary weight 2 lbs.

The Common Teal (Querquedula crecca) most delicious of table birds, is found in great numbers throughout China. Its distinguishing marks are rich, chestnut brown head, upper half of face dark, glossy green; lower half rich chestunt. Above and below the eye run two narrow streaks of buff sharply dividing the green and chestnuts. Breast tinged with purple and covered with circular black spots. Weight I4 oz. to I $1 \mathrm{~b}$.

The Garganey Teal (Querquedula circia) is not a common bird in China, but still it may now and again be met with. It is a striking looking duck with its glossy green black crest, black bill, white band from eye to back of neck, breast mottled brown and black : long fine wavy black feathers centred with white. Weight I lb to I $1 / 4$ lbs.

The Spectacled Teal (Eunetta formosa) very common on the Yangtze, is not improperly named from its markings in the region of the eye to chin. Its chin and 



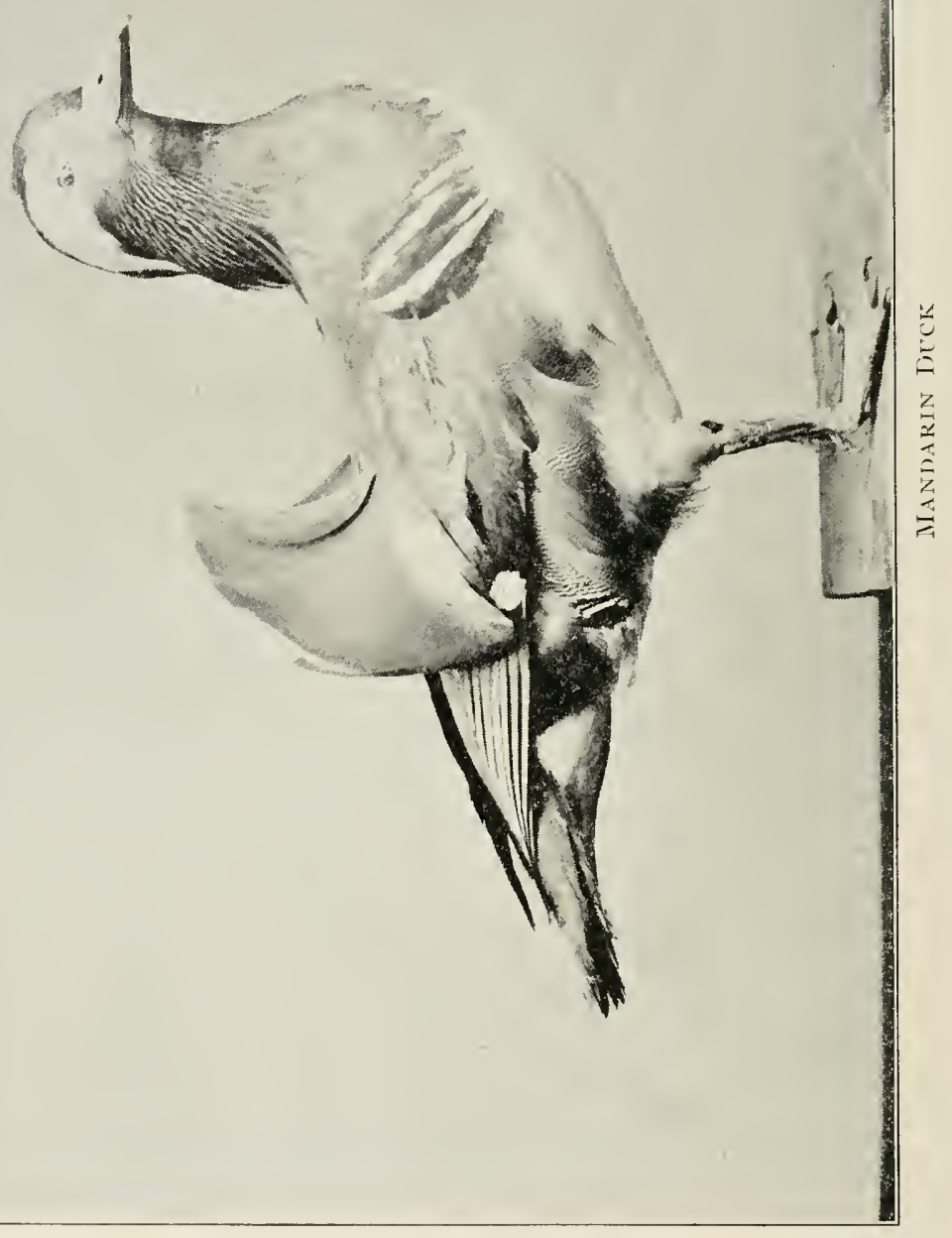


crest are a dark green. The body, generally, is of a pale buff colour. Weight about I $1 \mathrm{~b}$.

The Falcate Teal (Eunetta falcata) is another very common bird in China. It is a very graceful looking fowl, with its long drooping grey back feathers. Head rufous brown, bill black, clin white, breast and belly beautifully mottled grey. Weight I lb.

The Siberian White eyed duck (Fuligula baeri) is described by Styan as "scarce in its appearance, but when met with it seems numerous."

The Mandarin Duck (Aix galericulata) is the most gorgeously plumaged of any of the ducks. Once it was fairly common in both provinces of Kiangsu and Chekiang, but its numbers have been sadly thinned of late years, largely for the feathers which are chiefly exported to Paris.

Wood, in his natural history, offers this word picture of this lovely bird: "The crest of this beautiful bird is varied green and purple upon the top of the head, the long crest-like feathers being chestuut and green. From the eye to the beak is a warm faw11, and a stripe from the eye to the back of the neck is a soft cream. The sides of the neck are clothed with long 
pointed feathers of bright russet, and the front of the neck and the breast are rich shining purple. "The curious wing-fans that stand erect like the wings of a butterfly are chestnut edged with the deepest green, and the shoulders are banded with four stripes, two black and two white. The undersurface is white.

This completes the list of surface feeding ducks, all of which are most excelleut table birds, each with its distinctive flavor, and all with their respective champions. Truly China is most fortunate in the abundance of its wildfowl supplies.

The Diving Ducks in Clina are limited in variety and not at all prominent in numbers. The species most frequently met with is the Pochard (Fuligula ferina) which may be recognized by the chestnut red of the head and upper part of the neck, and the rich, deep velvet black of the lower part. Its grey blacis is profusely sprinkled with flecks of a darker tint. Its bill, and this feature is very important, is black at the point and base, and pale blue in the middle. In Europe, it is variously called "the Poker, Dumbird or simply' Redhead." Its weight runs from I $3 / 4$ to $2 \mathrm{lbs}$. 
The Scaup (Fuligula marila) is a very short, thickset bird. Its head is black as is also its bill; breast grey mottled, wing coverts black with white bars; undersurface greyish white. Weight $\mathrm{I} / 2$ to $2 \mathrm{lbs}$.

The Tufted Duck (Fuligula cristata) so named from the feathers on the back of the head which form a drooping crest. Head, breast, neck and all the upper plumage, black with green, bronze and purple tints; under plumage winite. It is said that with the exception of the Pochard it is the only diving duck that is fit for food, but those who once have had an experience of the "Fishy" flavor of any of the divers have never been known to desire a repetition of tlie dish.

The Golden-Eye (Clangula glaucion) is one of the handsomest ducks that swinl. Its head is very dark brown or black, beautifully shaded with violet and green. The body generally is grey, the undersurface grey terminating in white. The wings are white barred.

The Velvet Scoter (Aedemia fusca) as pictured in Badminton is of a rich, velvety black plunnage; a white crescent-shaped post under each eye, also a white patch on 
each wing. The bill is orange, edged with black, and the lump at the base of the bill is also black. Weight 2 to $2 \mathrm{r} / 2 \mathrm{lbs}$.

It is hoped that the foregoing presentation of the chief distinguishing features of the various species of wildfowl most commonly met with in China may be successful in accomplishing even a small part of its contemplated object, which mainly is to foster a more enquiring and intelligent observation on the part of the shooter, and to provoke a keener interest in the beauty, the mysteries and the study of bird life.

'There is an old saying to the effect that you must first catch your hare before you cook it. Bear then with an attempt to "catch our hare" or, in other words, to indicate where and when and how one is most likely to come upon his quest and how we may best secure it.

Wildfowling in its sense has never what is vulgarly termed "caught on" in China, possibly for reasons among which may be included the time necessary for its successful prosecution, the expenses attendant upon it, its many disappointnients, dread of the tricky nature of the currents of the Yangtze estuary; but, perhaps 
beyond all these the absence of the enthusiasm without which the fowler is nothing worth. Fowling demands pluck, endurance, patience and the keenest relish for the sport at all times, in all conditions of wind and weather, and that classical aequa mens in rebus arduis, which is indispensable.

As far as is known few attempts, other than in the Yangtze estuary, liave been made to systematically circumvent wildfowl, and what I write must be limited accordingly to that locality. Just ontside Shanghai is a line of islands stretcling towards the sea, Tsung-Ming, the largest of them all and nearest, then in succession Bush Island, Small Island, Block House Island and House Island; in fact twenty miles of low land, shoals, swamps and reeds. These islands are intersected by innumerable small tidal creeks. Opposite to these, on the right bank of the river, are the well known Beacon Flats, a long expanse of mud at low water. On these shoals and in the contiguous swampy reed beds fowl of every description delight to congregate.

When the birds arrive in quantity, a fact intimated by the "flying squadrons" outside 
Woosung, it behoves the shooter to look after both boat and gun. Respecting the former the exact thing is be found at Woosung in the native river sampan, a shallow, keelless flat-bottomed boat about 30 feet long, 8 broad, with a depth of about 4 feet. The craft is strengthened by transverse bulklieads which form four absolutely watertight compartments. A lug sail set on a 30 feet mast will carry it gaily through the water under favourable conditions. When the wind falls recourse must be had to the yulol, a powerful scull which can make a large boat travel much faster than might be imagined. One's armoury is, of conrse, merely a matter of choice. Mr. Duncan Glass, in an invaluable contribution to "With Boat and Gun in the Yangtze Valley," advises the use of a 4 bore, if not too heavy for the shooter, otherwise a double-barrelled 8 bore, full clioked and an ordinary $\mathrm{I} 2$ bore as a cripple stopper. As to shot, No. 2 will be large enough for tlie 8 bore, No. 4 for the fowling piece. Once started, your field glasses will soon enlighten you as to the whereabouts of your quest, when your boat sliould be put into such a course as will enable you to 
sail right down upon the gaggle or whatever it may be. It might be even imperative to drift upon the birds, but under no circuinstances should tliey be approached by tacking or any similar zig-zag course. As fowl require the wind against them as a fulcrum to raise them from the water, so it naturally follows that when you are able to sail "upon" the birds they will have to pass your boat, either to the right or to the left.

Nothing is here said of punts or swivelguns, for the Yangtze is too often too rough to allow of the use of the one, while the discharge of a pound of lead into the brown of a company of birds, when the few only are killed and the many wonncied, is a barbarity which happily may not be expected to be tolerated much longer.

But it may be that the shooter desires a shore experience. The boat will then land him at the month at one of the many little intersecting creeks, in which the islands abound, up which he may go, if so disposed, in the inevitable attendant of these larger boats, a small dingy, or at once make his way through grass, and swamp and feeds until he "happen" upon the unsuspecting 
fowl when he will find that his 12 bore will answer every purpose.

At Hankow, 600 miles up the Yangtze, geese may be seen in thousands upon the great plain there. Time was when the gunner used to ride up to the birds as near as they would allow him. But neither that mode of obtaining a shot nor by firing at them with a rifle ever went much beyond the experimental stage. At Ningpo, upou the lakes, fairly successful bags have been made by punting a dug-out or shallow craft throngh the reeds; but the difficulty of recovering the cripples is a drawback, for ducks and teal when dropped have a happy knack of hiding annong the tussocks, or diving into the floating grass or weeds to whose roots they cling with a tenacity only terminated by death from drowning. But luck in fowl shooting comes as often to him who "happens" upon birds as to him who systematically pursues them. When birds are first sighted in a creek or circumscribed waterway it would be well to take bearings by some landmark of their exact position, and then under cover of such shelter as there may be advance unhesitatingly. However, in any case, the endeavour should be 
made to get the wind as much behind the shooter's back as possible in order to ensure a closer shot than were this precaution not taken. This is a simple but a golden rule, applicable alike to plover, snipes and wildfowl, and its neglect is the frequent cause of a disappointment which otherwise had beell avoided.

Capital fliglit sliooting may sometimes be obtained as the birds top the neighbouring low hills on their way to and from the lakes at Ningpo ; but exciting and entrancing as the sport is, it is but a short time pleasure, never lasting more than an hour, and but too often only a fractional part of that time.

All the arts of Chinese fowling which are many, curious, and often eminently practical, are exercised by the native punters, from whom the foreigner has much to learn, upon the broad waters of the Tai $\mathrm{Hu}$, the Great Sonth, the Poyang and the Tungting lakes. The river steamers bring to the Shanghai market ample practical proofs of the successes of the China "Shooty-man."

At Wuhu, in Anwliei, 400 miles up the Yangtze, the country for miles is protected from inundation by huge dykes of great length crossing each other at right angles, 
which give to that part of the country a cliess-board-like appearance, the sides of the quadilateral being high banks, and the areas grass and grain and reed fields in which geese find abindant food. Sending, to the rear of a large flock of geese feeding, their third gun to startle them, the other two guns of a shooting party concealed by the embankinents had a fine time with the driven birds, securing no less than1 32 head. This was in December I9or, when in eleven days on the Taiping marsh this same party accounted for 270 head of wildfowl, viz: I 76 geese, $5^{8}$ duck, $5^{6}$ teal.

With decoys judiciously placed, and shooting from behind ordinary reed blinds, an American sportsman, in February I896, on Block House Island, in the Yangtze estuary, in ten tides bagged 362 dinck, 42 geese, and 18 swan. "Tlie swan gave close sliots; 3 fell to as many No. 8 cartridges." Since I900, the best anthenticated mixed bags are:

At Kashing, 70 miles W. of Shanghai, for one gun in 9 days, 96 pheasants, I I woodcock, 5 hare and 9 partridges.

At Wuhn, 2 guns, 2 I I/2 days sliooting, I 3 I6 head, made up of 889 pheasants, 27 
deer, 254 teal, 24 duck, 26 woodcock, 32 hares, I 8 partridges, 9 geese, 32 snipes, I bittern, 2 foxes, I wild cat, I ground hog.

Hangchow district, 3 guns, 3 days shooting, I 50 head, made up of 39 pheasants, 27 partridges, 50 woodcock, 9 hare, I goose, Io teal, 4 snipes, ro quail.

On the Tsien-Tang river, near Hangchow, in I9O3, 5 guns, I4 days shooting, and 3 guns, 7 days' slooting, 640 head of a very mixed nature, 334 pheasants, I 5 partridges, 89 quail, 29 snipes, I 5 woodcocks, I I hares, 2 deer, I goose, 3 duck, 8 teal, 26 pigeon, I plover, 2 foxes, I corncrake, I civet cat, I wild cat, I coon dog.

These facts and figures are merely adduced as evidence of the delightfully various nature of the shooting still to be obtained in China, though, unfortunately, in rapidly dininishing quantity.

A few of the reflections that may not unreasonably arise in the minds of those who have been sufficiently interested, in what has been written on the small game of China to have given them some little consideration, nay now be briefly st1m111arized. 
The most important, but all too selfevident fact is that the game supply, as far as foreigners in China are concerned, is visibly and rapidly diminishing. How, then, may something like a status quo ante be reestablished? There is still plenty of game in Clina, certainly in the northern part, or there would not be such bountiful supplies for sale at such moderate prices as are asked in the market. To say that "China is shot out" is not to generalize but to localize. In a sense it is getting shot out, but almost entirely in those districts which foreigners lave made their dwelling centres, and where abound hosts of indiscriminating, irresponsible, thoughtless shooters of all nationalities. The question naturally arises how best to check this irrational gunning, and then low to resuscitate the local gane supply? Moral suasion and the imposition of a shooting license 1night help towards the solution of the first question. Some sclien1e might be formulated including the importation of game birds from the interior or from abroad, the importation of eggs from foreign conntries, which might easily be done with safety in these days when a temperature 
of any required average heat in the splendidly equipped steamers of to-day might be relied on. And in this connection it may be here mentioned that eggs purchased in Yokohama have been hatched out in Glasgow, which eggs must have been at least ten weeks old if the passage time be allowed for and the three weeks imperative for incubation. The scheme might further provide for the safeguarding of both eggs and game when located. To some such schene n110st of those who carry a gun miglit reasonably be expected to subscribe. The free-lances would possibly not be so 1111merons as 111ight be supposed. There is nothing after all very empirical in the suggestions.

Again stricter attention might be paid to the observance of the "close" season. It is shameful and pitiable that pheasants should yet be found on certain tables in July and August, but it is a fact, nevertheless. One thing is certain and that is that some active steps will have to be taken in the very near future, if there is to be any game shooting within the radins of the larger treaty ports, of which Shanghai is chief. 
On the other hand Shanghai, to say nothing of some other places, enjoys a full supply of varied yet very cheap ganie. On the authority of the most infuential and largest game dealer in the place, whose figures if they err at all err on the conservative side, there were sold in the local markets and shops in Igo5 the following quantities of gane at the prices placed against then1 :-

30,000 plieasants at from 60 cents to $\$ I .50$ per brace.

35,000 suipes at from 25 cents to 35 each. 20,000 wild duck at from 80 cents to $\$ 1.00$ per couple.

IO, OOO teal at from I 5 cents to 30 each. 2,000 wild geese at from 60 cents to 80 eacli.

3,000 woodcocks at from 70 cents to \$I.OO each.

3,000 hares at from 40 cents to 60 each. 500 wild turkeys at from $\$ 1.00$ to \$I. IO each.

40,000 quail at from I 6 cents to 20 each. 2,500 deer at from $\$ \mathrm{I} .50$ to $\$ 2.00$ each. 
And these figures are quite independent of the heavy requisitions of mail steamers, coast boats, and the various men-of-war that visit the port. The percentage of gan1e shot by foreigners, when brought into comparison with the figures given above, is insignificant in the extreme, and yet it is that very percentage which gained for China her fair name and reputation; and which the foreign sportsman legitimately and fondly desires to see rather increased than lessened. Whether the railway will eventually open up any virgin shooting grounds is at present a conjecture only. The railway, as so far opened, simply traverses districts only too well known to every sportsman. But it may be that some more light will be thrown upon this question now the line is in working order between Chingkiang and Nanking. That fair country to the west and north of Hangchow at present holds out the brightest promise of "fresh wood and pastures." Further west again, to the west and south of the Tungting lake, is that terra incognita of which Kweichow nay be termed the centre. 



\section{BIG GAME}





\section{CHAP'TER IV.}

BIG GAME.

If the shooter is fond of hunting big game he can enjoy the sport in China, but not in the sense it may be enjoyed in Africa or India. There are various kinds of wild animals in China and they mostly abound in the western section of the Empire. Their principal haunts are in the province of Kwei-cliow, and the neighbonring proviuces of Hunan, Kuang-si, Yunnan and Szechu'an. In Kuang-tung, Chekiang and Fukien the shooter, if he looks closely, will probably find a tiger or a bear, and if he goes to either of the three provinces of which Manchuria is composed he will doubtless see n1ore big ganne than elsewhere in the Clinese Empire. But it is likely that the greatest variety and the largest number of wild animals abound in Kwei. chow than in any of the eighteen provinces of China proper, the three Manchurian provinces not being included, for there the monntains are well wooded and the fertile valleys support the domestic animals on which they love to feed; and the towns and 
cities are not always exempt from the visits of a man eating tiger, a panther or a leopard.

Iion: The Chinese name for lion is Shih-tzu. This animal is seldom seen alive except in Kuang-si and Kwei-chow, and probably not at all now, althongh it is believed that a long time ago lions were numerous in Kuangtung, Kuang-si, Kweicliow and Hunan when these provinces were not so densely populated as at present. It is said that a Clinese General, Chao-T'o, as Prince of Yiieh, in the second century, B.C., was the founder of the famous old city of Canton and liad a pair of stone lions carved and set up at the principal entrance to his palace, the origin of a fashion which has been followed to this date, for since then it has been fashionable to erect a pair of stone lions near the principal entrance to all public offices and temples throughout the Empire. The stone lions are carved to sit on their haunches and placed so as to look inwards and with one paw resting on the globe as if it was intended to say, we symbolize universal dominion, might and power. In connection it nay be noted that Wei-t'o, the guardian angel of all Buddhist 
temples, is a vice-regal title of the ancient and illustrions Chao-t'o. Anotler fact is that from the $9^{\text {th }}$ to the I $5^{\text {th. }}$, both inclusive, of the first Moon, it is customary for young men of good families to go about town with a flexible innage of a lion, made of a bamboo frame work covered with orange colored silk or cotton cloth, and worked by three or more men, one of whom is dressed and sluaved like a Buddlist Priest and puts his bald pate into the lion's month. In western China this annual performance is called Shua Shih-tzu, perform with the lion, a fact which might indicate that performing lions were brought to China by Buddhist priests from some of the neighboring countries, Annam, Burmah, India or Siam.

During lis first campaign in Kweichow, I867-74, General Mesney learned that a large and ferocious animal called by the natives Ma-hswing, house bear, was occasionally met with by lion hunters, but as often given a wide nurgin, and allowed to roan1 about at its own will. This animal was described as larger than the largest size bear and with a mane like that of a horse, brown as an ox and ferocions as a panther; its roar could be heard miles away and all other 
wild animals fled for fear of it. The farmers were rather friendly disposed towards the Ma-liswing as it kept away the other wild beasts which devoured their crops and domestic animals, as its favorite food was the deer and the wild pig,-two of the greatest and most persistent deprecators known to the farmer. It would perliaps be a reasonable supposition that the Ma-hswing was a species of the African lion rather than of the Asiatic, as the latter is supposed to be m11aneless. It is certain that the lion captured in Siam and taken to Paris did not have any mane. And possibly the Mahswing is not of the African species at all, and different from the ordinary Asiatic lion, nay be a species new to science, just as there are several very different kinds of monkeys and pheasants in China, not litherto seen in other parts of the world. There is a large monkey in lower Kwei-chow called a Jen-hsuing, that is, a inan bear, and which may be abin to what the Welshman called a Glen-tober, whicl was declared to have "feet like hands and hands like a people."

Tiger: The tiger is known as the Ta11na, which is the native name for big-cat, 
and are more numerous in Fukien, Kuangtung, Kuangsi and Kwei-chow, especially in the last province. The proper Chinese word for tiger is $\mathrm{Hu}$ or Tao-hu. The climate of China has not abated the natural viciousness of this animal, whose depredations are not confined to the country, but one will daringly go into a town and destroy human life. The spoon of a large tiger has been seen under the walls of the city of Kwei-yang, which is the provincial capital of Kwei-chow, and was tracked over the snow into the monntains, some two miles from the city, where it had eaten its prey. The depredations are usually confined to carrying off of pigs, goats and dogs, but frequently the animal will attack an ordinary size ox and small ponies; one will seldom attack a water-buffalo, unless two or more are hunting together. If the water-buffalo has a calf one of the tigers will seem to attack the mother so as to give the other the better opportunity to carry off the offspring. These attacks, however, do not always prove successful, for a dead tiger has been found on the field of battle, as the result of the affection and courage of the mother. In the case 
of ponies and mules, which are generally from eleven to twelve liands high, a big tiger will attack, and often successfully. As many of the ponies are stallions, there is a fight at once when a stallion is attacked, and if but one tiger only the pony not infrequently comes off victorious. A single tiger will seldom attack a pony or mule in a caravan, because the leader is invariably a large stallion, a fact the tiger appears to comprehend and appreciate. Some of the tigers are fond of human flesh and do not hesitate, when there is a chance, to attack a man or woman. General Mesney was informed by a French priest, who resided near Cheng-an-chow, in upper Kwei-chow, that one day some of the people in lis parish came and reported to him that a maneating tiger had just killed a young boy and had carried the dead body to a neighboring hill, where it had eaten a part, and was still concealed among the rocks. The good missionary, though not a sportsman, acceded to the wishes of the parishsoners, and with gun in hand went hunting for the tiger. When he sallied forth in search of the guilty animal he was followed by many 
of his native friends, also armed and equipped, and upon arriving at the hill each was assigned his position to guard; soon the priest discovered the tiger crouching at the base of a rock on which he was standing and shot the beast dead. Fortunately, however, for the priest the tiger was killed, as the gun used was double barrelled and in the excitement of the moment, both barrels being discharged at the same time, the priest was fonnd on the other side of the rock almost insensible from its recoil. I hope my reader will not complain of the details I may give in connection witli the inclinations of some of the aninals whose haunts I wish to locate in a general way.

Leopards: The province of $\mathrm{K}$ wei-chow in western China is the province in which leopards are said to be nuore numerons. This animal is named Piao by the natives, but as it is sometines confounded with the naine for the panther, Pao, the leopard is also known as the Pao, or Pao-tzu. The largest leopards are about the size of a medium grown panther and are as ferocious and active as the latter animal. Of all the wild animals of China this one is a special 
terror to the flocks of the farmers, and a reward is sometimes offered by the officials for each leopard killed as an encouragement to native shooters. The native hunters eat the flesh of the leopard and aside from its nourishment believe that it makes them conrageous. A foreign friend informed me that he had the leg of a leopared roasted, and after larding and sticking it with garlic found it to be very palatable, but that he preferred beefsteak. If properly cured the skin can be made into useful saddle bags and very pretty rugs for the floor or for the bed. A nice rug of this skin can be purchased for about four United States dollars.

Bear: This animal is called Hsiung in Chinese, and like most of the big game is - found in greater numbers in western Clina and some parts of Manchuria; the nountain regions of npper $\mathrm{K}$ wei-chow is said to be the favorite haunts of bears. This region is the home of the Miaotzu and Lolo aboriginals and which, in Anglo-Saxon, may be described as Miaoland and Lololand, a region into which the Chinese have as yet been minable to successfully penetrate, and where these aboriginals live m1ler what 
may be termed home rule. If the shooter visits the mountains on the frontiers of Szechu'an, Yunnan and Kwei-cliow he will probably find two kinds of bears, one full grown, the Hsiung, the other smaller and known as the dog bear, Kow-hsinng. Both kinds are black and liave excellent fur, and I hear that their flesh is good eating. These bears are caught when young and tamed without much difficulty; they are tanght to perform and then talien to Hankow and other open ports and exhibited in the ring. The bears on the Tibetan frontier are larger than those in Kwei-chow. Some of the Tibetan bears are said to weigh half a ton, and occasionally one has been killed that weighed as much as a ton. General Mesney relates to me that one evening, in I877, during his first journey in Tibet he and his party camped at a Chinese military station near a forest at the foot of some mountains not far from the Tibetan town Si-tang. During the night the party were alarmed by the sentinels firing off their matchlocks, and on inquiry it was learned that one of the pack nules had been killed and half eaten by a bear which was thought to be one of the larger size, as an ordinary 
bear does not usually venture to attack ponies or mules. I have read or heard of no instance of a white bear having been seen among the Tibetan mountains, although some of these mountains are the highest in the world and are always covered with snow. The color is mostly reddish or rusty looking, and probably the rusty color is an evidence of old age. There was a stuffed bear in the Irama temple, Fin-HoKung, at Peking, which was said to have been Killed by the Emperor Kien-lung, who reigned over China from I736 to I796. The gun used by the Einperor is described as a double-barrelled matchlock, the barrels being octagon in shape and were superimposed instead of round and mounted side by side. This Emperor was fond of sport and died in the lunting field.

Wild Boars (Yeh Chu) or Wild Pigs: This animal may be found in varions parts of China and does not seem to have any special ranges. Almost everywhere I have hunted the natives tell me of wild pigs, and the number depends upon the close search of the native shooter and the accuracy of his aim. The Yangtze Valley appears to be more specially the favorite hannt, and 
there are many wild pigs to be also found in western China. The shooter, while shooting in the Yangtze Valley, will frequently see the signs of depradation committed by the wild pig, as the Chinese perfer to call this animal. Between Nanking and Tatung one may sometimes see fields of sweet potatoes rooted up and the tubers gone; maize and millet fields with their standing crops torn down, as well as half ripe corn. So destructive in some places are these wild pigs that the farmers have their fields watched at night, and in every field or two there is a liut perched on bamboo or other poles some six or eight feet above the ground. In these huts the night watchinan is placed, provided with lighted lanterns, gongs and matchlock muskets. When the wild pigs are heard or seeu the watchtnen beat their gongs, swing the lanterns and fire off their matchlocks; they also shout like madnen, all the noise made with the idea to frighten the depredators away and seldom upon the idea that to kill is the surest guarantee of protection. In some neighborhoods the pig appreciates the situation by quietly proceed- 
ing with his meal. When wounded or surrounded these animals, especially the males, will fight their way to death or to safety, and as if in contempt of the impression that they could be frightened away from a luxuriant and inviting field of cereal they have been known to attack a watch-hut, tear it down and tusk the unfortunate watchman. The old male pigs are said to be specially ferocions, and are aggressive in the maintenance of their right to roam at pleasure. In western China, especially in Kwei-chow, the natives hunt the wild pig with perseverance and courage and delight in the dangers of such a chase. The weapons generally used by the natives are the matchlock, and long bladed spears with short handles, the blades being of tough iron with a fine steel cope. The most convenient places for foreigners to "lunt the wild boar" is in the Yangtze Valley, on the mountains near Ta-tung or even across the river opposite Nanking. Wild pigs are more numerous in upper $\mathrm{Hu}$ nan and lower $\mathrm{K}$ wei-cliow, but those places are $110 t$ so accessible.

Wolves: 'These animals are numerous in various parts of China, and the natives call 
then Lang Chai-lang and Chai-kow. In Kwei-chow and Yunnan two kinds have been seen, but they are not as large as those in Shansi. They liave the reputation of being quite bold in their depradations and will venture into a farmyard or a village in broad daylight to seize their prey. I am informed by one who lias travelled much in China that during a forenoon, as he was travelling in upper $\mathrm{K}$ wei-cliow, he came to a market-place where were assembled several hundred natives; not far off, toiling in a field, he saw a wonlan who suddenly began to cry out and then ran towards him calling loudly Cliai-kow, and at the same time a large brown animal passed near him and ran up the monntainside; it was a wolf. Afterwards it appeared that the woman liad laid her baby near the roadside while she toiled in her field and doubtiess this brute was watching for an opportunity to carry off the child. General Mesney related to me this incident: that on one occasion he was taking a nap on his camp bed inside of his tent when something awoke him and his eyes met a pair of fierce eyes looking at him; the general drew his revolver from under his pillow and fired at the invader 
of his tent and upon examination found that he liad shot dead an old male wolf which had often been seen in the neighborhood. In Kwei-chow and Yunnan the conntry people carry tobacco pipes the heads of which are made of iron or brass and weigh several onnces; these pipes are used as defensive weapons against the attacks of wild beasts. In Shan-tung, Shansi, Honan and Kansu it is a common custom for the conntry people to take with them some weapon of defense, usually a lieavy cudgel, to protect themselves against the attacks of wolves.

On one occasion I was shooting ducks on the lakes near Ningpo, and while standing on a dike which connected two of the monntain ranges two large wolves passed near we and I shot both dead; they fell not nore than ten yards apart. I do not think they saw me until too near to make their escape, although I was shooting with a light weight twelve bore gun loaded with No. 5 sliot.

In China the shooter will find, in addition to the animals more particularly referred to above, the Wild Cat (Yah-11no): the Badger 
(Huan-tzu): the Fox (Hu or Phu-le): the Porcupine (Chien-chn): the Jackal (Chaikow): the Water Otter (Shin-tah), and there are several varieties of Monkeys in the regions bordering on Tibet. It may be said that neither the lion, elephant-(except in southern Yunnan) or Rhinocerous are now met with in China. In the sontheastern mountains near Tibet the Yak or grunting ox exists. 



\section{YANG-TZE RIVER}





\section{CHAPTER V.}

YANG-'TZE: RIVER

Althongh the valley of the Yang-tze is the most populous region of Clina it has long been the favorite shooting ground of the sportsman. The valley takes its name from the river that runs through it and the area of the former is in creditable proportion to the imperial waterway of the latter; and it is the ricliest, and the most favored by the facility of its communications. In this central region of China the Yang-tze river drains an area of 700,000 square miles, and the population of its basin is estimated at $200,000,000$. The climate is temperate and free from the great variations of the north. While the summer is hot the excessive cold of winter is not experienced, and the crops are less irregular than in other parts of the Empire. The agricultural products are tea, rice, silk, wheat, cotton, and buckwheat. The maunfacturing in. dustries are mostly of silk, yarn, cotton, cloth, indian ink, porcelain ware, salt, and oil. Its mineral wealth may be said to be great, but it is less rich in coal beds than 
the north and south. In this region the shooter may find almost every variety of small and large gane. He can enjoy shooting on the nonntains or the plains as the crops cultivated are tempting to both birds and animals.

The source of the Yang-tze river has never been explored, but it rises in the mountains of Tibet and runs a conrse of 3,200 miles before it empties its waters into the sea near the port of Shanghai. In the "Conprehensive Geography of the Chinese Empire" this river is divided by Richard into three principal parts: the first, torrential; the second, semi-navigable; and the third, navigable throughont. By the same high authority the torrential part extends from the sonrce to a short distance above Hsuchow-Fu; the semi-navigable extends from Hsuchow to Ich'ang-Fu; and the navigable part extends from Ich'ang to the sea. The conrse of the river is not influenced by the affuents flowing into it, but by the slope of the land surface. While the Yang-tze river is the central artery of communication there is a net work of navigable streans flowing into it, and the shooter will have no difficulty in 
travelling on a comfortable steamboat for more than I, 500 miles up the river, but he may go farther on in native boats, or he can stop at any of the ports on the river, and with a native or foreign honseboat reach the interior in alnost any direction by means of the creeks and canals which interlace the whole region and often flow from large and beautiful lakes.

If the sliooter goes up the river on one of the steamers leaving Shanghai he can stop at either of the following places, the distance being computed from the mouth not far from Shanghai: Kiangyin, IO5 miles; Chekiang, I65 miles; Nanking, 242 miles; Wuhu, 264 miles; Ngank'ing, 370 miles; Kiukiang, 458 miles; Hankow, 600 miles; Ich'ang, I,OO0 miles; Hsuchow, I,500 miles; and he can make his choice of a steamer belonging to either of the following steamboat companies trading on the Yang-tze river: The China Merchant Steam Navigation Company (Chinese); Indo-Clina Stean Navigation Company (Jardine, Matheson and Company); China Navigation Company (Butterfield and Swire); Norddeutscher Lloyd (Melchers and Company); Hamburg Amerika Linie 
(Arnhold, Karberg and Company); Osaka Shosen Kaisha and Yang-tze Shipping Company (Japanese); Conpagnie Asiatique de Navigation (Racine, Ackermann and Company).

This great river traverses the Chinese Empire from west to east and divicies the eighteen provinces of China proper into two nearly equal portions. Eight of the provinces are sitnated on its left bank with the same number on the south, while the two others, Nanghin and Kiang-su are partly on both banks. I have been as far up the river as Hankow which is 600 miles from its montl, but there is little to be seen of scenery until Nanking has been passed. The approach to Chinkiang is pretty, but after passing Nanking and when nearing Wuhu it is then that the scenery is beautiful on both banks of the river. Often the base of a monntain is washed by the water, and between the ranges of these high liills, which start from the river's edge and run far into the interior, there are ravines which are lighly cultivated ard afford good feeding ground for the pheasant and the woodcock. The alluvial plains made by the deposits of the river will arrest the 
attention of the traveller and convince him that China is not so thickly populated as represented by sonve writers on the subject. He will see plains of the width of several miles and a soil of unequalled productive capacity producing nothing but reeds and grass, but wlich could be made to produce Indian corn and rice in quantities sufficient to feed the population of a sinall nation. Here on these uncultivated plains valuable crops could be produced and centuries of the rich deposits of the great river have fertilized the soil for several feet. Year after year these plains could be cultivated with the aid of very little nature and yet they are utilized for grazing shaggy looking ponies and cattle of the most ancient pedigree and appearance. The reeds grow from 15 to 20 feet high and are larger than a man's thumb. When ripe they are cut for fuel and are often used to build small huts which are frequently seen dotting the plains from the deck of a steamer.

The valley is the feeding ground for wild fowl during the fall and winter months. The river and lakes and valley between Wuhu and Hankow appear as the favorite 
feeding places for wild geese and ducks. There are but few wild fowl below Wuhu in comparison with the number seen above that port, and if the shooter has loaded his gun for wild fowl only he should get on board his houseboat at Wuhu and travel up the river. There are many small lakes some distance from the shores of the river which the geese and ducks haunt. If the reeds have not been cut and the shooter has a loadah familiar with the little canals the farmers have cut from their fields to the river he can reach some of these lakes under cover and he will be well rewarded if he has a steady nerve and a quick eye. Not far from the lakes, as a rule, the land is cultivated and the geese and ducks feed on the young crops; and sometimes it looks as if the whole country was covered with wildfowl. Another excellent feeding ground for geese and ducks is up the Tai-ping-fu river. This river flows into the Yangtze about 20 miles below Wuhu and at the lower end of Wade's island. If the shooter will examine a map of China he will see, some distance up the Tai-ping-fu river, large tracts of marsh land and here it is the wild fowl in great numbers feed during the entire season. 
A bout sunset the geese fly from the marshes to roost in the dry plains, and then if the sliooter is properly concealed he may enjoy an hour of first class flight shooting.

It is not advisable to modertake to shoot wildfowl in the Yangtze river. They always seem unusually wild, and it is almost impossible to approach them within shooting distance. The shooter will be far more successful if he shoots about the small lakes and the marshes, and he should have with him a pair of long legged rubber boots as these will invariably prove convenient.

When the ducks and geese are very clever and can see for half a mile that a gun is not a bamboo pole the shooter can take advantage of such intervals of wisdom and shoot deer and pheasants.

There are many deer in the valley, but they are small and the average weight is scarcely more than $30 \mathrm{lbs}$. Some of them have tusks like a wild-boar and hence the Chinese call them hog deer. They feed on the young grass in the plains and I have seen, from the deck of a steamer, several feeding together. When one is out, specially after pheasants, these little deer are 
really an annoyance at times. During the day they seek the tall grass for resting places and will not get up unless almost stepped upon, and then they run as fast as they can, diverting the bird dog from his work and frightening away the pheasants. These deer are brown colored with thick liair and rather coarse, but the meat is very good to eat. They are easily killed, and the ordinary load of No. 5 shot is ample enough to bring one to bag. Very few have any horns at all, and such as do grow are quite short. There is nothing about them to renind one of the broad antlers and the majestic step of the American forest deer.

I do not know if there is any reason for it, but the pheasants are found almost exclusively on the right bank of the Yangtze. river. Both sides of the river are cultivated, but from some cause they prefer the right, and the shooters who have shot on the left bank have never made very large bags.

The shooter must be careful in the selection of his houseboat for the Yangtze. There he will soon experience that his boat should be more sea-worthy, as the prevailing winds on the river are strong at times and the current swift and turbulent. The lower 


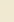




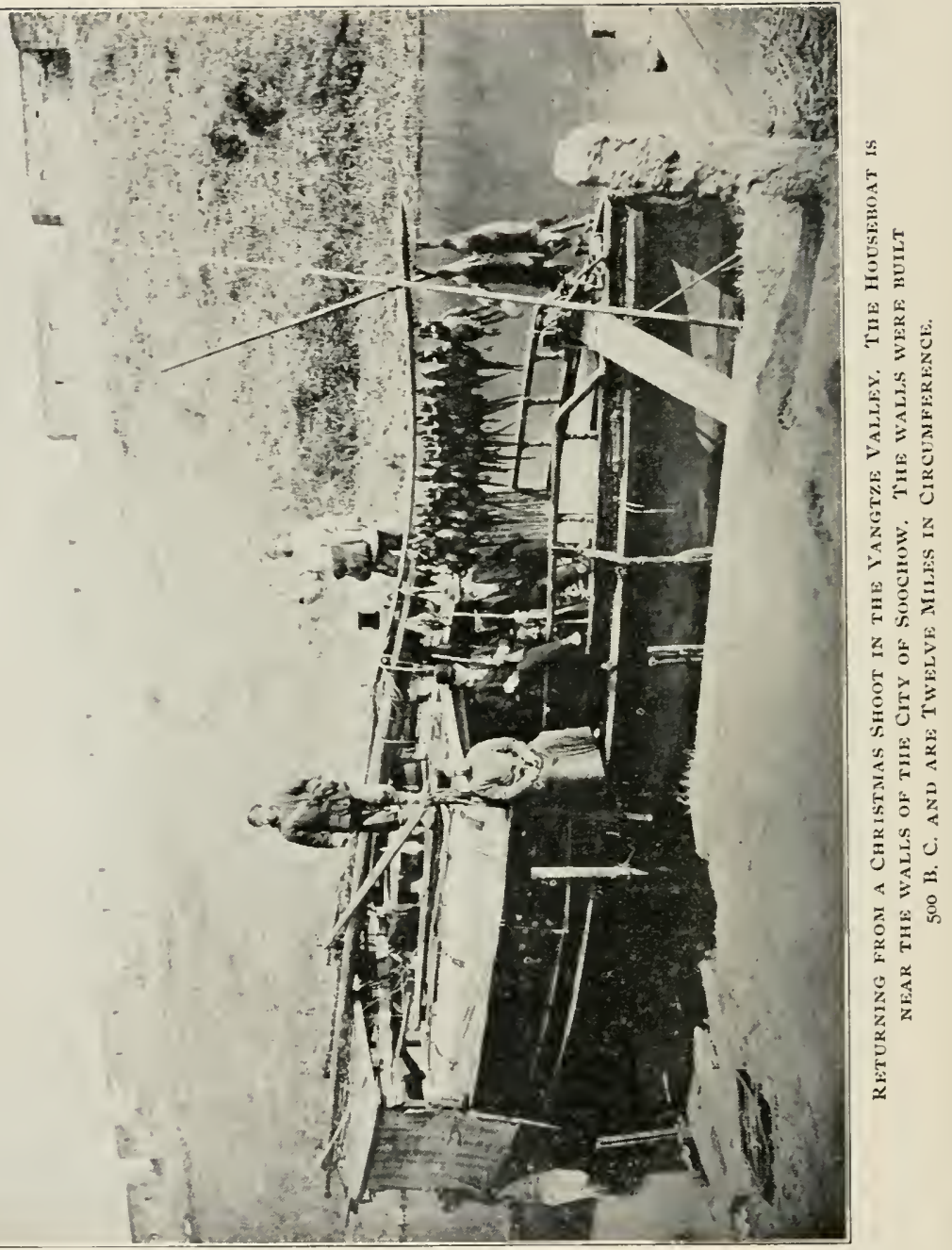


end of the river is several miles wide, and the waves often canse the large ocean going steamships to move nnsteadily. My own experience confirms the above suggestion given me by a friend when he heard that I was preparing for a shoot on the Yangtze river. I well remember that on one occasion if I had not heeded the suggestion I would probably have been compelled to try the temperature of the Yangtze water one cool afternoon in the month of February.

My longest shoot up the Yangtze was in the early part of the month of December. I travelled on one of the large river steamers from Shanghai to Willin, and there a friend had ready for me a splendid honseboat and a full crew. By arrangement the American Consul General at Hankow and his friend met me, and we at once started in separate honseboats for Wuhn creek and yulohed during the night in order to be ou the shooting ground early next morning. The trip was not successful. Nearly all the cover had been cut and the pheasants had left the usual feeding places and we bagged only a few. The trip, however, was not devoid of incident and some amusement. We were shooting in the country back of 
Wuhtu and about fifty miles inland. Our boat loadahs were 11 ot familiar with the country, but before we were aware of the fact they had taken the boats to a place which was not marked on the map and so we did not know where we were. We wanted to enter the upper portion of the Taiping-fu river, travel down it and shoot wildfowl on the way. Fortunately we were near a small town and I suggested to the consul general to send his card to the Clinese magistrate and ask lim to supply us with a pilot. Soon the magistrate called and was cordial and courteous in complying with our wishes. Sails were hoisted and with a fair wind the boats were headed towards the Taiping-fu river. But during the night, my boat being the faster sailer, we became separated, and to add to the disappointment the pilot on the boat of the consul general had a different ilea as to the proper route to the river than my pilot, and so when we awoke the following morning weither of our sails could be seen. We had agreed, however, that Wade's island in the Yangtze should be the objective point, and I believed we would meet again. I spent part of the day trying to stalk geese and ducks, hoping that the consul 
general would overtake me, but I did not see him until the next morning, when I found his boat near mine at the lower end of Wade's island. He came on board and said that I had alarmed the surrounding country and that he had happened along just in time to be held responsible. The alarm was caused in this way: About five miles from the mouth of the Tai-ping-fu river there are two bridges made of boats a hundred yards or more apart. They are for the convenience of the residents of the towns situated on opposite banks of the river, and are made so as to open in the middle for the free passage of junks and other boats. The current at this point is very strong, about three miles an hour, and as my houseboat approached the first bridge I gave notice and the keeper opened the way and as I passed through I threw him a "cumsho". When within twenty yards of the other bridge the proper notice was given but the keeper of this bridge would not open the way. The current was too strong to stop the large houseboat so, with head on, we charged the bridge and took away a part of it. When the collision took place I was standing on deck and the houseboat trembled like a leaf. One 
would have supposed from the noise made by the Chinese that the town on both sides of the river had been pulled into it. The alarm was deafening, but I could not stop nuy boat which continued down the river as under a full head of steanl. About two hours after the bridge had been knocked aside the consul general came along, but one cannot properly appreciate his situation unless he knows something of Chinese character. So far as I was concerned I supposed the incident was closed, but while at dinner I felt iny boat suddenly jar, and upon inquiry as to the cause learned that a large Chinese boat with ten Chinese on board had made fast to mine and that three were on board to arrest the loadah. I at once left the table, took my pistol in my hand, walked to the aft of the houseboat and throngh niny servant boy gave notice that if they did not leave my boat at once I would shoot them down on its deck. But the gleam of the pistol in the lamplight was sufficient, for as soon as they saw it they did not stand upon the order of going. I then asked what damage had been sustained and they thought that six dollars would replace the rope and timber lost. I gave them four dollars and 
they left singing. To have been afraid would have proved serious, not to have been just would have been wrong. If my friend Dr. Wilcox should read this page he will doubtless recall the incident here related, as he will remember the miserable luck we had during the entire trip.

At another time, while shooting on the large island below Clinkiang, I was made to feel uncomfortable for a few moments. I knew that I was in the territory and waters of the Yangtze pirates but as usually happens game is more abundant near such places. It was a dark night and I was reading when I felt the jar of a boat against mine and immediately after two men jumped on the front deck. As I looked up I saw through the glass panel in the door that one of them wore a sword. The scabbard distinctly gleamed throngh the glass, and my servant boy who was near became nervous. I was alone but neither of the men had seen me, and I placed my eight bore fowling gur, each barrel loaded with $2 \mathrm{r} / 2 \mathrm{oz}$. of buck slot, convenient, as I did not intend to be robbed and carried off a captive by Chinese river pirates. Soon one of the men stepped in front of the glass panel and I saw that he 
had on the uniform of a Chinese naval officer. I put a pistol in my pocket, opened the door and asked his business. He was a bright and clever looking young officer, graceful and courteons in manner, and answered that he liad been sent by the commanding officer of a Chinese gunboat, anchored about a mile away, to advise me wot to go any higher up the river during the night as it might prove unsafe. He added that they had seen me shooting on the island during the day, and had orders to apprise me that the neighborhood was dangerous after sunset. I invited him to a seat in my cabin, had a pleasant cliat with him, and intimated that, with his consent, I would move my boat near his gunboat, to which he readily assented, saying that the commanding officer would be pleased if I did so. I was not afraid, but somehow I got pirates on my mind and I had no objection whatever to being near a gumboat. When he left he remarked that he would go ahead and run up a light so that I could distinguish the gunboat. The night was quiet and I slept soundly, and the thoughtful and friendly consideration of this Chinese naval officer is pleasantly remenbered. 
I have not found the Yangtze valley the paradise of the sportsman" as some writers have described it. My most successful pheasant shooting has been in the inland country, where rice, peas, and buckwheat are the principal crops and where the fields in which these crops are cultivated are near the low lying hills and mountains. On the Yangtze I have nade larger bags when shooting near the patches of reeds that grow between the river and the cultivated fields. After the morning feed the pheasants are fond of resting, during midday, among the reeds, and one can walk along the dykes and get in some effective rights and lefts if he has a well trained dog. The ravines that make inland from the river are also the favorite resort of the pheasant and woodcock. If the tide in the river is high the shooter should engage a sinall boat and go up the little creeks that fiow into it. Often he will find on both sides pheasants and woodcock, and these are slow to rise from such coves and restful places. Another resort for pheasants is on the hillsides where the acorn bearing scrub-oaks grow. They are fond of acorns, the walking is not very inconvenient and the oaks are not tall enough to 
obstruct the view of the shooter. These oak groves are also the resting places of the deer, and at the foot of the hills wherever the gronnd is moist the dog will occasionally put up a woodcock or snipe. The experienced shooter well knows that the pheasant changes his feeding ground quite often. Thie places that knew him in abundance one season will not know him the next.

The sport I am now writing about is far more healthy and exciting than that of shooting driven birds. The system of agriculture in England renders almost necessary the latter as the only way of shooting pheasants, and those are not bad marksmen who can bring down a high flying pheasant whether driven or otherwise, but the endurance and skill of the shooter are better tested when, with guu and dog, he finds this game bird on his native hills and plains. Here there is full liberty for each. No taming process has dulled the vitality of the pheasant, and when he rises his flight is masterful and strong. There is no sympathy that the bird was raised near a barn-door and is driven over the guns while the shooters sit at ease on 
stools. There is the knowledge that he is untaned and the feeling that it is a fair trial.

Whether the bag be large or small it is pleasant to shoot in the Yangtze valley. There is something in the flow of the great river that stirs the mind to active reflection. Its source is among the monntains which form the roof of the world, and for centuries it has borne on its bosom a valuable share of the conmerce of China. Its valley must indeed have been the "paradise of the sportsman," but since the advent of the westerner with his steamboats and hammerless guns the shooter when he now steps ashore should wear lis best fitting hunting boots, for he will have to walk long and look well for his pheasant. The inlabitants of the valley are peaceful and friendly inclined, and there need not be any trouble if one has a few Mexican dollars in his pocket and knows in what size doses to administer such medicine. 



\section{CH'IEN-T'ANG RIVER}





\section{CHAP'TER VI.}

CH'IEN-T'ANG RIVER.

In January 1906 I shot in company with two friends on the banks of this river which is the most important of the fourteen principal rivers in the province of Chekiang, and a diary kept at the time is before me as I write. I have thought that possibly my reader would receive a better idea of this shooting ground if I placed before him the impressions made upon me and the experiences through which I passed.

I shall never forget iny shoot on the Ch'ien-t'ang river. I an sure that I touched all the extremes of vexation and that the very best boat on this river was specially built for discomfort, yet, there are many incidents which it is pleasant to remember as well as to serve as warnings against the numerous mistakes that were made.

My shooting companions and I had understood that the banks of the river were "virgin shooting grounds," and on the first day of January I906 we got on our houseboat at Shanghai and were 
towed by a steam launch to Hangchow, which is situated at the southern terminus of the grand canal and one hundred and fifty miles from Shanghai. Arriving at Hangchow it was necessary to transport our baggage and shooting equipments several miles across the country before reaching our boat on the river which the courtesy of friends at Hangchow had previously engaged for us. And now the diary begins with such comments interspersed as the occasion and the state of mind prompted.

As it was 8 p.m. when we arrived at Hangchow we slept on our houseboat the first night, after preparing for an early start next day. When we awoke the clouds were lianging low and heavy, but we did not delay on account of the weather ontlook and at once began to pack our effects in sucl shape as they could be easily carried across the conntry by the coolies engaged for the purpose. By I I a.m. the coolies had started, but we took a different route and one that led us direct to the lake near Hangchow. I had never seen this lake, but had read many descriptions of it and soon realized that its beauty and the restfulness 
of the surrounding country had not been overdrawn. We engaged a small boat, crossed the lake, and after walking through the country for about $3 / 4$ of an hour we came to the river at the point where our boat was anchored. The coolies with our effects were there waiting for us, and we at once took possession of our new boat on which we had arranged to live for at least 20 days; and here was our first vexation. We supposed that the hire of the coolies for carrying our effects across the country would not exceed five dollars, but when we looked around and counted the number engaged we paid the twenty dollars demanded rather than lave a row at the outset of our expedition. As we understood that foreigners were not in the habit of shooting in that part of the conntry it was quite clear that the Chinese were taking advantage of the three strangers who had come among them. And yet one of these strangers was born in China and the other two had lived many years in the Empire. There was no reason why they should have allowed themselves to be thus imposed upon. Had we acted as a little common sense would have dictated we would have arranged 
every price in advance and have had it set down to the "cash" the sum to be paid. However time was passing and no one knew it better than our Chinese creditors who were pressing for immediate payment.

As soon as our effects were put on board of the boat we had engaged and we had given the word to weigh anchor the loadah refused to sail unless we paid him fifty cents per day more than the sum we had just agreed upon, which was two dollars and fifty cents per day. Ratlier than be delayed any longer we added the fifty cents believing that it would compensate for the night work we shonld require, and finally the boat left lier mooring with her bow pointing to the opposite bank of the river. At last we supposed that an actual start liad been made for the virgin shooting grounds. The current of the river was against us and as we were going up the stream the progress of the boat was very slow, being propelled by two long slender oars used for yulohing. But the surroundings were interesting. We had never been on the waters of this river, and just before the evening shades the sun streaked the western clonds with golden brightness. 
We felt as if tomorrow would be a bright day for shooting and we began to put our guns in order and select the cartridges we should need for pheasants and woodcock. The opposite shore was reached in the early part of the night and the boat made fast for the crew to eat their dinner and for the cook to prepare ours. Our intention was to proceed up river during the night and when the order was given we soon perceived that our crew had decided not to obey it but to go or not go whenever they wished. We again made a mistake and humored them and so rested for the night, thinking that the country aronnd might be suitable for game. Early the following morning we went on shore but soon returned as all the cover had been cut and there could be but little if any game where we then were.

This was January 6 th., and we were under way by 8 a.m. About Io a.m. we stopped at the city of Mo-ka-nie and sent the boy ashore to purchase some kerosene oil. It was while stopping at this city that we first fully realized that the loadah and the crew were the most obstinate fellows ever found on any boat, and that they had made 
their minds to command and dictate when and where we should go. After exliausting all diplonatic nneans, and being convinced that the sole object was to extort additional compensation, day after day, I sent for the loadah and read the riot act to him. In another chapter I have advised the shooter that when the loadah of his houseboat became sullen and n11willing the best course was to put him ashore, and so I told this loadah that if he did not mend his ways he should at once be put on shore. Doubtless he informed the crew of my threat and soon we saw that all, loadah and crew, had conspired for the crew to go ashore and the latter were actilally prepared to do so. But we gave them a word of positive command, with a look that showed what we meant, and the conspirators soon appeared quite humble. Proceeding up the river, we saw a place that looked favorable for shooting, and at 2 p.m. stopped the boat, and with dogs and guns made our first appearance on the banks of the river in shooting uniform. There was no game here and we returned to the boat at 7 p.m., weighed anchor and gave orders to go up 
higher. The crew refused to obey, and one of us remained awake most of the night to enforce the order.

On the morning of the 7 th., the boat was at anchor near the city of Fu-Yang. The day was bright and the air clear and invigorating, and notwithstanding the annoyances caused 115 by our crew we still were hopeful that all would end well, and we gave ourselves up in admiration of the scenery. On a hill, shaded with somber looking trees stood a temple, built near the river as if intended to appease dragons which, when incensed, the natives say would lash its waters into fury. Near this city we went ashore, on both sides of the river, and although the cover was all that could be desired the pheasants were very scarce.

We were still in bad luck, but we were only at the beginning of our plan of campaign, and our nuinds were fully made up to see the end of it. As twilight came on there came with it a refreshing wind from the direction of the bay and directly up the river in our favor. The sail was loisted, and under the impression that the boat would sail on for the night I retired 
to my bunk for a nap. I had not been long asleep before I experienced that the boat was either sailing unusually smooth or had stopped. I immediately got up to learn that both of my friends had agreed with the loadah that the wind was blowing too hard and that it was prudent to anclior. I went on deck; the moon was riding in a clear sky and her silvery light brightened almost with the brightness of day the water and the land about. There was a delightful breeze and I directed that the anchor be pulled aboard and that the sail be thrown to the wind, and soon we knew that the boat was capable of bearing her canvass and was moving ahead at the rate of five miles per hour. When time was so essential, we had lost several hours by the laziness of the loadal and the fear of my friends of a bath in the river on a January night. I pointed them to the example of the bee and the honeysuckle and advised them to study the way of the ant, tried to impress upon them that courage and perseverance were the virtues that won success on every arena of life. At no other time of the trip did I find them afraid of the wind or of a batin which we all very mucl needed. In this 
connection I thonght of these lines from Horace :

For thus the little ant (to human lore No mean example) fornis her frugal store, Gathered, with nighty toil, on every side, Nor ignorant, nor careless to provide For future wants.

Yet, when the stars appear That darkly sadden the declining year, No more she comes abroad but wisely lives On the fair store industrious summer gives.

The Sth., gth., and Ioth., were spent in surveying the country, as it were, for after the closest search, and mile after mile of walking over hills and mountains and the little plains between them, we had failed to make a bag approacling respectability and we retired, on the evening of the roth., under a downpour of rain and in the face of a heavy gale. The boat was anchored in the shelter of a side creek, near a village called Chong-ka-poa, and there we remained until the weather was more promising and then got under way. On the morning of the IIth., we anchored opposite Psiangka-poo. Early in the afternoon another attempt was made to find some pheasants, but they were not to be found. The cover of the country we had hunted appeared excellent, and the rice fields between the 
mountains would seem sufficient for feeding purposes, but thus far we had bagged a few only, and as we expected to add to our commissary department by our skill as shooters, prudence dictated that we liold a conference in the interest of the econonny of our table. We were feeling quite despondent over our luck, but we were not wholly discouraged, and on the morning of the r 2th., we started higher up the river, but the current being very strong against us we anchored at the entrance of the gorge. While here we had a full view of the beginning of the magnificent scenery aliead. The nomntains rose almost perpendicular on both sides of the river and their tops were covered with snow. While waiting a fresli wind began to blow up the gorge, and availing otirselves of it we hoisted sail and soon found it steady enough to drive the boat ahead, although the current continued strong and swift against us. The scenery througl which we passed was really beantiful. I do not know that I ever saw prettier. Soule of the monntains were shaded with large pretty trees, and the temples and villages built at their bases or on their sides seen to give a repose to 


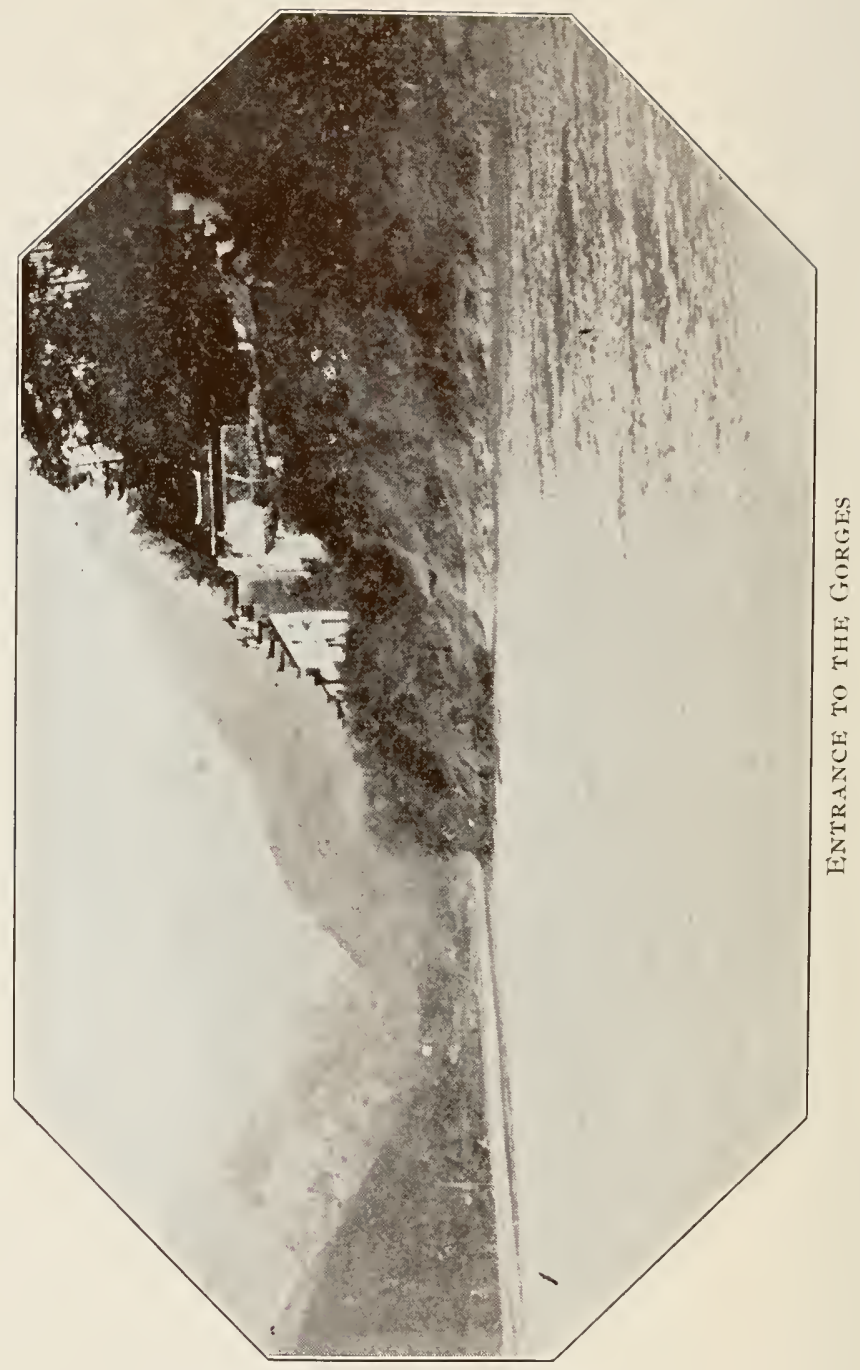


the grandeur of the landscape. At 2 p.1n. we were near the city of Nitze-fu, when the boat was stopped on a flat in view of the city, which was the largest yet seen wlile going up the river. With our glasses we could see that the country around afforded plenty of cover and we began to recover our spirits with the hope that success would ultimately crown our efforts. We retired early with all the stars shining brightly above and for the first night slept under the influence of even tempers and pleasant dreams. Farly the next morning, being the 13 th., we were in the field fully equipped for the day's sport, and while it was, practically, the first full day's shooting we had enjoyed, it was also the first day we liad had any substantial success. The boat was inoved ligher up and nearer to the city, which has a pretty location between the river and hills, and the shooting in the afternoon also proved good. We found most of the pheasants on the right bank of the river. The natives said that there were many wild pigs among the mountains and one was seen, but too far off to shoot. We were beginning to feel 
that we were ourselves again when we returned to the boat for dinner. Our bag was not very large, but we were improving and our hopeful spirits had come back to us.

The I 3 th. was a lovely day. The water was as clear as I ever saw it in a river, and the city seemed to sleep in the distance, while the surrounding mountains upheld the soft hazy atmosphere, which reminded us so much of spring. I stood on deck for some time and looked long at the two pagodas which topped the hills, one on eacli side of the river, and which appeared to give softness to the whole scenery. The native boats, engaged in commerce, were passing in different directions, and the farmers were busy in the fields. And thus it had been going on for centuries, and the people were satisfied. Our sleep had been refreshing the previous night and our thoughts were charitable. We did not admit the right of the westerner to disturb the contentment we saw by the intrusion of hinself and his ideas. Why go and tear down the ancestral temples at whose shrines four linudred million peoples have worshipped for thousands of years? Was not Carlyle 



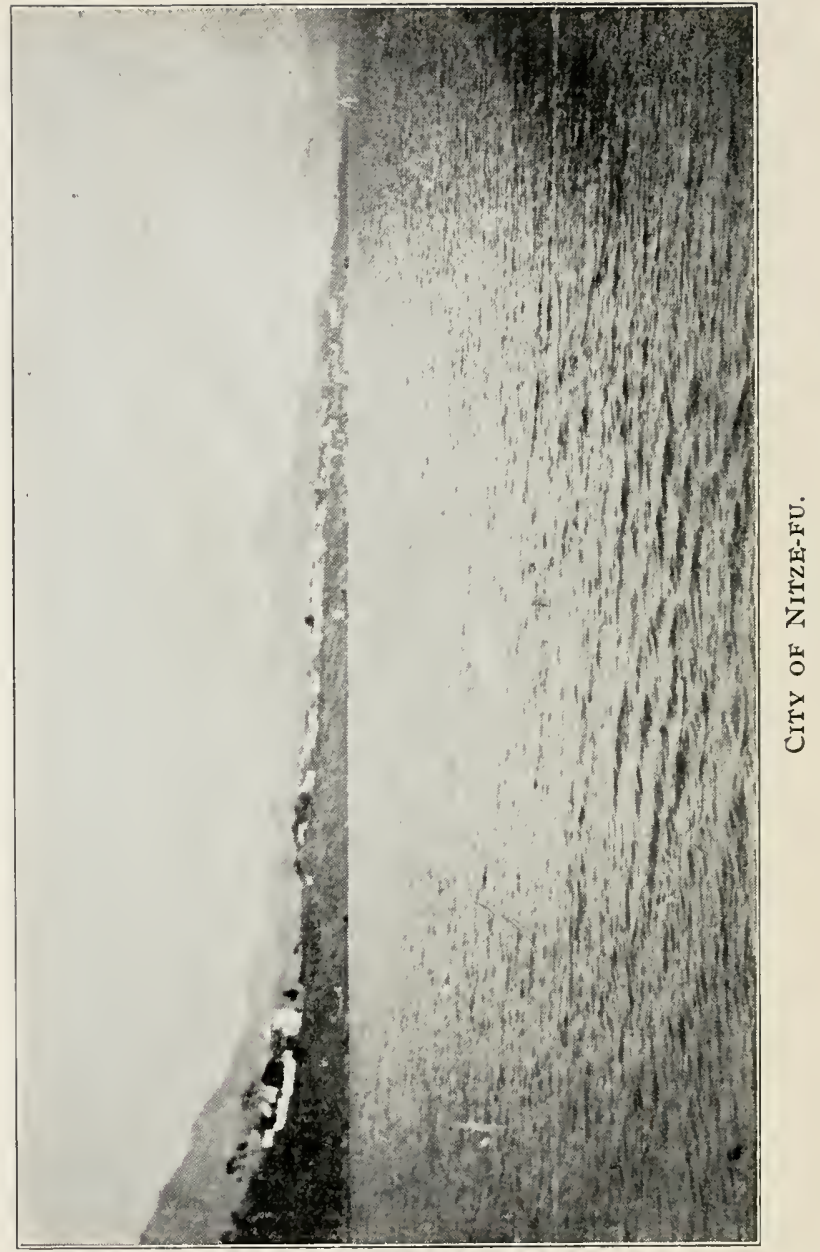


right when he said there must be something in all that? But on the I4th, about noon, we were convinced that onr philosophical mood would have to give way to one more practical. After a morning shoot we returned to the boat about noon and found that the entire crew had deserted. When we saw that our situation was getting desperate we at once adnitted that some reforming agency, in the interest of fair dealing, was imperatively needed in China It appeared that the loadah liad been in arrear to the crew for several weeks, anci after they had succeeded in getting what was due they would not remain on the boat any longer without security for the future which he could not give. Had we known of what was going on the trouble could have been avoided. There was nothing to do but remain where we were during the night and to find a district magistrate the following morning and place our case before him. Early next morning we sent a boy to find a magistrate, and soon there came two Chinese from his official resiclence. We were told that the magistrate would receive us, and so we put on our best shooting clothes and made an early start for his 
Yamen, the name for the official residence. We had been sitting in a room for a few moments when a very pleasant young Chinese entered and said that the magistrate would be in very soon. During the interval we had some conversation with the young gentlenian and noticed that he spoke English plainly. I inquired where he learned to speak the English language, and he answered that he had been tanght by Dr. Gilbert Reid at Peking. I then told him that we all knew Dr. Reid, and he expressed pleasure in meeting us and said that the magistrate was his father and he knew would be glad to convenience us in every way he could. Soon the magistrate came in, a fine looking specimen of the Manchu gentleman, and he made us feel at perfect ease. After the situation had been explained, he promptly replied that we should have a new crew and that he wonld have those who had deserted arrested. I thereupon said that we were shooting for pleasure and did not wish to cause tronble or to be troubled, and that if he would have us provided with a competent crew we did not care to see again the fellows who had deserted. After drinking tea and eating 



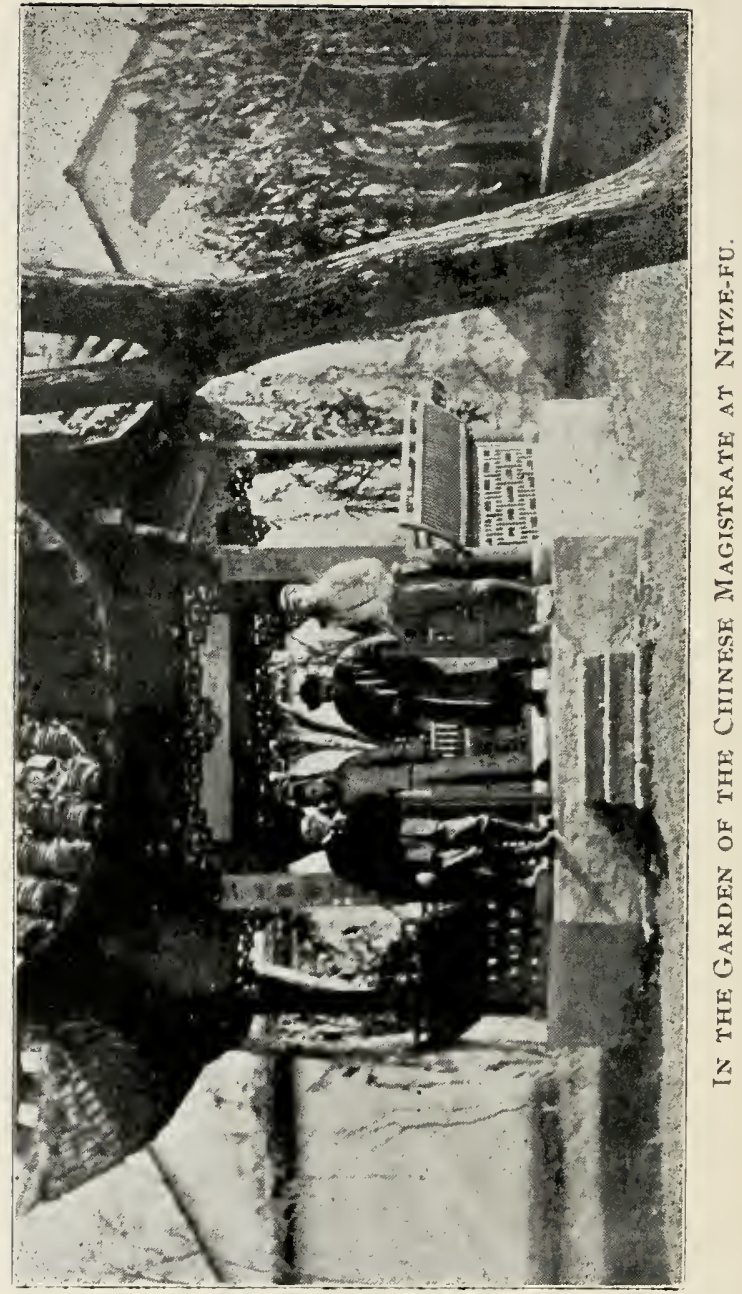


cake, we intimated that our expenses had been larger than was expected and that our silver was exhausted, though we liad sone paper money on a Shangliai bank. He directed one of his clerks to exchange the paper money for the amonnt we wanted in silver, and this was done. Before leaving this courteous gentlen11n and his interesting son, one of my friends took their photographs, as they stood together in the door of a small pavilion in the yard of the Yamen. All the Clinese officials I ever met, under similar circumstances, have been obliging, but the magistrate of the city of Nitze-fu won our respect by his dignified bearing, and our gratitude and friendship by the pleasing manner in which he relieved our distress and wants. Soon after returning to the boat, the new crew cane on board and we spent the remainder of the day in shooting on both sides of the river, but with little success. It was now the I 7 th., and we must soon return. The boat was moved about four miles above tire city, when navigation became very difficult on account of the low water and sand bars. The cover at this point was good, but there were many native sportsmen who supplied 


\section{I76 SHOO'TING IN CHINA}

the city witl game and pheasants were not plentiful. In the afternoon between 3 and 5 o'clock, my dog found ten pleasants and I bagged seven. Our boat, being rather large to go much higher up the river, we decided to turn her bow towards Hangchow, and on the ISth., we again anchored near Nitze-fu. The new crew provided us by the magistrate were engaged for the up river trip, and when we returned to Nitze-fu we had to enter into another agreement with them to take the boat to Hangchow, which was effected without delay. The price was two Mexican dollars per head for the trip. After shooting on the right bank of the river until about noon, we pulled up anchor and started for Psiang-Ka-poo which we reached, thanks to a fair wind, at 5.30 in the afternoon. The weather was quite warm and we expected more rain, but when the Igth. cane there was instead of rain a strong adverse wind which steadily blew during the entire day, and we remained at anchor until the 2oth. But notwithstanding the cold wind we went on shore and had fairly good luck. The cover was very good, but we had been anticipated by the native sportsmen. On the morning of the 2 oth we 
resumed our journey towards Hangchow. Soon after lunch the weather cleared up and we went on shore again. We did not succeed in bagging a single pheasant but the scenery was lovely to look upon. There was an apricot orchard of fully seven acres on the left bank of the river and near to the place where the boat was anchored. The trees were in full bloom and the air was heavy with the fragrance of the blossoms. It was at this place that we saw so many pretty holly trees in shape and size and we cut a few and brought them aboard. The wind was still blowing a steady gale, but we weighed anchor and pushed on toward Hangchow. On the 2 Ist. we made an early start, and although it was raining heavily, the wind being in our favor we made some progress and passed Fu-Yang about II a.m. When night came on the loadah demanded more money, but soon after we refused to be thus imposed upon he deliberately ran the boat on a sand bar. For this wilful act he was made to feel the full consequences. Most of the crew were willing and did what they could to move the boat into deep water, but the loadah lit his opium pipe and was preparing 
for pleasant dreams. We called him on deck, compelled him to disrobe, and made him jump overboard wliere the water was waist deep and as cold as a January night could make it. Nor was he allowed to be idle. We made him put his shoulder against the boat and kept him exercised at his work for a quarter of an hour. But he had run her so high up on the sand bar that it was then impossible to remove her and we waited until the following morning when we succeeded in getting off. When the loadah cane on board from his cold batl he poured hot water over his feet and legs, wiped the water off with a rag, lit his opium pipe again and in an lour was sound asleep. But I do not think he will ever again land his boat on a sand bar when there are foreigners on board. The following day he was quite obedient and willing. In this connection I recall another instance when a little force proved beneficial, but it took place when the boat was some distance up the river and before we started back to Hangchow. We had been noticing that the loadah, who was an inveterate opium smoker, was under the influence of one who turned out to be his brother, but who exer- 
cised the authority of a loadah. It was this fellow who was constantly applying for advance and extra pay. He proved the disturbing element anong the crew and was continually delaying the boat to our great annoyance. One morning early this scoundrel came into the apartment in which we slept, and in a bullying manner began to repeat his demands. I was lying in my bunk and ordered him out of the room. With an insolent bearing he walked to the front door of the boat, opened it wide, and stepped out on the bow without closing the door. The wind was chilly and blew into my face. I jumped out of the bunk, went on the bow where he was standing and inciting the crew not to work, gave him a good shaking up until he agreed to go to his work, as it was his duty. We had no more trouble with this scamp, and the first village we arrived at after the occurrence he was put on shore and not allowed to come on board any more. On the $22 n d$., we were at Hangchow, and it was raining and snowing and the weather was very cold. We were compelled to remain at Hangchow until the following afternoon, and were the guests of that courteous gentleman, Mr. 
Smith, the British Consul at that port. We arrived at Shanghai on the 24th., about 4 p.m. with a full bag of experience, but with seventy-two pheasants only.

The boat we lived in for more than two weeks may be described as follows: It was built of ordinary Chinese pine timber, and the boards were oiled so as to keep out the water. The length was nearly fifty feet, the width, at the middle, was in proportion to the length, but the stern and bow were pointed and both high up from the water similar to a Venetian gondola. There were two bunks on each side, made of hard wood, which could be felt through a mattress a foot thick. Beneath the floor to our room was a sleeping room for the crew, and between the flooring planks there were open spaces so that the smell of a Chinese sleeping room came up into ours and settled around our bunks like a fog. The after part of our sleeping room was open and we were fully exposed until we found a piece of old sail and partly closed it, but this did not keep out the wind. There was a door in the front part, but the top of the boat was so constructed as to prevent the loadah from seeing how to steer unless it was kept open. We, 



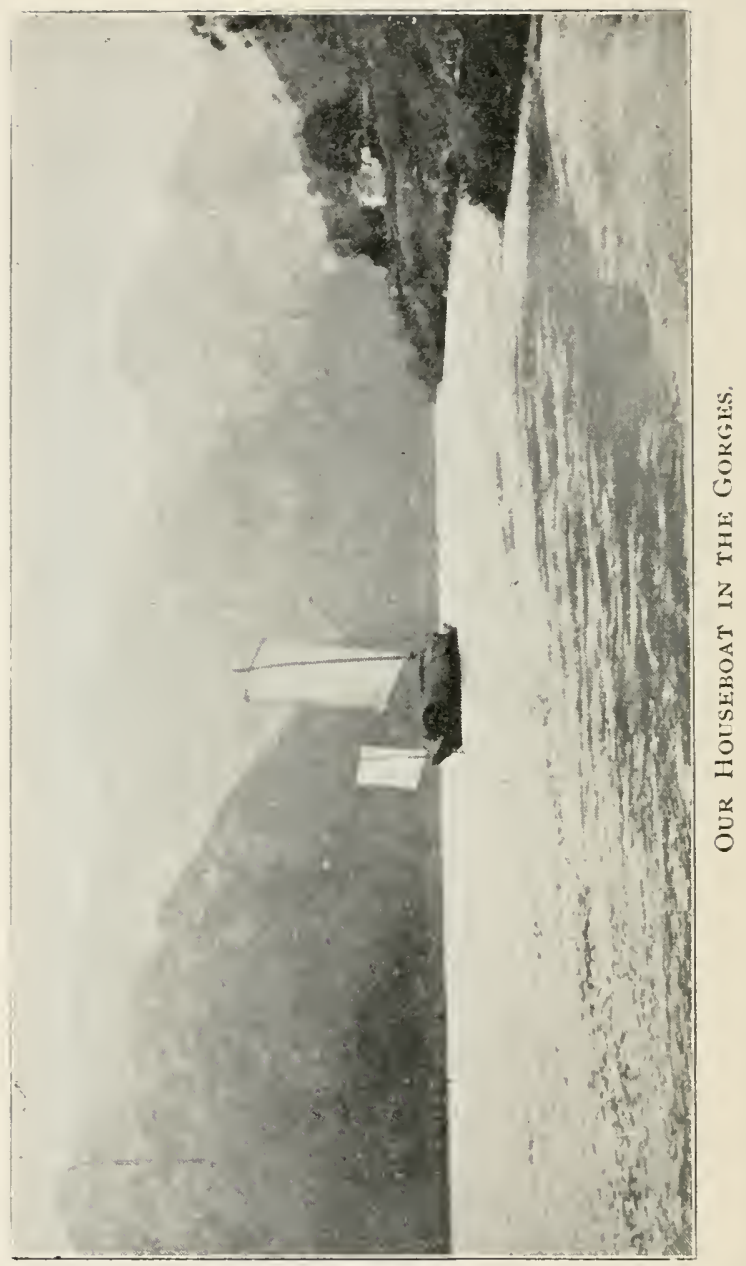


therefore, had to decide between freezing and the risk of not going straight, and we took the latter. The top or cover to the boat was made of thin slips of bamboo between which were nicely interwoven large leaves of some kind, and this proved almost impenetrable to wind and rain. But on at least one occasion, the rain came down in torrents and we had to dry our bed-clothes as best we could. On another occasion we were overtaken by a snow-storm, which covered the ground for several inches deep and filled the ravines between the hills. The cooking was done in the aft of the boat on Chinese stoves, and if we had not, fortunately, brought with us two oil stoves there would have been no means of kceping our room even moderately warm. It was so dark when we were aboard, with the door necessarily closed, a lamp was kept burning nearly all the time. The top, which is ingenionsly constructed, is held fast to the hull of the boat by means of wide bamboo slips, some extending from side to side like a hoop and holding down others which are placed lengthwise the boat. The fastening is quite secure and at no time did we fear that the top would blow off, although we 
passed through more than one severe gale of wind.

If I should ever again decide to shoot on the Chi'en-t'ang river, or to revisit the places I have named above, I should take with me several yards of thick canvass, a medium size rug, a cooking stove, a small heating stove, and certainly a folding bedstead and mattress and warm blankets. If we had had these articles our trip would have been far more comfortable. I do not suppose it would be possible to engage a boat better than the one we had, and as a proper houseboat could not conveniently be carried several miles across the country and put into the river, let the shooter, who goes where we did, be sure to arrange in advance every detail with reference to his boat and crew, and to have the agreement in writing and signed in the presence of some Chinese official. Such a course will save him a great deal of trouble, and I would advise him to make the trip during the latter part of November, as undoubtedly we liad delayed too long.

The country in which we had been shooting was mostly agricultural. There were some beautiful plains on the right bank of 
the river extending as far back as one or two miles before reaching the ranges of mountains which were always in full view. The crop on this bank was principally wheat. In some places the fields were bordered on one side by the shore of the river and the wheat was cultivated near to the water. It was then about three inches high and looked very promising. In some of these wheat fields, dotting here and there, were oak groves the trees of which were of uniform size, not large, but tall and appeared to receive special attention from the natives. The plains were not so wide on the left bank, and it was on this bank that we observed that rice was mostly cultivated. The mountains were, as a rule, nearer to the river, and the narrow plains between them were selected to grow rice.

There were large paper industries near some of the cities and towns we passed or visited, and the natives in the country seemed to be also engaged in making paper. The product which we saw was a coarse, brown material and which we understood was shipped in large quantities to far off markets. When the sun was shining briglit and warm sheets of this paper were spread on the sides 
of the lills and in the plains to dry. When ready for the market it was gathered and packed into sinall bales convenient for handling, and we saw large boats loaded with it sailing towards Hangchow, which appeared to be the largest market for sale and distribution.

Another industry was the gathering of small sticks of wood and baling them for shipment. At many places on the banks there were quantities of these bales awaiting buyers or boats for the markets. It is quite an industry and one in which the services of childiren are profitably employed.

There are a few small steam launches on the river the depth of the water being mostly shallow. The commerce of the river is carried on, as a rule, in native boats of various and suitable sizes, which are propelled by yulohing, or by sail when the wind is favorable.

We saw some pretty fruit orcliards. At the proper season of the year fruit is plentiful, and we learned of good flavor. The apricot seemed to be principally cultivated, but the peach and plum grow to 1naturity, and are sweeter than those grown nearer to the sea or the bay. 



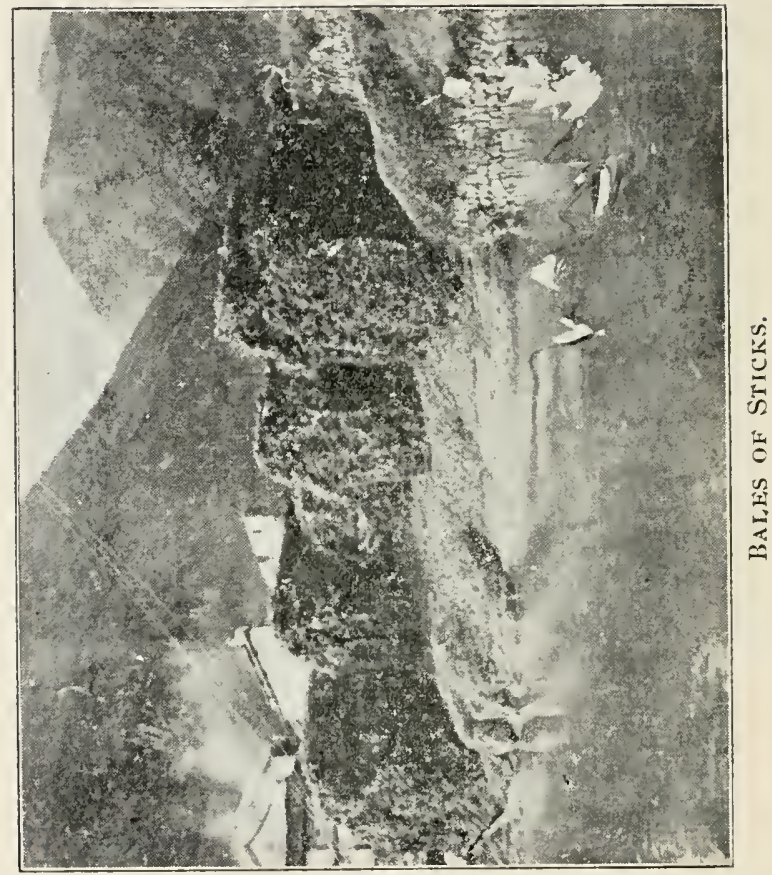


The people are not wealthy, and this is evidenced by occular proofs of the value of their river commerce and the size of their fields and their small industries. But they impressed us as being contented and satisfied with their lot.

During the interview with the magistrate I said to him that he presided over a beautiful district and I thought he had little or no trouble in governing as the people looked happy. He replied that the people were not difficult to control, but that they were poor and took life easy.

The province of Chekiang is the smallest of the eighteen provinces of China. The province is poor in minerals, but agriculture is in a prosperous state and the productions from that industry are valuable, more so on account of the net work of navigable streans suitable for native commerce. The part of the province lying south of Tayu-ling is mountainons, but between Ningpo and Hangchow, and to the west and north and northeast of Hangchow are large and fertile plains. The central and upper regions are mountainous witl broken and picturesque hills, and some parts of the western region are fairly well wooded. The agricultural 
products consist chiefly of tea, rice, silk, cotton, indigo and fruit.

Hangchow is the principal city of the Chekiang province and contains about 350,000 inhabitants. It is now a treaty port, and at one time was considered the finest and most favored city of China. Situated on the left-bank of the river, and near the famous west-lake (Si-hu), with graceful hills to its rear, the city is still beautiful in its situation, and one can easily appreciate the glowing accounts given of it by Marco Polo and subsequent writers.

During the Taiping rebellion it was almost devastated and has never recovered from that act of vandalism. In 1905 the total net value of the exports and imports was Taels $I 7,496,980$.-Hangchow was the capital of the Chinese Empire during the last half of the Sung dynasty, A. D. II 27I 280 . 
LAKES NEAR NINGPO. 


\section{CHAPTER VII.}

LAKES NEAR NINGPO.

My first shoot in China was on these lakes. The lakes are about 20 miles south east of the city of Ningpo which is situated on the Yang-kiang river and $x_{5}$ miles from its mouth.

If the shooter starts from Shanghai the journey should be comfortable all the way, and there will be no delay, after his arrival at Ningpo, if he will arrange for a houseboat in advance of his going.

On every day, Sundays excepted, a large and comfortable steamer leaves Shanghai for Ningpo and Ningpo for Shanghai at 4 p.m. and the distance is only a $\mathrm{r} 2$ hours run. But after arriving at Ningpo it will be necessary to secure a houseboat in order to travel to the lakes, and, therefore, the precaution should be taken to engage the boat a day or so ahead. If this arrangement is made the shooter will find at the steamer's wharf a properly fitted up houseboat with a competent crew and ready to leave at once. After he has put on board his equipments the houseboat is then yulohed a short distance up the river 
when, by means of a most primitive windlass, it is pulled over the river embankment into the creek which leads to the lakes. If the start from Ningpo is made immediately on the arrival of the steamer the lakes should be reached at I I a.m., giving time to have lunch prepared and the entire aftermoon for shooting.

If the shooter wishes to take his houseboat into the lakes the loadah will inform him which branch of the creek to travel, but unless the weather is warm it is advisable to stop the boat near the lower end of the lakes and in the creek, and he will be within a few hundred yards of the best feeding grounds for ducks. As the lakes are small, and in reality make but one sheet of water, the houseboat looms up quite largely in contrast to the small canoes which are in use by the fishermen and farmers of the surrounding country.

My first day on the lakes was a bright and calm day in the early part of November. I entered by way of the upper end, and by the use of another primitive windlass the houseboat was pulled out of the creek into the lakes over a high embankment which divides the two waters. 



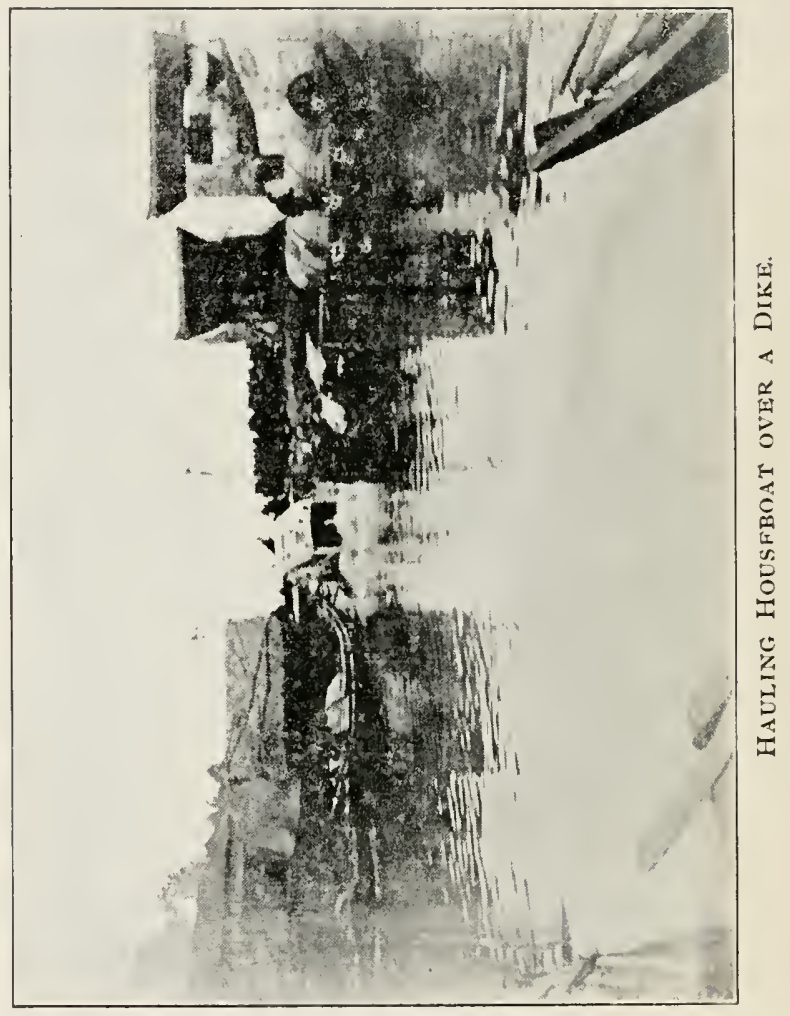


All around there were high hills and mountains, and as there had not been much rain the water in the lakes was clear and the bottom could be easily seen covered with the grass the ducks are so fond of. The sides of many of the liills and mountains were terraced and beautifully cultivated and the industrious farmers were busy at work. Sometimes I could see an entire hillside, green with vegetable growth, reflected in the water. So clear could all this be seen that it looked as if the farmers who were moving about between the turnip and cabbage rows were walking on the bottom of the lakes. There are several villages built on the narrow plains which separate the hills from the water, but the inhabitants are peacefully disposed and the shooter can easily buy all the vegetables, eggs, and clickens he may need. I have been shooting on the lakes for several seasons and have always found the natives friendly. The best sweet potatoes I have seen in China were grown on a small island in the lakes. The principal products are vegetables, which are sold in the Ningpo city markets, and early every morning the creeks leading 
from the lakes and the surrounding country are covered with small boats, loaded with vegetables, and bound for the city markets. Another industry is the granite quarries, which are worked by a large number of the natives, and the rock slabs which are there prepared find ready sale in the markets wherever offered.

When the shooter arrives at the lakes, he engages a small boat large enough to move about steadily with himself and another man on board. He will have no trouble in engaging such a boat, for as soon as his houseboat is anchored there will be several around it for employment. But he should be careful to get a boat whose owner knows something of the habits of wildfowl and how to approach them. In the early part of the season the lower end of the lakes is covered with rush grass which grows three or five feet high above the water, and in this grass the mallards mostly feed. At times it is difficult to push the boat through the tall and thick grass, but if the native owner knows his business he will be faniliar with the many little openings through which he can quietly propel his boat. He sits in the stern with a bamboo 


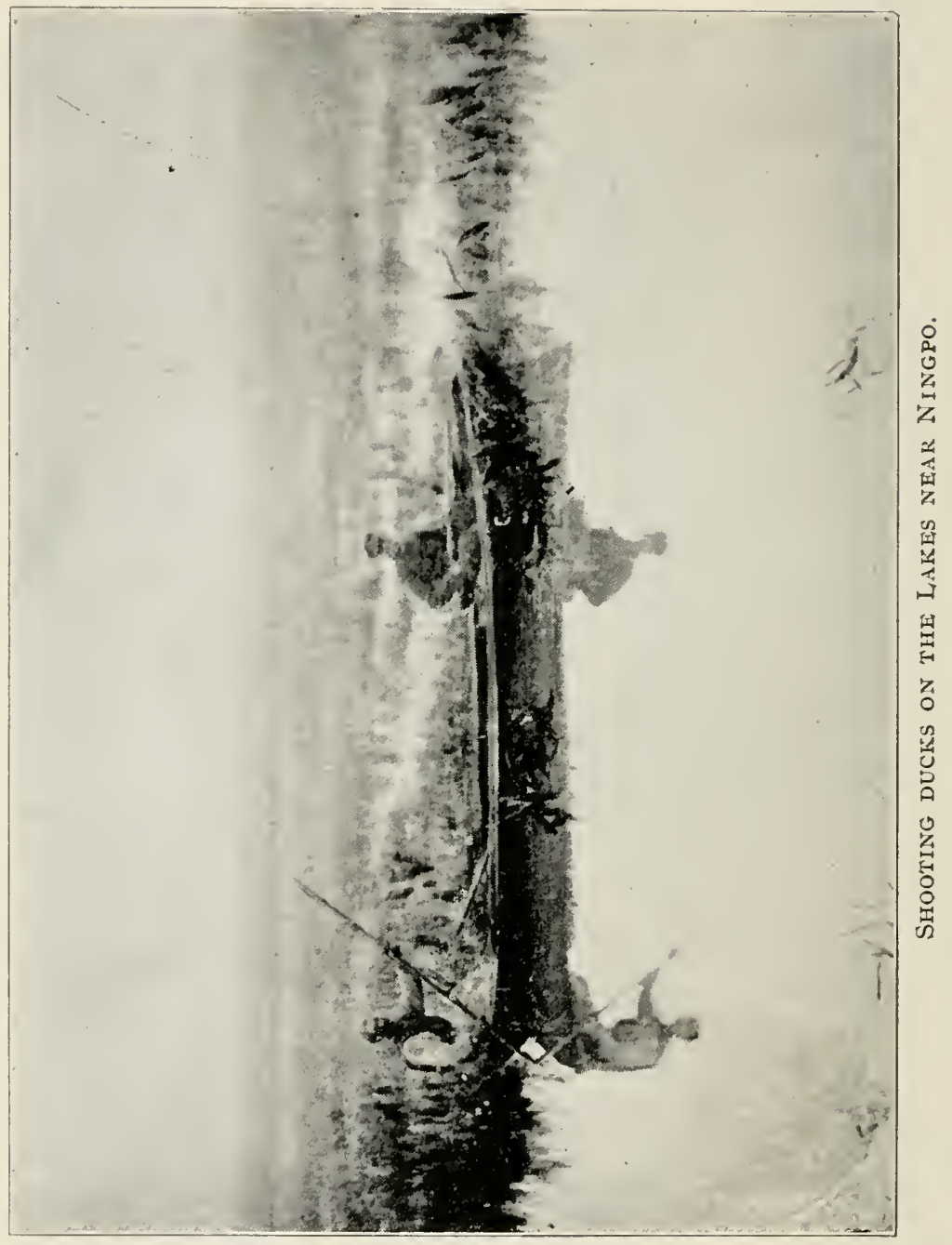


pole about eight feet long and pushes it along so as to make as little noise as possible while the shooter is firmly seated near the bow, and if the season is fairly favorable a bag of 20 or 30 mallards should be made for a morning or afternoon shoot. Decoys are not used; as the boat is made to move through the grass the ducks fly up from their feeding places, and usually not more than 30 or 40 yards, giving the shooter the best chances a sportsman could wish for. The ducks cannot as a rule be seen while feeding, and if they could should not be fired at while in the water. I have seen as many as 50 large mallards rise from the water and fly slowly over the tall grass and not more than 30 yards from my boat. It is then that the shooter ought to get in a good right and left, and if he missed should be put on short rations. I have never seen a canvass-back duck in any of the waters of China, but in addition to the mallard, the wigeon, the pintail, and the teal can be found in the greatest abundance. On the lakes also the wigeon and teal can be found in large flocks and large bags of these ducks are often made on a favorable day. About five years ago flocks of 
geese would come in from the sea late in the afternoon to roost in the lakes, but for the past season or so there have been scarcely any geese seen in the lakes, and this may be owing to the increased ninmber of fishermen who have recently been visiting there for the purpose of cormorant fishing. I have seen as many as a dozen small boats, each boat with ro or 15 cormorants, moving over the lakes from sumrise to sunset. I have also seen large flocks of ducks and geese hovering in the air above its waters, and finally flying away from the noise made by these cormorant fishers. It is impossible to feel in good humour when such things are going on in full view of the shooter.

I have been on the lakes when flight shooting was very good, but it only lasted for a short time when the ducks were flying in from the seacoast to roost, or early in the morning when they were leaving to feed on the shores of the seas wlich are not far from the lakes. If the shooter knows the favorite roosting places he has only to conceal his boat in the tall grass about an hour before sinset and cover the bottom with grass and wear a 
suit of clothes as near its color as possible. In such a cover he will probably bag ro or I 5 to add to the number shot in the earlier part of the day.

Since I have been in China I visit the lakes at least once during each season. I love to go there, because the bright waters and beantiful scenery seen to shut one ont from the noise of the great outer world and is so restful to look 11pon. It is true that shooting there is not on any grand scale, but it is sufficient for genuine amusement, and when the shooter tires of shooting wildfowl he can look for plieasants on the hillsides. If he has been thoughtful and brought his bird dog he should bag a couple of brace of strong 1110untain pheasants on his way to his houseboat. The pheasants I have shot in mountainous places are larger and stronger than those found on the plains. They are quicker in flight and to bring them down requires a steady nerve and clear eye.

In February I906, I was shooting on the lakes in conpany with a friend. The ducks were scarce and neither of ns were in a pleasant linmor when we returned to the houseboat one evening with scarcely enough 
game to gratify our appetites. I was suffering from a neuralgic pain in the face, and on retiring for the night I remarked to my friend that he could have the whole of the lakes to himself the next day as I would remain aboard the houseboat and not expose myself to the cold wind. Early next morning he equipped himself and I said goodbye and wished him better luck.

About 8 o'clock my Chinese servant came to my bunk and said the sun was shining brightly and he thought I would feel better by taking some out-door exercise. I dressed, drank a cup of coffee, and took my light I2 bore gun, loaded with No. 5 shot, and walked towards the dikes which hold back the waters of the lakes and prevent them from overflowing the little fields of the Chinese farmers. The particular dike I was walking towards connected two mountain ranges and was quite high and nearly half a mile in length. I had just reached it and was looking across the lake when my servant boy, who was walking behind, shouted out at the top of his voice, in Chinese, the name of the animal to which he wished to direct my attention. I knew that something 
unusual was going on, and as I turned to see what it was I saw a large wolf on top of the dike and running directly towards ine. The animal did not see me until it was within a few yards of where I stood, and then it increased its speed and, with a vicious growl, attenpted to jump pass ine, but when it touched the ground it fell stone dead. I do not know whether I hit it when I fired the first barrel, but I took no risk and the second quickly followed the first. In the meantime the boy was near me with a heavier $\mathrm{r} 2$ bore, used for duck shooting, and I heard him shout out again the same Chinese sound, and as I looked up there was another wolf, larger than the first, coming towards me from the same direction. I could see that the wolf I had shot was a female and the one coming towards me was the male. I exchanged guns and awaited his coming; he was a daring fellow and approached, plainly slowing his teeth, but I knew he could not escape. He made a similar jump, but on the opposite side of the dike from where his mate lay dead, and when he touched the ground he rolled over also stone dead. Not more than half a ininute was consumed in killing the two 
wolves and both lay dead on the ground not more than ten yards apart. I did not have any scales convenient and can only approximate the weight of the male, which my friend and I guessed as from the tip end of the tail to the nose the male measured $62 \mathrm{x} / 2$ inches, and the skin across the body measured 25 inches. The color was of light brown, but of a darker shade along the middle of the back.

As soon as it became known that two wolves had been shot a great many natives came to the houseboat to see them, and there was much rejoicing that two of the enemy of their flocks of sheep and goats had been killed. Of course a wolf should be shot in any condition, but I became somewhat sympatletic when I observed what appeared to be the true condition of the female. The day being rather warm I decided to have the entrails taken ont so as to preserve the hides the best I could, and when the female was cut open there rolled out half of a young goat which she had caught and eaten probably not more than a few hours before she was shot. When the natives saw that the wolves had been shot so soon after the 
killing and eating of the little goat their expression of gladness was intense at the just retribution. They walked around the carcasses again and again as if saying, "Yon remorseless tyrants of onr meadows, your nights of pillage are ended."

I do not know the moment the neuralgic pain left me, but I did not feel it again after I saw the first wolf. The male wolf looked as if there might be some fight in him. He must have heard the two barrels fired into the body of his comrade and seen her outstretched on the ground, and still he did not change his conrse, but seemed intent 11pon facing me. Somehow I was perfectly calin and collected, and with a Greener gun that had often proved trustworthy I felt as if my aim would be sure.

After the wolves had been put on board of the houseboat, I was feeling so much better I got aboard a canoe and had the boatman to push it to one of the islands in the lakes where I thought I might find a pheasant or a woodcock. Almost immediately after going ashore nuy dog put up a large cock pheasant which I bagged with the first barrel. I then looked up the lakes and saw my friend returuing from his 
morning shoot, and I pushed out to meet him. He had shot a hen-pheasant and one or two ducks and felt the need of a cup of strong coffee. I told him that I had shot two large animals but would not name them which excited his curiosity, and he proposed that we return to the houseboat and rest until the hour for afternoon shooting.

One of my most pleasant trips to the lakes was in company with another friend. Eäch of us owned a new 8 bore Greener gun and was anxious to put it to the test. We left Shanghai at 4 p.m. On one of the regular nail steamers, but did not reach the lakes until about 2 p.m. the following day. We had our houseboat pulled over into the lakes and had not yulohed far towards the lower end when we saw that the water in that direction was almost covered with geese and ducks. The 8 bores were at once taken out of the cases, cleaned of oil, and each had his small boat ready for the evening sloot. I was the first to fire and with a right and left brought down two large geese. As my friend had never stalked wild geese, he did not get any the first afternoon, but on the second he made a 
good bag of geese and ducks. The weather was favorable and we had been fortunate in arriving at the lakes at the proper time. Our bag during the two full days we shot counted r2o large ducks and 30 geese. It was the largest bag ever made by any shooter on the lakes witlin so short a time. It was larger than any I had made previously or since, and a pleasing feature was that the count to each gun was practically the same.

Within the past three or four years the foreign population of Ningpo has materially increased and there are many more shooters on the lakes than in former years, but the lovely scenery and clear waters are still inviting as a place for a few days of recreation.

The city of Ningpo has a population of 260,000 , and is one of the five ports opened to foreign trade by the Nanking treaty of r842. It is built in a plain and, as stated, on the left bank of the Yang-kiang river about fifteen miles from the sea. The plain in which the city is built is fertile and produces good crops of rice and wheat. The principal imports are kerosene oil, cotton piece goods, matches, sugar, coal, opium, 
tin, iron, soap and candles. The exports are rush hats, matting, paper fans and umbrellas, green tea, carpets, raw cotton and groundnut oil. Ice preserved fish is a considerable article of commerce. A few years ago the Ningpo plain was excellent shooting ground for pheasants, and the small ponds in the fields were favorite places of wild ducks, but now the game is not so plentiful, as the foreign population of the port in recent years has materially increased and the breechloader has proved as destructive there as it has elsewhere in China. 


\section{CHINESE SPOR'TSMAN}

\section{AND WEAPONS.}




\section{CHAP'TER VIII.}

CHINESE SPORTSMAN AND WEAPONS.

The foreign shooter who is a stranger to the shores of China will naturally inquire if the Chinese are fond of the sport and will wish to know something about the pattern of the gun they use for sporting purposes. The illustrations will give a more accurate idea of the native sportsman and his weapons than any written description, but it is hoped that by the aid of both to leave a fairly correct impression.

The Chinese have always been fond of hunting and shooting. In the early centuries the emperors, the princes, and the nobles furnished their proportion of sportsmen and the enjoyable recreation was participated in by the ruler and the ruled with zeal and perseverance. At stated periods of the year, when the crops had been gathered and the farmers were at leisure to assist in "beating" up the game, the sport began. According to their respective ranks the sportsmen would meet at some appointed place either in the valley or on the plain; the higher in rank travelling in chariots, 
others on horseback and others on foot. When thus assembled the peasantry would begin to drive the aninuals ont of their liding places towards the hunters and then the real sport would commence. It appears that each hunting party had its distinct preserve and was not allowed to go beyond the limits of it. The weapons chiefly used in the early days were bows and arrows, spears and slings. The arrow heads were made of bronze which at that date was a very valuable metal, and with his natural keenuess for profit the Chinese follower of the sportsman made it a profitable business to pick up arrows which missed their mark and returning them for the reward usually given for such finds. It was customary to divide the meat of the animals slain among the people who were assisting the sportsmen by driving ont the game, while the skins and horns were retained as trophies of the hurit.

When the princes and nobles neglected to organize the customary hunting expeditions they were considered by the people as indolent and lazy. As the wild animals were destructive to the crops of the farmers this class of the population 
especially looked to their officials to protect them from all depredations, and the neglect to do so has been known to provoke the most serious discontents. It was an argument that the people did not have any use for weapons because of the organized lunts by the officials, but later on when such hunts became less frequent the people gradually began to procirre weapons to defend their property. It is related that the great Chinese Sage, Confucius, who lived in the third century of the Christian Era, practiced archery on foot, if not on horseback or from his travelling chariot. He declared that it was the duty of the superior man to learn the use of weapons in order to be able to defend himself, his family, and his property against man or beast, and to be better qualified to assist the state against its enemies. But here at least is one advice and exan1ple of Confucius which has not been very well observed by succeeding generations of his comntrymen. His advice with reference to the women of China resulted in the enslavement of their sex to the baser feelings of man, and his male countrymen have strictly followed it, but on the theatre of true manhood they have 
been powerless to defend China from aggression and insult, and all because of their want of patriotism.

During the thirteenth century of our era the emperors of the Yuan dynasty, being Mongolians, were hardy sportsmen as well as warriors, and were accustomed to organize hunting expeditions on a large scale and took an active part, themselves, in the chase. These emperors established immense parks and preserves for wild animals, including many varieties of beasts and birds, where they and the nobles went every winter to hunt them. Aside from the healthy exercise of the mind and body, resulting from the active participation in the sport, it taught the practical use of weapons, and they also became inured to the hardslips of long journeys, camp life and the use of the saddle.

The earliest emperors of the present dynasty ('Ta-cling) were also ardent sportsmen and fond of other field exercise. These emperors were Manchurians, and followed the examples of their Mongolian predecessors by organizing hunting expeditions, establishing Imperial Parks and game preserves beyond the Great Wall. During 



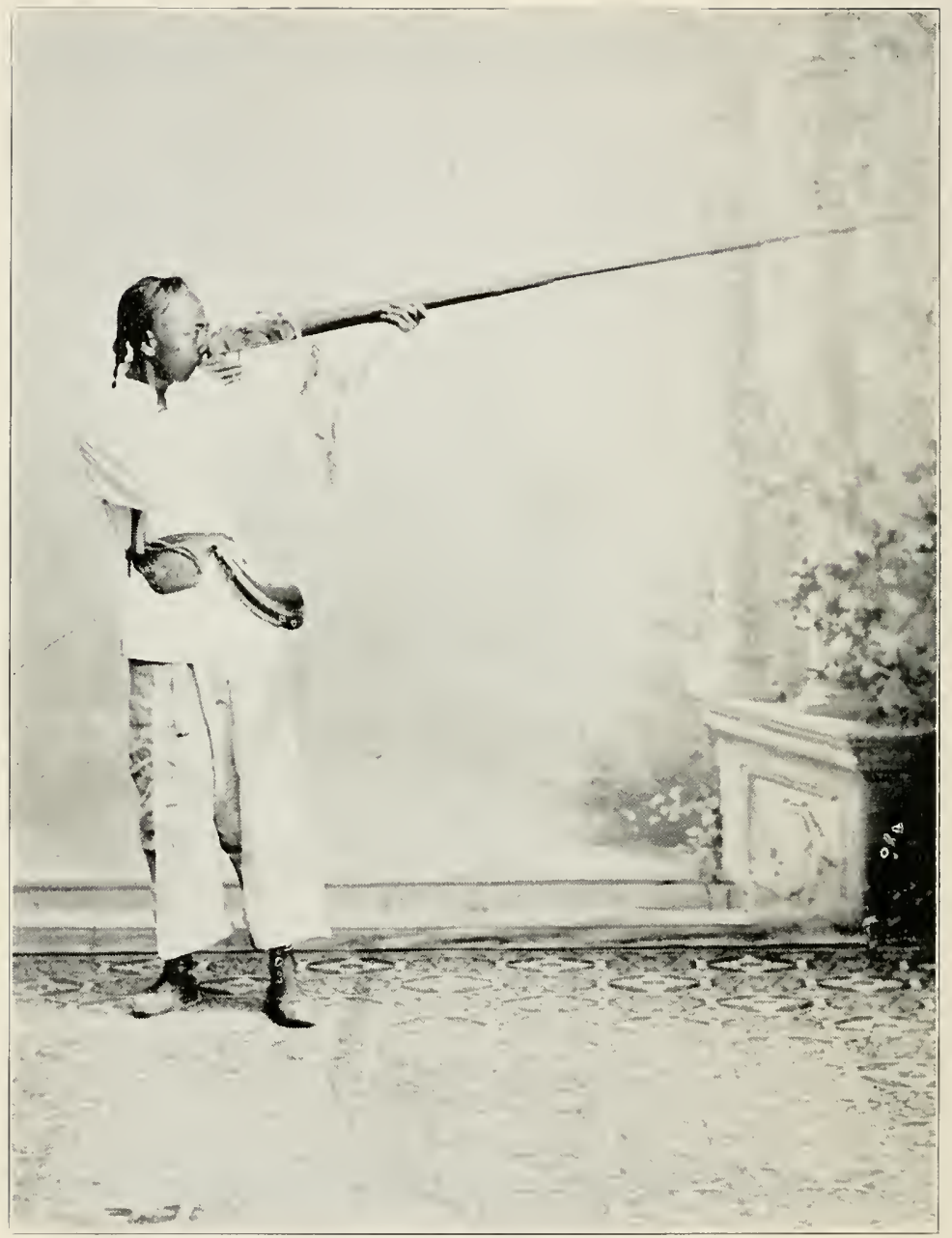

CHINESE SPORTSIIAN. 
each winter season immense quantities of game were killed, which included animals of the most ferocious nature,-such as the royal tiger and the imperial bear. Thus it happened that the Emperor Chien-lung lost his life, after slaying an enormous bear, on one of these hunting expeditions.

Those were the days of sportsmen who were really fond of sport, and the days, too, when China and the Chinese were in the foremost rank of art, science and literature, and when the civilization of China was abreast of the times. But since those days sport and sportsmen have greatly declined in the good estimation of Chinese. The study of science, art and literature has been much neglected, or not advanced as it should have been to have inaintained the supremacy of China over eastern countries, as when sport and sportsmen were held in esteem. No people in the world enjoy sport as keenly as the English, and this has been true since that people became known to history. It is also true that no people has accomplished more in art, science, literature and government, or ever fashioned a more perfect system of laws than the Englisli speaking race. 
The Chinese sportsman of the present day is, in every essential equipment, as far behind the western sportsman as China is behind western nations in civilization. $\mathrm{He}$ shoots with an old pattern muzzle loading matchlock gun which he calls Niao-chiang. The barrels may be from four to six feet long, sometimes longer, and is mounted on a stock something like an old fashioned horse pistol. The gum barrels are usually round, except in Kweicliow where the barrel is generally octagon in shape and from five to seven feet long. All occupations in China are classified, and the son invariably follows the occupation of his father; the sportsman or shooter is, therefore, a professional, especially in western China where many of them are pious men. There they worship Loa Tien Yah, the old heavenly sire, and beseech him to preserve them from all harm and grant them success in their perilous undertakings among the beasts of the forest. The Chinese soldiers, who are stationed as military colonists in Miaoland, or their offspring, sons of Miao maids, engage in sport as a pastime, and some of them are expert in the use of their weapons. They hunt big game, not alone 
for the sport, but for the reward paid by the officials for the capture or killing of a beast of prey. There is a profit also derived from the sale of the skins and horns of wild animals. The means employed to capture big game is not sportsmanlike according to the modern definition. Traps and snares of many conceivable designs are used, one of which is a cross-bow loaded with poison arrows which are discharged into the body of the animal that happens to touch the simple trigger lying across the path to some watering place. The poison used is a secret but it is believed by Chinese to be derived from snakes, lizards, toads and centipedes combined with some metal substance like phosphorous. It is deadly in its effect to man or beast. Another snare, used by the Miao sportsman, is made by bending stout bamboos or young pine-trees and tying them down to other trees near the ground with a running noose into which the animal gets caught by the reck and, in struggling to get away, detaches the trigger, when the tree springs upright and thereby hangs and strangles the animal to death, a method that has the advantage of leaving the flesh free from poisou. 
Pits are sometinles dug, with sloping sides broader at bottom than top, and which are covered with brushwood overlaid with earth and grass, and over which an nnsuspecting animal will attempt to walk and consequently fall into the pit, there to remain until his captor comes, as owing to the inward slope of the pit the animal cannot get ont. In the Yang-tze Valley, where there are a great many wild fowl, the rative sportsman provides himself with a small punt on the forepart of which he mounts a heavy matchlock musket, which is known as the gingal, something like the ancient blunderbusses or wall pieces used in the defense of ancient castles.

For ammunition the sportsman uses a common grade of black powder and cast iron shot, and is not particular as to the quantity of powder or shot he wads into his gun as long as he believes that it will not be damaged by the discharge. When the gun is loaded the shooter disguises himself and punt as a floating busli by tying branches of trees and plants over all in such a manner as the wild fowl may not suspect and fly away. He then embarks on his frail punt with a paddle, a pole and 



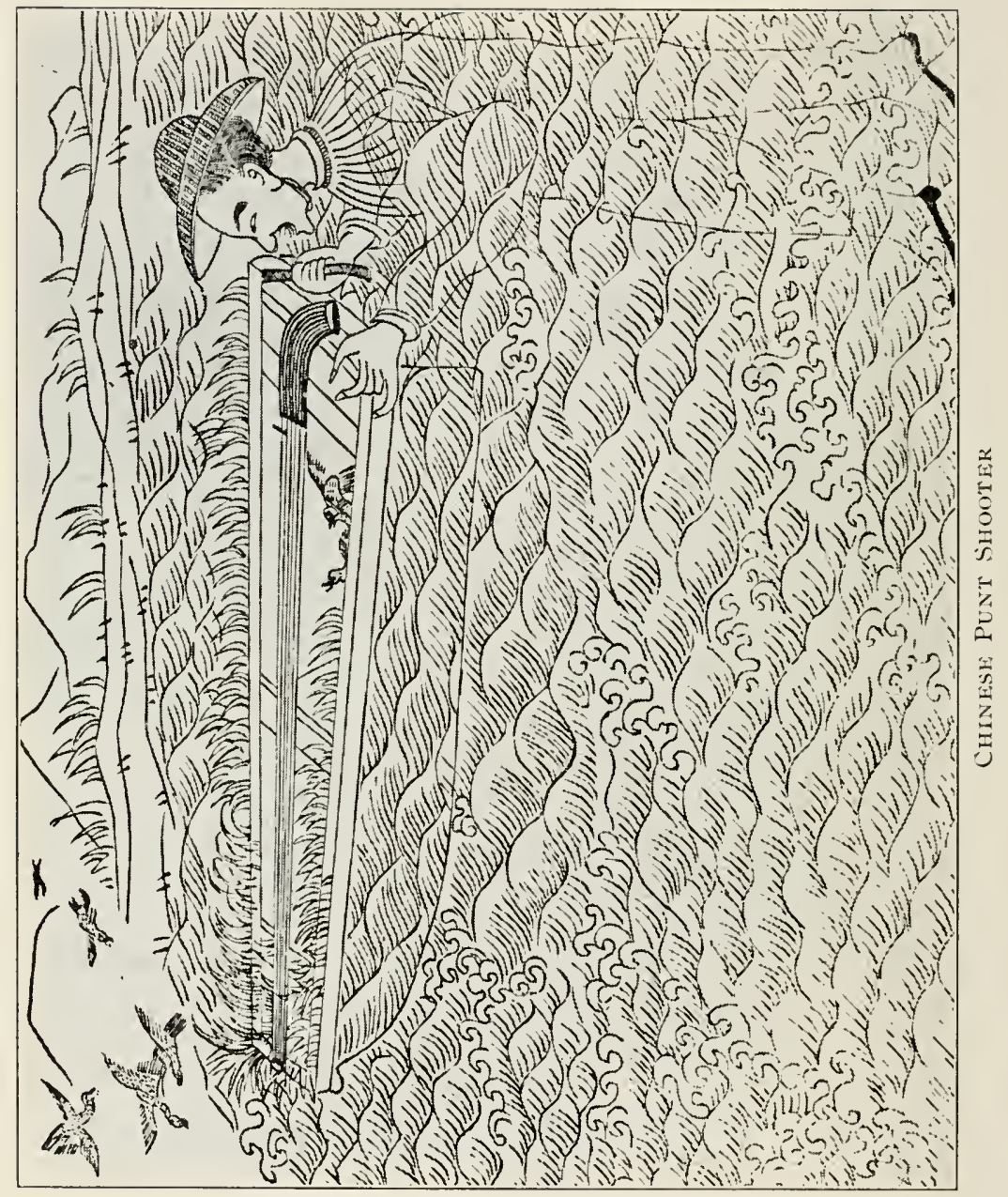


a landing net, and gently propels his boat into the lake, some distance from the shore, where the wild fowl are expected to come. After thus being stationed he conceals himself and keeps a lookont for the expected game, and when all is ready the gingal is fired off with a slow match, and the dead ducks or geese are picked up with the landing net and put into the after part of the punt. The kill is sometimes quite large, but the Chinese are not ambitious to make big bags, and thus at least they have one idea of true sportsmanship. In Kwei-chow there are many of the sportsmen who will not shoot at a bird while it is on the ground. They shoot their gane on the wing, an act not so easy to accomplish with a matchlock as it is with a modern breech loader.

The Miaotzu sportsman generally makes or helps to make such a gun as he wishes to use, not only the lock, stock and barrel, but his ammunition as well. He first provides the necessary quantity of good scrap iron and charcoal, builds a forge near his house and erects a light shed of mats or branches over it, and then invites some famous swith of the district to come and 
forge the barrels for the intended gun. This is done by welding the scrap iron into several bars, each about one inch broad and a quarter of an inch thick. Each of these bars is then coiled spirally on a small mandrie and afterwards welded into as many cylinders or tubes, each about one foot long. These tubes are joined together by welding end to end and thus mited form the barrel of the gun, which is a twist barrel of good material and manufacture. The barrel is now fastened by wedging into a log of timber, the muzzle end downwards and bored out by hand with square steel rimmers. These rimmers are made of different lengths and dianneters and have a wood cross bar at the top which is turned slowly and steadily until the whole length of the gun barrel has been bored ont into a uniform and satisfactory manner. The work may occupy months of the shooter's spare time, but when finished the long barrel has been bored true and straight and smooth, and he has the satisfaction of knowing that lis gun was built directly under his own supervision and materially with his own hands. The breech is closed by welding a prepared pling of iron therein. 



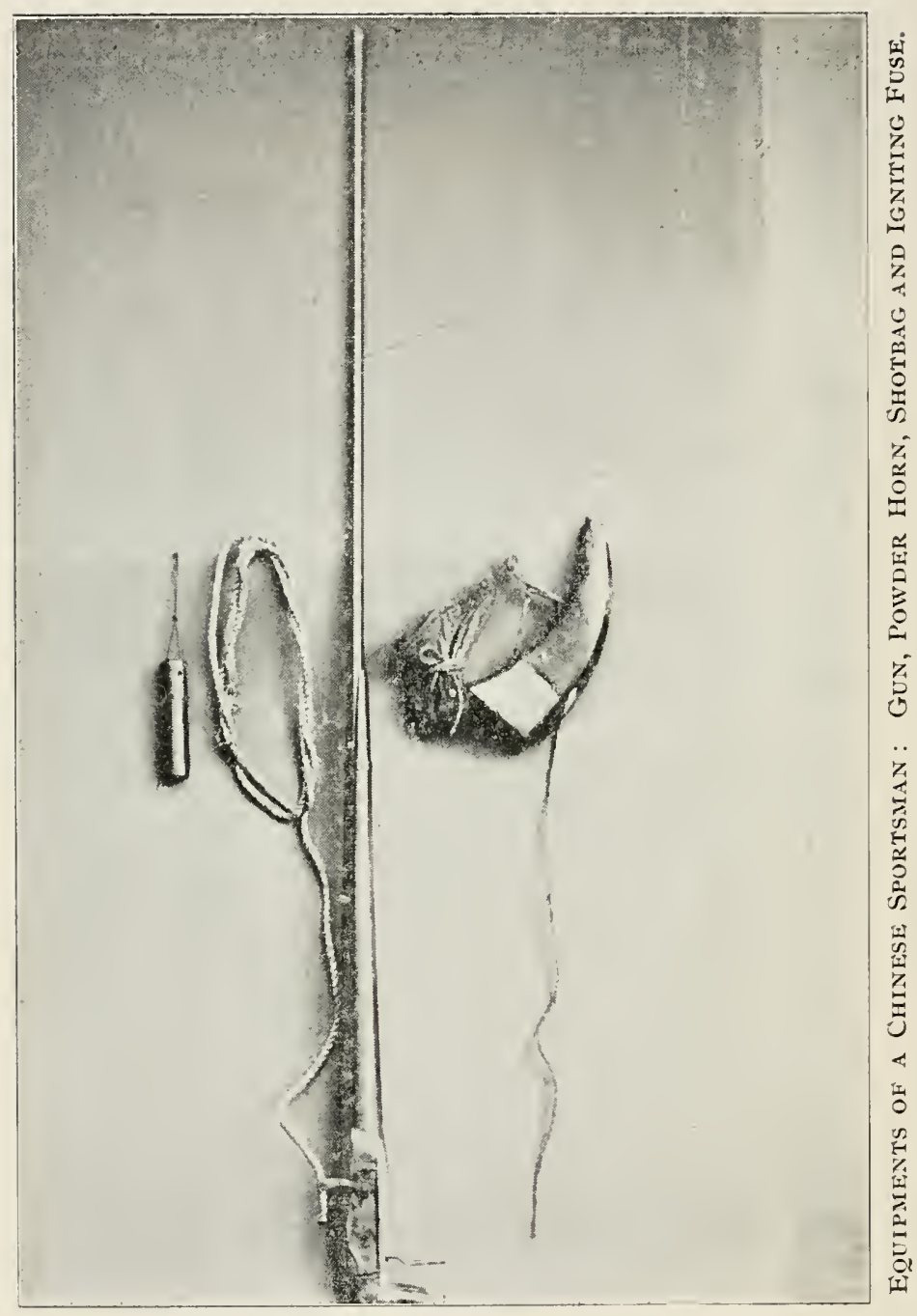


The bend is carefully filed on the outside and the vent spliced in a suitable place. The priming pan is added in such a manner as to meet the special requirements of the shooter, whether right-handed or lefthanded. The barrel is mounted on a pistol stock, fitted with a spring cock and trigger and fastened on the outside of the stock near the breech, the barrel being fastened to the stock by moveable thin silver bands, each from a half to one inch in width. The barrel is then removed from the stock, made red hot over a slow fire and rubbed over with some wild grass which, on touching the barrel, turns it a fine dark blue. After this process the barrel is again mounted on its simple stock and presents rather a handsome appearance.

Now that the shooter has his new gun ready for use he loads it with home made powder and shot and fires it by a slow match ingenously applied to the priming powder by the beak of the cock when the trigger is pulled. As stated, the ammunition as well as the gun, and as well as the implements for carrying the anmunition, are all of home mannfacture, and usually made by the shooter. 'The powder is made almost 
in the same manner and with similar ingredients as in western nations, but with about five per cent more of saltpeter and with a little less sulphur and charcoal. It is inperfectly granulated and is slow burning. The priming powder is made by moistening a quantity of the ordinary charging powder with alcohol and reworking it, drying and pulverizing it very finely. The powder horn is also fashioned by the hand of the shooter. He gets the horn of a water-buffalo, saws off the small end, and with the remainder he fashions a horn for his powder holding from a half to one pound. For general shooting the charge of powder is measured in a tube and somewhat heavier than the charge used for an Enfield rifle. The bullets are made of fine lead cast in banboo tubes about six inches long and a little larger in diameter than the bore of the gun. The lead is then rolled between two boards until it is reduced to proper diameter. It is then cut in lengths of four diameters each for bullets and one diameter for slugs, so each bullet is equal to four slugs. These leaden bolts or bullets and slugs carry farther than spherical bullets or slugs because, being the diameter of the 
bore and slugs being superimposed, the full force of the powder acts on the flat base of bullet or slug and drives it forward, the speed being accelerated by the slow burning large charge of powder in the long barrel smooth bore or cylinder gun. Loading is, however, very slow work. The charge of powder is rammed home into the powder chamber which is slightly larger in diameter than the nuzzle of the gun. For ramming purposes an iron ramrod is used, a fraction smaller than the bore of the gun. There is no wad of any kind between the powder and the bullets, but on top of the latter a bit of paper or grass is rammed to prevent them from falling out. When the priming powder lias been poured into the pan near the vent it is pressed down with the thumb nail, in order that it may not fall off when the shooter is moving about or blown off by the wind. The slow match is made of coarse hemp rope about half an inch in diameter, steeped in a strong solution of saltpeter and dried in the sun. This rope is an average of ten feet long and made into a small coil, which the shooter carries around his right or left wrist as most convenient to him when firing his gun. The end of the 
rope is lighted by flint and steel and a vegetable punk. When about to fire the shooter blows on the burning match, fixes it suitably in the open beak and takes his aim at the object he wishes to shoot. The pistol like stock of the gun usually rests against the hip of the shooter when firing, and he fixes both eyes on the object, although he appears not to be taking any aim at all. It would seem that the principle of shooting with both eyes open and fixed on the game has been long known to the Chinese and other Asiatics who have made use of the gun either when engaged in sport or war. The short pistol like stock clearly indicates that it was not intended to shoot from the shoulder, and that the most skilfull of these marksmen recognized the advantages of using both eyes when aiming their guns.

There is no character in the sporting field as unique and original as a Chinese sportsman. Although his dress and other equipunents appear wanting in every essential to ensure success and comfort, nevertheless, the result of a day's shooting will sometimes suggest whether the breech loader is really more effective than the 
matchlock. During the season of I904, I was shooting on the Yangtze river and on one occasion anchored my houseboat near the bank on which stood a small straw thatched hut. Early the following morning there came on board a young Chinaman of splendid physique and at once began an animated conversation with my Chinese boy servant. As the latter spoke English I soon learned that my boat was anchored near the hunting ground of my visitor, but he extended a cordial in ritation of welcome because, he said, that he was ont of ammunition and hoped that I would give him a few loads for his gun. Appreciating the somewhat selfish element in his welcome, I made the condition that I would comply with his request if he would pilot me to the best shooting ground, and to which he readily consented. I opened several cartridges and gave him the contents and soon we were on our way to the happy lunting fields. His gun was of the matchlock pattern, with an iron barrel about five feet long, and weighing as much as sixteen pounds. The stock was made of wood and of the shape of a carpenter's plane. At the breech the barrel was 
provided with a small aperture into which a bit of iron plate was inserted to serve the purpose of a pan,the ignition being affected by means of a smouldering match rope. The bore at the muzzle was smaller than at the breech, evidencing that the Chinese knew the advantage of shooting with a choke bore gun long before the idea was developed by western gun-makers. The powder which my new acquaintance had been accustomed to use was of home manufacture, and already referred to, but, to be more specific, it is usual to mix three catties of ground charcoal, three catties of saltpetre, ten of sulphur, and after putting it all in a pan, and pouring over it a jar of Kaoliang spirits, the pan would be placed over a slow charcoal fire and the mixture well stirred with a stick until it becane of the consistence of paste; it would then be laid ont on paper in the sun to dry. The quality of the powder thus made is not good, but this can be materially improved by the quality of the ingredients, and when a finer quality is wanted rattan cliarcoal is used. However the powder manufactured in Clinina for sporting purposes is black and dirty and necessitates the constant washing 
out of the gun barrel, but the barrels are seldom cleaned until the end of the season, and sometimes never cleaned.

The dress of thesportsman is as primitive as his gun. He 11sually wears a pair of straw sandals for boots and his clothing is made of a very inferior grade of cloth. I could not see that the sandals were any protection against the scrub oaks and briars which grew on the hillsides or the swordlike grass of the plains, but there was a lightness and noiselessness in tlie step which showed that the lieavy boot of the foreigner would not serve him so well. The clothing was no protection either. It seemed that one so thinly clad would soon get chilled through by the cold winds that sweep the low lying plains between the hills and shores of the river.

It is seldom that the native sportsman shoots over a dog. Occasionally a sportsman will be accompanied with beaters, but oftener his noiseless step and quick eye find the game and bag it. A friend informed me that on one occasion, at the close of a cold December day, he was walking near a lake when he saw a Chinaman who was beckoning to him. As he 
approached he was asked not to shoot the ducks which were in the lake, as a Chinese sportsman was in the water; awaiting to see what would happen, he saw the sportsman, nearing the shore, wearing a large bamboo collar. He was carrying a basket in which were a few wild and three tame ducks secured together by a string. His dress was of goatskin witl the wool inside; the stockings were stitclied to his clothing, and thus accoutred he immersed his body, using the cangue as a float. On his hat were placed bunches of grass, and on the cangue two or three decoy ducks. He would thus approach the wildfowl and, when near enough, dexterously catch the unsuspecting duck by the leg and drag it under the water. My friend states that he watched the sportsinan lintil he had filled his basket with wild ducks.

Reference has been made to some of the emperors of China who were fond of sport. Fortunately there is an account in Marco Polo's writings of a hunting expedition of the Emperor Kuhblai Khan, and as the description may prove interesting I reproduce it in the words of Polo who writes as an eye witness. The Venetian writes as follows: 


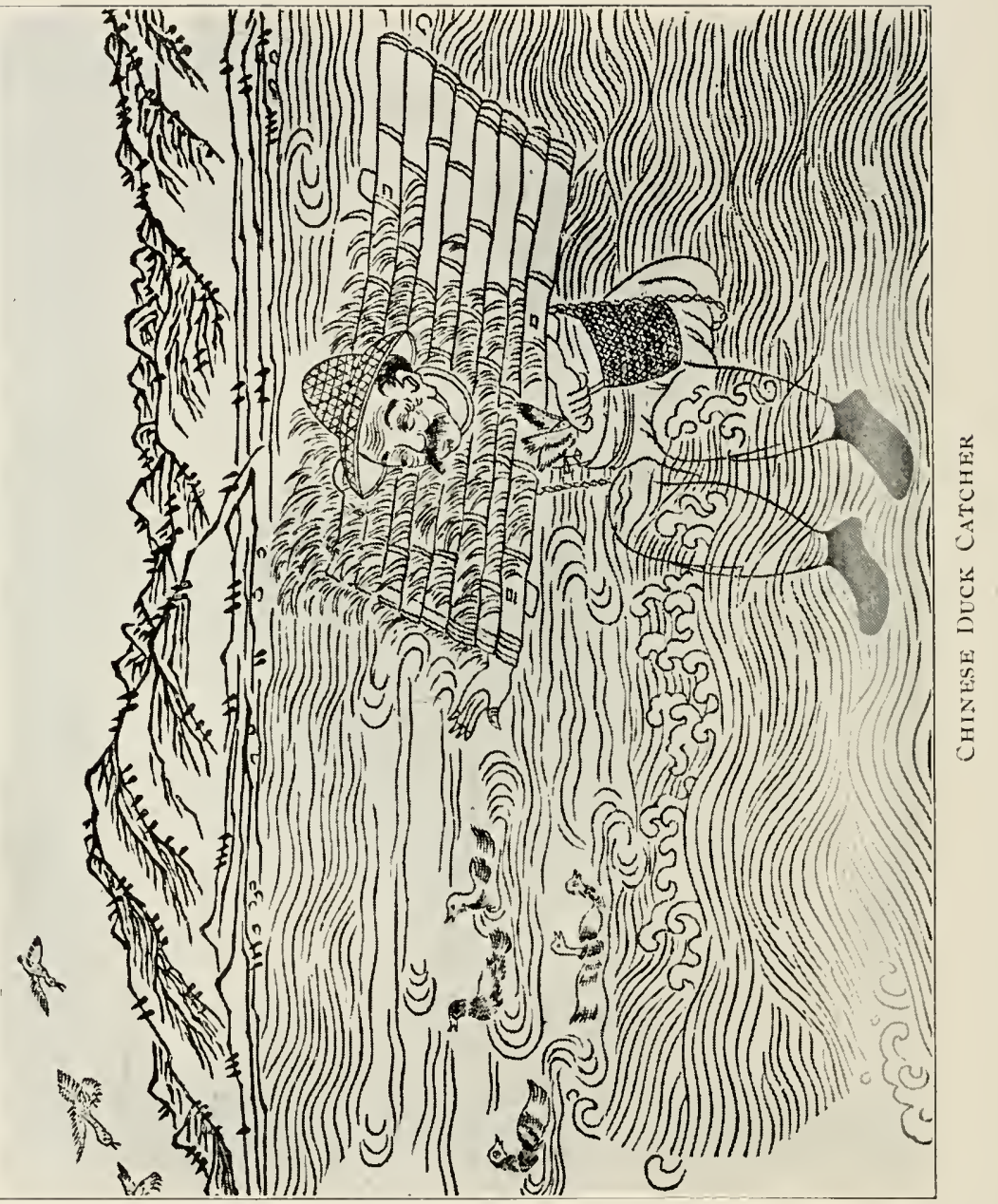


"After he has stopped at his capital city (Peking) those three months that I mentioned, to wit, December, January, February, he starts off the first day of March, and travels sonthward towards the Ocean Sea, a journey of two days. He takes with him full Io,ooo falconers, and some 500 gerfalcons besides peregrines, sakers, and other hawks in great numbers, and goshawks also to fly at the water-fowl. But do not suppose that he keeps all these together by liim; they are distributed about, hither and thither, one liundred together, or two hundred at the utmost, as he thinks proper. But they are always fowling as they advance, and the most part of the quarry taken is carried to the einperor. And let me tell you when he goes thus a-fowling with his gerfaicons and other hawks he is attended by full ro,ooo men who are disposed in couples, and these are called Toscaol, which is as much as to say, "Watchers." And the name describes their business. They are posted from spot to spot, always in couples, and thus they cover a great deal of ground. Every man of them is provided with a whistle and hood, so as to be able to call in a hawk and hold it in hand. And when 
the emperor makes a cast there is 110 need that he follow it up, for those men I speak of keep so good a look out that they never lose sight of the birds, and if these have need of help they are ready to render it.

"All the emperor's hawks, and those of the barous as well have a little label attached to the leg to mark them, on which is written the names of the owner and the keep of the bird. And in this way the hawk, when caught, is at once identified and handed over to its owner. But if not, the bird is carried to a certain baron, who is styled the Bularguchi, which is as much as to say "The Keeper of Lost Property." And I tell you that whatever may be found without a known owner, whether it be a horse, or a sword, or a hawk, or what not, it is carried to that baron straightway, and he takes charge of it. And if the finder neglects to carry his trover to the baron, the latter punishes him. Likewise the loser of any article goes to the baron, and if the thing be in his hands it is immediately given up to the owner. Moreover, the said baron always pitches on the highest spot of the camp, with his banner displayed, in order that those who have lost or found anything 
may have no difficulty in finding their way to him. Tluns nothing can be lost but it shall be incontinently found and restored.

"And so the Emperor follows this road that I have mentioned, leading along in the vicinity of the Ocean Sea (which is witlin two days' jonrney of lis capital city, Cambulae), and as he goes there is many a fine sight to be seen, and plenty of the very best entertainment in hawking; in fact there is no sport in the world to equal it.

"The emperor hinself is carried upon four elephants in a fine chamber made of timber, lined inside with plates of beaten gold, and outside with lions' skins (for he always travels in this way on his fowling expeditions, because he is tronbled with gont). He always keeps beside him a dozen of his choicest gerfalcons, and is attended by several of his barons, who ride on horseback alongside. And sometines, as they may be going along, and the emperor from his chamber is holding discourse with the barons, one of the latter shall exclaim: "Sire! Look ont for cranes." Then the emperor instantly has the top of his chamber thrown open, and having marked the cranes he casts one of his gerfalcons, 
whichever he pleases, and often the quarry is struck within his view, so that he has the most exquisite sport and diversion, there as he sits in his chamber or lies on his bed, and all the barons with him get the enjoyment of it likewise. So it is not without reason I tell you that I do not believe there ever existed in the world or ever will exist, a man with such sport and enjoyment as he has, or with such rare opportunities.

"And when he has travelled till he reaclies a place called Cachar Modun, there he finds his tents pitched, with the tents of his sons, and his barons, and those of his ladies and theirs, so that there shall be full Io,ooo tents in all, and all fine and rich ones. And I will tell you how his own quarters are disposed. The tent in which he holds his conts is large enough to give cover easily to a thousand souls. It is pitched with its doors to the south, and the barons, and knights remain in waiting in it, whilst the lord abides in another close to it on the west side. When he wishes to speak with any one he causes the person to be summoned to that other tent. Immediately behind the great tent there is a 
fine large chamber where the lord sleeps, and there are also many other tents and chambers, but they are not in contact with the great tent as these are. The two audience-tents and the sleeping-chanber are constructed in this way. Each of the audience tents has three poles, which are of spice-wood, and are most artfully covered with lions' skins, striped with black and white and red, so that they do not suffer from any weather. All three apartments are also covered outside with sinilar skins of striped lions, a substance that lasts forever. And inside they are all lined with ermine and sable, these two being the finest and inost costly furs in existence. For a robe of sable, large enough to line a mantle, is worth 2,000 bezants of gold, or I,OOO at least, and this kind of skin is called by the Tartars "The King of Furs." The beast itself is about the size of a marten. These two furs of which I speak are applied and inlaid so exquisitely that it is really sonething worth seeing. All the tent-ropes are of silk. And in short I may say that those tents, to wit, the two andience-halls and the sleeping chamber, are so costly that it is not every king could pay for them. 
"Round about these tents are others, also fine ones and beautifully pitched, in which are the emperor's ladies, and the ladies of the other princes and officers. And then there are the tents for the hawks and their keepers, so that altogether the number of tents there on the plain is something wonderful.

"To see the many people that are thronging to and fro on every side and every day there, you would take the camp for a good big city. For you must reck on the leeches, and the astrologers, and the falconers, and all the other attendants on so great a company, and add that everybody there has his whole fanily with him, for such is their custoll1.

"The lord remains encamped there until the spring, and all that time he does nothing but go hawking round about among the cranebrakes along the lakes and rivers that abound in that region, and across fine plains on which are plenty of cranes and swans, and all sorts of other fowl. The other gentry of the camp also are never done with hunting and hawking, and every day they bring home great store of venison and feathered game of all sorts. Indeed, 
without having witnessed it, you would never believe what quantities of game are taken, and what marvellous sport and diversion they all have whilst they are in camp there.

"There is another thing I should mention: to wit, that for twenty days' journey round the spot nobody is allowed, be he who he may, to keep hawks or hounds, though anywhere else whosoever list may keep them. And furthermore thronghont all the Emperor's territories, nobody however audacious dares to hunt any of these four animals, to wit, hare, stag, buck, and roe, from the month of March to the month of October. Anybody who should do so would rue it bitterly. But those people are so obedient to their lord's command, that even if a man were to find one of those animals asleep by the roadside he would not touch it for the world! And thus the game multiplies at such a rate that the whole country swarms with it, and the emperor gets as much as he could desire. Beyond the term I have mentioned, however, to wit, that from March to October, everybody may take these animals as he list. 
"After the emperor has tired in that place, enjoying his sport as I have related, from March to the middle of May, he moves with all his people, and returns straight to his capital city of Cambulae (which is also the capital of Cathay, as you have been told), but all the while continuing to take his diversion in hunting and hawking as he goes along."

There are some interesting notes by Yule on the above quotation from Marco Polo. The accuracy of the description on the route is doubted and difficult to reconcile with truth, but the direction of the excursion is armitted to be correct. As the crow flies, Peking, which was Kulbblai's capital, is about one lundred miles from the nearest point of the coast in a sontheast direction, and for such a camp, as Polo has described, to reach the point of destination at least five or six days would be consumed. Yule further thinks that the "Ocean Sea" referred to would be struck at Shan-haiknan, near the terminus of the Great Wall, and that the site of the standing hunting camp is to the north of that point. In I682 the Jesuit Verbiest accompanied the Emperor Kanglii in a tour in the same 
direction, and almost immediately after passing the Great Wall the emperor and his party seem to have travelled to the left for sport.

But the Emperor Kulblai was not the only oriental ruler whose hunting expeditions were of lavish proportions. The Emperor Kanghi was fond of sport, and imitated his predecessor in the splendor of his hunting equipments. It is recorded that Bajazet had 7,000 falconers and 6,000 dog keepers, whilst the Sultan Mohomed Inghlaka, India, in the generation of Polo, is said to have had ro,ooo falconers, and 3,000 other attendants as beaters. 

CUSTOMS. 



\section{CHAPTER IX}

CUS'TOMS.

If there be one custom which is general in China it is what the westerner would call the custonn of living in discomfort. Probably 110 people in the world can offer fewer comforts to a traveller from the west than the Chinese, and the shooter who leaves an open port with the expectation of finding accomodation in native houses will soon learn that he has wholly miscalculated. It sometimes happens that during a day's slioot one is overtaken by night when some distance from his houseboat, and it would be restful to stop at a native house in order to be on the shooting ground early the following morning, but such an idea had better not be entertained. However far the shooter may be from his louseboat when so overtaken it will be invariably necessary for him to return for refreshment and sleep or shoot the next day with unsteady nerves. It is therefore supposed that when the shooter gets aboard his houseboat and points her bow towards the interior he understands that he has left domestic and social conforts 
belind in so far as he has not provided himself with them.

There are public inns in China where the natives appear to find the comforts which satisfy them, but the experience of a night at a Chinese inn will leave the westerner with an impression never to be gotten rid of. As a rule the food is so prepared and of such a character that it is really uneatable, and unless the traveller has been thoughtful in providing both food and drink he will suffer much in consequence; and the sleeping arrangements at a Chinese inn are as repelling as the food on the table. Occasionally an egg may be bought, but the shooter must remember that the age of an egg adds greatly to its value and appreciation by the Chinese. The bedstead in an inn is known as the kang, which is a kind of platform, and when the weather is cold it is heated so as to keep the sleeper warm. This platform is built of brick and will measure in width more than two full size English bedsteads, and when necessary will accomodate several sleepers. The kang is about two feet high, the top being covered with large and thin red bricks presents a smootl surface. The interior is 
not solid, but is permeated by a tunnel or flue which begins at the side or end and after passing back and forth in its interior connects with a chimney on an opposite end or side. A short time before the platform is to be used for sleeping purposes, provided the weather is cold, a small quantity of dryfuel is set on fire in the accessible parts of the outer extremities of the flue, and the flame, hot smoke, and heated air passing through the flues warms the kang. The traveller then places his bedding on this hard and slightly heated platform and retires to rest at his convenience. The keeper of an inn is not always thonghtful as to who are made sleeping companions, and if the westemer is not careful in his preparations for a night's sleep he may awake to find himself wedged in between the most disagreeable characters for bedfellows.

And as a rule the liomes of the people are as uncomfortable as their inns. There are a few substantial brick houses, but the houses of the Chinese are nsually built of wood, or bamboo slats which are covered with mud, and are mostly one storey high, covered with earthen tiles burned in kilns, or with rice or wheat straw. The flooring 
of most houses among the poorer classes is made of a cement composed of clay, sand and lime, and is hard and smooth when properly prepared, or it is simply the earth pounded down. The wooden floors, even in the better class of houses, are very poor, uneven and unplaned. No carpets are used and seldom is matting spread upon the flooring. Oftentimes there is no ceiling overhead, the room extending to the roof. A large number of Chinese live in boats of various sizes, and in such boats children are born, brought up, marry and die. Even in the houses of wealthy families one seldom sees a glass window, the windows being of wood, though sometines they have a kind of a transparent shell arranged in rows. When the weather is cold the wooden windows are closed and the houses are then very dark inside. When light is needed the windows are partially opened, but this admits the cold as well as the liglit, and for purposes of ventilation such windows are insufficient. 'The houses, as a rule, have no fireplaces, furnaces and stoves as in western lands, and as the windows and doors appear never to be tightly fitted one can readily understand how uncoinfortable must be a 
Chinese house during cold weather. It is a custom, however, that when a Chinaman begins to feel the cold he will pnt on an additional suit of clothes, and when he feels the approach of warn weather he will begin to disrobe as the temperature becomes warmer.

But if the shooter could find an inn or private house that appeared comfortable inside the smell around either would very likely cause him to turn away. It is difficult to understand the keen appreciation the Chinese have for bad smells. However neat the onter appearance of a house may be the atmosphere about it is invariably filled with the most repelling scents. In the "Social Life of the Clinese" Doolittle has given a more detailed acconnt of the customs than any other writer, and makes a nearer approach to covering the entire subject, but after all his industry and research and the closest observation a partial view has been presented, and the subject, like the great country itself, is still exhaustless. In the "Chinese Characteristics" Smith has interested and instructed, but the information he gives relates mostly to one part of China, and 
could not be said to be more than generally accurate if closely studied in its application to other parts. When every province, city, town, village and neigliborliood has its own peculiar customs, and different from what prevails anywhere else, the impossibility of applying any general rule to the whole of the Empire is readily apparent. No one has yet seen every part of China and until that is done no one can write a book that will contain a complete account of the customs of the Chinese. If the shooter should feel an interest in the general and more important customs he can learn them by reading the books I have referred to. In the details Doolittle has successfully stood the test as the highest authority, but in the pleasures of style Smith is more entertaining.

But there are some minor customs which liave come under my observation at Shanghai and Soochow, and as such often prove the unerring index to the habits of thought and the social life of a people, I hope that I am not digressing too far by writing about them in this connection. At one period of the history of China Soochow was the educational center and still retains some of 
its former reputation, and Shanghai is today the commercial metropolis of the Chinese Empire. I have selected a few of the minor customs of these two cities to write of because, in the one city the classic thought of China has not opposed them, as in the other they have not become obsolete, although in daily contact with the spirit of modern commerce.

Most of the customs have a basis in the history of China, but in many cases the facts on which they are founded have been forgotten. Often diametrically opposite explanations are given of the same custom by those who possess exact knowledge as to its history, and thus do doubts increase as one inquires. It is, however, certain that superstition and a false belief in regard to the supernatural element in human life are responsible for the mistaken notions of the Chinese as expressed by many of their curious customs.

Beginning somewlat at random, there is a custom which prevails at both Soochow and Shanghai that when one sends a cat to his neighbor as a present the latter in return sends a small quantity of salt. The reason is that to give a cat is bad luck and 
will bring liarm to both the giver and receiver and to comnteract the evil it is necessary to return a present of salt.

Without hesitation a Chinese will believe in things of the most inconsistent and contradictory character. Here is a Buddhist priest, who represents the religion in which a majority of the Chinese believe, and who officiates at funerals and says mass for the dead, yet, the priest is not always held in esteen. Often the people laugh at his mummeries, despise his laziness, and will attribute to him almost every vice. At Soocliow this contradictory belief is founded upon the fact that it is bad luck if, on leaving home in the wlorning, the first person n11et with is a Buddhist priest. The fear is that it will bring calamity, but the ingenuity of the Chinese has invented a way out of the trouble, and when one so meets a priest he has only to raise his hand above his head when all calamities and bad influences vanisli.

While passing along the streets of a Chinese city there may frequently be seen walls erected in front of the doors of residences. The size of these screen like walls measure according to the financial 
condition of the inmate of the house. Sometimes the screen wall is erected close to the opposite side of the street in front of the door, or it may extend several feet from the street and is made somewhat in the shape of an amphitheatre; the space enclosed is usually paved and shaded by trees or shrubs. A careful inquiry as to the canse for erecting the screen wall elicits the information that it is built to protect the house from evil spirits.

The shooter will not be long in observing that to the Chinese mind the whole atnospliere is filled with evil spirits seeking to harm the people, but as a defense to the evil intents these spirits can only travel in a straight line and have no power to turn a corner, and by building a wall in front of the door entrance into the house is made impossible.

Another peculiarity with reference to the front doors of Chinese louses, facing the streets, is that no two doors are placed opposite each other across a street. To place the door of one house opposite the door of another across a street is considered bad luck, because if an evil spirit should happen to get into one house it 
would have easy access to the house on the other side. Occasionally the exigencies of the location require the doors to be placed opposite each other, but when such is the case it will be observed that one of the doors is turned a little to the side or set back and not parallel with the wall.

Another custom based on the fear of evil spirits is that when a new house is being built it is of the utmost importance that the comb of the roof should not point to the door or window of any neighboring house, otherwise it may lead the evil spirits into that house and bring sickness and death and other calamaties to the inmates. This particular superstition is widespread among the Chinese, is a deep seated belief and difficult to eradicate from their minds.

There is a custom which relates specially to the beggars and is strictly adhered to by them. The beggars have a trade of their own and, like many other trades in China, is organized into a regular guild, having a headinan known to foreigners as the "Beggar King." When one gets too lazy to work or is rendered incapable by disease 
or is crippled he can join the beggar fraternity by paying thirty dollars which ensures having his name enrollcd on the book kept for the purpose. After paying his dues and being enrolled he is then permitted to exercise his calling on certain streets of a city or some other designated place; but he must keep within the bounds which will be marked out or suffer a severe punislment for any transgression. At stated periods there must be paid to the beggar king a certain per cent of all sums collected. Many parts of a city, especially entrances to the larger temples, are infested by beggars who are often persistent in their clamor for alms from the passer by. They seem to be instinctively aware that those who visit the temples to worship are in a more religious frame of mind and consequently more ready to yield to their solicitations for money. The Chinese government does not appear to have any method to deal with these indigent people of the country and they go at will seeking a precarious living and sometimes proving very irritating. The annoyance they cause to the shopkeepers of a city is sometimes of extreme irritation, as from one to a 
dozen will collect in front of a shop and sing and beat on a broken gong or anything else that will make a noise and worry the the shopkeepers until in sheer desperation a small piece of money is thrown to them, when the gang will move on to another shop to repeat the provoking song and noise. If the shopkeeper should report to the police the beggars would possibly be arrested and punished by the magistrate, but such a proceeding would prove ultimately expensive, and the more effective way has been adopted by the shopkeepers of paying an annual tribute to the beggar king. The amount having been agreed upon and paid the beggar king sends a representative who posts on each of the tributary slops the Chinese character "to see." All shops that have this character so posted are exempt from further solicitations, and a beggar will not importune that slop so long as the notice remains where he can see it.

Somewhat allied to the beggar question is the thief question, for in the country it is understood that the beggar of the day is the thief of the night. 
The theives are also organized and have a head man, thougli the organization should not be confounded with that of the beggars. Each thief is assigned by the head man to a definite destrict and is thereto restricted under a penalty if he violates his instructions. If there has been much stealing in a neighborhood it will stop at once if the neighbors will pay tribute to the "lking of the thieves." It does happen that this head man falls into the clutches of some greedy official and is made to disgorge, and if obstinate he is "put to the question."

Perhaps no people in the world are more completely subjected to the belief in good and bad luck than tie Chinese. Every phase of their life shows that the idea of fate or luck pernieates and influences the entire fabric of their society from the En11peror to the peasant; a fact that has been noted by writers on "things Chinese" as a marked characteristic of the people; their confidence is every day a striking manifestation of this belief. The luck day in the year and almost every hour of the day is good or bad for something, and the lucky 
and unlucky day has been, as near as possible, reduced to a science. The main object of a Chinese almanac is to give information on what is lucky and what is unlucky for every day of the year, so that when the almanac is obeyed there results a feeling of assurance that bad lick has been avoided on one hand and on the other good luck has been secured. And not only are the most important affairs of life governed by this principle, but all the little details are rigidly brought under its control-the domination of the almanac.

Lucky days are selected, not only for marriage and funerals but for the small incidents of daily life, such as shaving the liead, buying a new suit of clothes, taking a bath, starting on a journey, breaking ground for the foundation of a new house, and starting a child to school. Days are selected for these affairs of life and even the hour of the day must also be chosen witl care.

Good or bad luck follows the student when he goes to the classic examination halls to apply for a degree. If he succeeds he will leave convinced that good luck was the potent factor in his success, but if he 
fails it is attributed to his bad luck. And so this thing, not worthy to be called a principle, is instilled as a part of Chinese education and recognized as fundamental in shaping character.

It is not unusual to see among the poorer classes, especially the farmers, a small boy with a ring in one of his ears. The purpose of wearing the ring is to deceive the evil spirits into believing that the boy is a girl so that they will not take him away; it is believed that evil spirits delight more in causing the death of a son, who is appreciated in the Chinese family far more than a daughter, and these spirits are supposed to care nothing for girls.

Travellers along the roads around Shanghai are familiar with the sight of holes in the brick vaults built over coffins scattered over the country. The holes are to allow the spirits of the dead egress and ingress at will. The Chinese believe that every person has six ghosts and three spirits. The ghosts apparently perish when the body dies, but the spirits continue to live, one going to purgatory to suffer the penalties due for the sins committed in this life; the second spirit goes into the tablet placed in the ancestral 
hall where the sons of the deceased worship at stated intervals throughout the year, and the third spirit remains with the coffin and goes to the grave. As holes are left in the vault it would appear that the number three spirit may want to come ont sometimes and go about, but the Chinese believe that when this spirit comes out it is for misclief.

A curious custom prevails in the city of Huchow in connection with a bridge which spans the principal canal which runs through that city. When a boat passes nuder this bridge no one in the boat is allowed to speak; when a boat is approaching the bridge the boatman will stamp on the deck or make a noise to direct the attention of all on board to the fact that the boat is about to pass under the bridge and all maintain the strictest silence until the bridge is passed. There is no doubt in the belief in the country around and in the city also that if anyone speaks while passing under the bridge he, or some one related to him, is sure to be overtaken by some great calanity, and if the boat shonld meet with an accident it is immediately concluded 
that some one spoke while it was passing under the bridge.

One will frequently meet Clinese of both sexes with very long finger nails. As a rule they are members of the better class of society, and the long finger nails are the badges of respectability. In order to protect the finger nails and promote their growth they are sheathed in tubes made of bamboo, silver or gold; they show that the owner does not have to do nuanual labor for a living.

The Chinese have a great fear of conflagration and yet their houses are built in such an inferior manner as to invite the element they so much fear. In their cities and towns the lionses are close together, and their protection against fire is wholly inadequate. They believe that the god of fire canses conflagration, hence in every city or town may be seen one or more temples to the god of fire. There is a superstition among the people that it is dangerous to talk about a conflagration in ordinary conversation, fearing that the god of fire might hear it. This is the same feeling that prevents them from speaking about 
dying during the first days of their New Year, believing that if one uses the word "to die" during these days it will bring sickness and death either to the one who spoke the words or to some one who heard them.

Turning from fire to water which, according to Chinese philosophy, overcomes fire in the battle of the elements constantly going on, the belief is practically universal in China that the water system of the world is under the control of the two dragons, one called the long, which governs the rain, snow and hail, and the other called the kiao, which governs the water on and under the earth. During a rain storm, or it may be before it comes, people often say they can see the dragon (long) in the sky. Some fantastic shaped cloud attracts their attention and they say it is the dragon making rain. On the other hand when a great flood occurs, sweeping away towns and villages and crops in the plains, it is then said that the earth dragon (kiao) has broken out and caused the flood. The earth dragon appears to keep himself concealed, but if in the neighborhood of the flood a lizard or 
peculiar kind of water snake is seen the people say it is the dragon.

This belief in the dragons seems to have a strong hold upon the mind of the Chinese. Even at Shanghai, in the presence of the highest conditions of western civilization, the dragon festival is strictly observed, and at the appointed period the river and creek are covered with boats filled with the votaries of the belief.

It is attested by the observation of many residents in China that when one has committed a crime or is plotting to do so a thunder-storm will sometimes frighten him into a confession of the intended act, and the confession is made under the belief that it will tend to avert the wrath of the god of thunder. If one is struck down by lightening the Chinese say that it is a punishment for some crime secretly committed. The gor of thunder has his temple also and worshippers at its shrine, and often the worshippers will abstain from eating animal food for a certain number of days in loyal obedience to their god.

Among the strange things that impress a student of Chinese life is that the most 
contradictory and self-destructive beliefs appear to exist side by side in the mind of the same person, and of the most opposite character mentally and morally. In many ways the Chinese are kind hearted and considerate and at times the most callous hearted. If a man or boy catches a rat he will nail its feet fast to a board and keep it there until the rat starves to death, and if one falls into the water and is in danger of drowning, no matter how many Chinese are near or how many boats nay be passing, no one will lend a helping liand to get the man ont of the water. The reason for such callous indifference is the belief that an evil spirit lias got hold of the man and that if anyone goes to his rescue the evil spirit will also attack the would-be rescuer and canse lim to be drowned.

The Buddhists have a way of destroying the power of the evil spirits of the water. Passing along the canal at Soocliow one may see stone posts, each with eight sides, planted in the gronnd on the shore of the canal, and on each face of a post there is the name of a Buddlist saint. 'The posts are planted along the banks of the canal where 


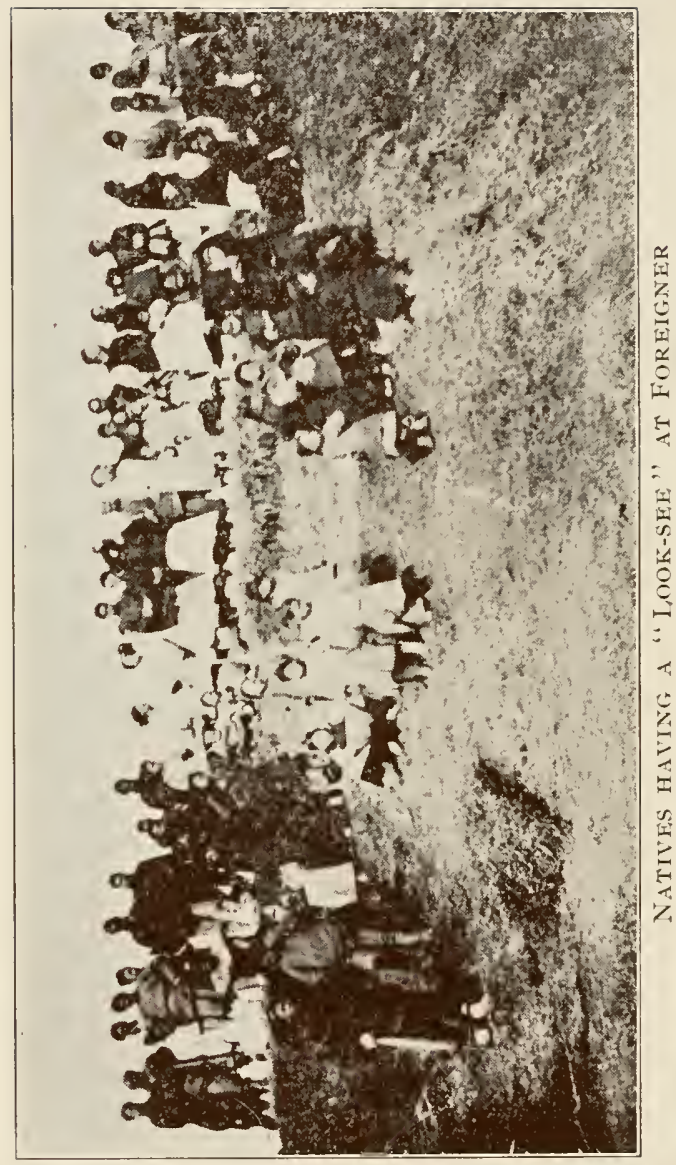


persons have been drowned, and the belief is that the evil spirits are afraid to go again to the place guarded by one of these posts, and that no one can be drowned near where a post is planted.

There are so many curious customs in China that a large book could be written about then, but I have referred to a few only, and the shooter will observe many more if he shoots in China for any length of time. He slould remember that the Chinese are the antipodes of the westerner, not only geographically, but socially, norally, mentally and politically. Their manner of life naturally seems upside down to a westerner, for where the latter wears black for mourning purposes the Chinese wear wlite, and, in meeting, a Chinaman shakes his own hand and not the hand of his friend as in the west. At the table or elsewhere the place of honor in China is on the left hand and not the right as in the west. They read their books from top to bottom, beginning at the riglit and reading to the left. In the west the notes of an author or a commentator are written at the bottom of the page while Chinese authors or commentators write theirs at the top. 
256 SHOOTING IN CHINA

Their entire social fabric and the idioms of their language are materially the reverse of what it is in the west. And when the Clinese are reminded of such a radical difference they answer, that China is the oldest nation in the world, knows her interest, and that the young nations of the west can learn lessons from China. 
GOVERNMENT 



\section{CHAP'TER X.}

GOVERNMENT.

In the first chapter I snggested to the shooter that if he began shooting in China with some idea of the peculiarities of the langnage, the people, and the money he would sometimes experience an advantage which would more readily enable him to overcome a real or avoid an apparent difficulty.

In this chapter I will submit a few general observations on the government of China, and the law the foreign shooter will be anenable to, should he offend, and the legal remedy that will be employed against him while in China. If I succeed in presenting a practical view of this subject I shall not feel that I have materially digressed from the title of this book; and it is proper and interesting to know something of the govermment of the country in which a sojonrn, even for a short time, is made.

In theory and practice the government of China is as peculiar and as mixed as the 
people and the language. Probably, in theory, there was never devised a more symmetrical and harmonious system for any monarchical form, ancient or modern. When solely studied, as a theoretical plan of government, one is compelled to admit and adnire the nicely adjusted proportions and the evenly distributed duties and responsibilities, but when the practical workings are studied there appear many inconsistencies and much to condemn.

For territorial administration China is divided into about thirteen liundred districts, exclusive of Manchuria, and in each district there is an official known as the district magistrate (Che-hien). This officer is the last connecting link between official China and the people, and one of the most important in the entire administrative system. He is the nearest to the people; his relations to them nore intimately concern their welfare, as the daily life of the people of the district are nuder his immediate supervision. When the magistrate of a district is just and upright in the performance of his duties the inhabitants are usually peaceful and prosperous, but an evil disposed and dishonest magistrate is a 
disturber of the public peace and may cause nnich annoyance and trouble to a foreigner travelling through or shooting in his district. It is, therefore, important for the shooter, should he have real trouble with the natives, to ascertain the temperament of the magistrate and thus be prepared to approach him through a channel that will conciliate him, or an agency lie fears.

If the shooter should be shooting in the interior, some distance from his consular representative, he ought to go at once, in the event of trouble, to the district magistrate, and in a friendly and pleasant manner inform the magistrate of the exact nature of his trouble. And, in this connection, I will state that I have never net a magistrate in China who was not ready to listen attentively to any statement I might have to make, and as ready to redress any wrong. I recall with pleasure the occasion when I was shooting more than two hundred miles from any open port, and could not use the paper money I had, and a magistrate provided me with the amount I needed in silver. I know that some of the troubles between foreigners and natives are provoked by the foreigner, and there are others that 
conld have been prevented or greatly modified if the foreigner had behaved as a gentleman should at all times.

Proceeding from the base to the apex of the administrative system, the next in order, after the district, is the department, which division includes several districts. There are about one hundred and eighty departments, and each is presided over by an officer officially styled the prefect (Che$\mathrm{fu}$ ). This is said to be the earliest division of the administrative system, the duties of the prefect removing him farther from the people than do the duties of the magistrate, and making his office the court of appeal from the magistrate.

After the department comes the circuit, which is formed by the grouping of several departments, and is presided over by an officer whom the Chinese designate as the intendant of circuit (fen sun tao or taotai). To foreigners, however, the intendant of circuit is better known as the taotai, and it is this official who sustains, at the treaty ports of China, the more intimate relations with the consular representatives of western nations which 
have treaties with China. There are eiglity circuits, but the nore important include the principal treaty ports, and if the shooter should become involved in a difficulty, which he thought necessary to refer to his consular representative, it is probable that such representative would first communicate with the taotai on the subject. This officer, when residing at a large treaty port, like Shanghai, is expected to keep himself well informed about foreign affairs, as his official superiors frequently demand of him lengthy reports as what appears to be the policy of the westerners residing at his port. When away from an open port, and the shooter believes that the district magistrate is indifferent to his representations it would be advisable, if a taotai is near by, to ask permission to see him, and should the magistrate hear that such was the intention of the shooter it is very likely that he would promptly afford the proper relief. An under official sincerely deprecates having his action reviewed by a superior.

It has been stated that China proper was divided into eighteen provinces, and the territorial division, for administrative pur- 
poses, after the circuit, is the province. Over each province an officer presides with the title of governor (sun-fu), and his official residence is in the chief city of the province, which then is known as the provincial capital. There are several officials nuder the governor and whose duties are carefully prescribed, but the shooter will have nothing to do with these officials, but go direct to the governor, should the urgency of his business justify appealing to such a high officer, and there may arise occasions when the appeal is necessary. The several officials, as 111any as five, referred to, together with the governor as the head, form the burean of prorincial administration. As the district nuagistrate is the last connecting link: between the throne and the people, so the governor is the essential link between the central and the adninistrative system.

And there is another fact which proves the influence of the governor, for $11 \mathrm{p}$ to abont three hundred years ago he was the officer of highest rank in a province, and practically supreme therein. But subsequently two or more provinces have been mited under the execntive authority of an 
official who is styled the governor-general (tsung-tul1), but better known to foreigners as the viceroy. Both in theory and practice the viceroy is really the superior of the goverior, but it is very seldom that he asserts it. On the other hand these two officials are extremely conrteous and considerate, and one seldon withlolds his approval from the known wishes of the other. A viceroy has his personal staff and subordinate officers wlose duties are more or less clerical. If the shooter should believe that he was compelled to see a governor or viceroy he would find lis way smoother if he made the acquaintance of some favorite secretary and was pleasant to lim.

Although a governor and viceroy are officials of high rank and great influence, the shooter will not fail to notice the military establisliments in the provinces. And here I should inform hin that the present ruling dynasty of China is not native but of tartar origin, and for that reason the military establishments are under the conmand of military officials of tartar extraction, and known as tartar- 
generals. These tartar-generals appear to outrank both the governors and the viceroys, for the imperial edicts are addressed to the tartar-general, the governor-general, and the governor, thus showing that the emperor regards the tartar-general as the first in grade, as his name appears first in the edicts.

But let the shooter keep away from the military establishments. He will have no business with a tartar-general if he attends to his own.

Now I have introduced the shooter to the territorial divisions for administrative purposes, and indicated the head officials of each division. If he should get into troubie, I have pointed out the officer to whom he should apply for relief, if he is too far from his own consular representative to make the application direct to him.

The divisions to which attention has been directed form the practical agencies by which China is governed. I have stated that the government, when contrasted in theory and practice, was as peculiar and as mixed as the people and their dialects.

The Emperor, in theory, is absolutely supreme, but in practice the provinces are 
as so many independent sovereignties with their viceroys in command. If a requisition is made on a viceroy for a certain amount of money the viceroy proceeds to collect the amount he may wish, and after paying the requisition of the emperor accounts to limself for any balance. If money is scarce in a province, and the viceroy desires to do so, he establishes a mint and coins what he wants. In theory, the taxes are levied in accordance with equity, but in practice the amount is fixed and collected as the provincial officials may need a large or a small sum. This illustration will suffice to prove the statement, that the theory and practice of the government are materially different, for a chief function of an absolute ruler is the regulation of the money of his empire, how it shall be coined, and how taxes sliall be collected, two of the most important attributes of sovereignty, and with which, in China, the emperor practically does not appear to concern himself.

In practice, each province exists as an independent unit and is sufficient unto itself, and this is a pivotal fact which should be constantly kept in mind when studying 
the govermment of China. If the administration goes on smoothly in the provinces the officials therein do about as they please. But there have been occasions when the people of a province liave felt themselves oppressed by their provincial officials, and they have very summarily resented it. It is an unwritten law of Clina that the people have the right to dethrone their Emperor when he does not govern wisely and justly. While they recognize the Emperor as the son of heaven, they say that he ceases to be sucli when he fails to live up to the dignity and requirements of his high station. There is a beatiful idea in this principle, for it means that a ruler ought to govern by the highest standards of virtue and equity.

The shooter will rarely, if ever, have such a case as will necessitate his going to Peking to enlist the support of his diplomatic representative. But as I have presented an outline of the divisions of the territorial administrative systew1, a brief reference to the adninistration of the system of the central government nuay be added. 
The Emperor is the source of all power, but the administration of the central government is entrusted to two comcils, known as the grand secretariat ( $\mathrm{Nui}-\mathrm{Koh}$ ) and the grand council (Kiun Ki-ch'u). The grand secretariat is of greater antiquity than the grand conncil, and has been the more important division of the cabinet from early times. This grand secretariat is composed of four members who sustain the closest official relations to the Emperor; they submit to him all papers relating to the affairs of the empire and receive from hin the instructions necessary to the preparation of official edicts; they keep the seals used for the departments and documents, and are the four officials whom it is supposed the Enperor more frequently consults. The grand council was provided for in 1730 . The members are generally chosen from among those of the grand secretariat, the presidents and vice-presidents of the boards, and the principal officers of all the courts in the city of Peking. This is the division before which the boards of the departiments appear when the Emperor is to be consulted. In theory both the grand secretariat and the grand council have daily 
audiences with the Emperor, and practically such andiences are necessary to facilitate the transaction of business. In recent times the grand council has superseded the grand secretariat in the transaction of business, and has becone the imperial chancery or conrt of appeals. Under the two councils there are six administrative boards ( $\sin \mathrm{pu}$ ) and each board has an organized staff of clerks, and is otherwise equipped for the business it was formed to transact.

There is certainly a special and imperative reason why the foreign shooter should behave himself while shooting in China, and it is because he is not as a rule under Clinese law. Whatever offense he may conmit, and however heinous in its nature, against life and property in China, the conrts of China are powerless to arrest or to punish. This is in accordance with the treaties which Clinia has entered into with certain western nations. If the offender is the citizen or subject of a nation having treaty relations with China he will be exempt from Chinese law, but not otherwise if his country has no such treaty relations, for then he would be anenable to that law. 
If the shooter should be in the interior when he offends and it is not convenient to complain to his consular representative, the Chinese authorities may bring him before such consular representative, but they cannot arrest or punish him by any legal process of their own. The shooter should not hesitate to see his consul, and if he has any doubt as to the justice of the demand against hin when made while in the interior let him give the benefit of it against himself, and go and put himself and his interest in the hands of his consul.

The authority with which each consular represntative is invested by the treaties is the origin and fondation of the doctrine of extra-territoriality as applied to China, and although Chinese statesmen have of late years complained of the injustice of this doctrine the facts of history do not warrant the complaint. Before western nations had relations of any kind witl China there were foreigners residing within the empire who were not subject to her laws. During the eighth century Arab traders resided at Canton, and with China's willing consent governed themselves by their own laws. In 
his commentaries on the criminal law of China, Alabaster maintains that the Mohammedans have also long resided in China as a distinct element of the population and amenable only to a separate law as administered by their own anthorities. At Macao, not far from the present island of Hongkong, the Portuguese settled centuries ago, and carried on trade subject, all the tine, to their own laws. And when the Dutch, the Spaniards, the English and other nationalities made their advent into China, and were assigned trading places at Canton, all were left to manage their own affairs in their own way.

But, on July 3 rd, I 844 , China surrendered in regular legal form the jurisdiction she might have thonght to have reserved over all foreigners within the empire whose nations were in treaty relations with her. The treaty I specially refer to was that made between China and the United States, the latter conntry being represented by Caleb Cushing. As this treaty lias served as a model for subsequent treaties I will copy the words which directly applied to China the doctrine of extra-territoriality. They 
are found in article XXI ano are as follows :

"Subjects of China, who may be guilty of any criminal act towards citizens of the United States, shall be arrested and punished by the Chinese anthorities according to the laws of China. And citizens of the United States who may commit any crime in Clina, sliall be subject to be tried and punished only by the consul, or other public functionary of the United States thereto authorized, according to the laws of the United States. And in order to the prevention of all controversy and disaffection, justice shall be equitably and impartially administered on both sides."

Four months later France made a treaty with China in which was substantially embodied the article above quoted from the American treaty, and in 1858 it was literally copied into the treaty entered into between China and Great Britain. By virtue of the "most favored nation clause," whicin appeared in the subsequent treaties, entered into by China with western nations, the benefits of the article of the American treaty have accrued to the latter. Certainly 
the United States is the first western nation that negotiated a treaty with China in which it was expressly stipulated that a westerner, althongh residing in China, should remain amenable only to the laws of his own conntry.

And this principle in the American treaty was not extorted from China, although China has of late years contended that she was forced to yield the principle. The fact is, China's whole history proves that she has, at all times, acted upon the policy not to interfere with the person or property of foreigners, and adhering so blindly to this policy she entered into the treaties referred to without due consideration of the farreacling influence of the principle to which she then so readily subscribed.

But western nations would not have allowed China jurisdiction over the lives and property of their citizens or subjects. In many respects the law of China was just, but the way in which it was and is still administered is neither just nor lumane, and the principle of extra-territoriality should be maintained against China, nntil she reforms her judicial system by the stanciard of enlightened jurisprudence and lumanity. 
As stated, the citizens or subjects of the nations having treaty relations with China and who reside in the empire, or who may offend while sojourning therein, are only amenable to the laws of their respective nations, and must be proceeded against before their own representatives in China in strict accordance with the laws of their own countries. And becanse of this fact the foreigner in China should be more considerate of the laws and customs of the Empire. 

NOTES BY AN OLD SPORTSMAN 



\section{CHAPTER XI.}

NO'TES BY AN OLD SPOR'TSMAN.

As I was anxious to conclude these papers with a reniniscence of the early years when the westermer shot in China I turned to my friend H. T. Wade, wlio was an early day sportsman and one of the best informed on the subject, for the information desired, and he has very kindly given me the following interesting notes :

The looking up of old sporting records is at best but a sad and sorry occupation for so many of the participators in the sporting incidents of earlier years have long since passed over into the dark, lone land. Yet a few notes from a diary kept with some regularity for the past forty years nuay, perchance, still possess some little interest for the enthusiast of to-day.

I remember ny first slooting trip in China as clearly and distiuctly as if it were but an event of yesterday. It was in December I 866, a few days after iny arrival in Shanghai. Onr party consisted of three guns, and our liouseboat, coufortable, nay even luxurious as we considered in those 
days, would have been lauglied to scorn at the present time. There was no stove in the boat, and onr washistand was but a pewter basin dunped down upon the deck. Fagged out after a hard day's tramp our first care was to pump ont our muzzle-loading guns with ice cold water, a very dirty opcration; and the second to clean ourselves, also in cold water, before getting into our thick fannel dressing gowns and drawing on onx skin-lined mandarin boots. Kashing, I remember, was our centre of operations, all anongst the ruins around the city walls, before the tens of thousands of tons of rubble were thought of for macadamizing the roads of the Settlement of Shanghai. It snowed hard during the week of onr short trip, and the innumerable ponds were alive with wild fowl on such ice free water as could be found. 'There was nothing very remarkable about our sport for our bag rarely exceeded double figures per gun per day, but there vas a keenness, an enthusiasin, a je ne sais quoi about the outing which, I take it, scarcely exist to-day. Perhaps I may explain what keenness meant. I had just arrived from home with no shooting boots, of course, but only some half dozen 
pairs of ordinary walking boots. Long before our week's holiday was up not a single pair of $111 \mathrm{y}$ boots could boast of a sole. 'The binding snow and the sticky mud, when the thaw came, left me minus of all but the uppers.

Two shooting trips nemorable from the aquatic incidents of each come vividly before me.

In the winter of $x 867$ I started off on the Grand Tour which, at that time, included visits to Kashing, Soochow and the Nadoo country. My companion was Mr. George Butler, who is still alive and here to confirm the story. Our trip was to be an affair of three weeks at least. The boat was well stocked, and off we started at 8 o'clock one morning, a strong northeasterly wind driving up the spring flood tide. No sooner were we nuder weigh than an Exanination of our shooting paraphernalia took place, when to our early and intense disgust it was discovered that my comrade had come away minus his cartridges. There was no help for it but to tie up the boat on the Pootung side of the river opposite to the French Concession, cross the racing stream 
in a very uncertain sampan, and make our way to Mackenzie's store where we had to wait until 400 cartridges were loaded, which took a longer time in those inexpert days than would be required now. By the time we got back to our boat the tide had turned, and nilly willy we had to remain at anchor until that night. The loss of a day in a three weeks' trip does not appear much in these more philosophical times, but then it seemed an eternity. Nothing unusual occured during the trip until we arrived at E-Shing. As evening drew on we saw our nasthead light at 110 great distance. Butler made straight for it, while I making a longer and circuitous route found finally that a broad bridgeless creek cut we off from our craft. It was now quite dark; no native boats were about, and it became a question of seeking the shelter of a native hut or breasting the water. There was I with four brace of pheasants slung over one shoulder, uny cartridge bag over the other, and my gun. There was not nuch time for reflection and an icy cold swim was the result. And when I landed in the dark how heavy everything was, pound weights seemed to be hundred weights. However, 
an end connes to all things and a half hour's trudge found me in the enjoyment of that comfort which only a houseboat grants. It goes without saying that I should hesitate to repeat such foolhardiness to-day.

Shooting not long ago to the north of the Mowsan, a high range of hills a few miles distant from the city of Kinlang, I happened to strike a small strip of conntry unusually favonred with water considering the droughtiness of the season. Where water was there were pheasants. I had made a good bag, eight brace during the morning, and things were going along nicely enongh until put a stop to by an nutoward incident. I had dropped a cock pheasant across a creek into the open plongh, and ny dog went after it. On his attempting to scramble up the precipitons bank, a native dog, showing an enviable set of ivories, put so much fear into him that my animal was compelled to give up the quest and return to nie. A couple of natives saw my predicament and offered to punt me across. On landing the native dog, a mighty fine specimen of his kind, again began to worry my pointer, but a luckily directed "halfbrick" diverted his attention for a tine. 
Freed from his annoyer my dog began working ont the scent of the bird which by this time had gained the shelter of a small strip of reeds, but no sooner liad he entered the cover than the wonk attacked him in the rear, biting through his foot and rendering my favourite useless for three whole days. And he then began to savage lim in that way for which native dogs have an unenviable notoriety. By this time lialf a dozen reed cutters cane upon the scene. I begged of them to get their dog away; but either they did not or would not understand me, but seemed to enjoy the situation immensely. And there was I with the prospect of a ruined trip before me, a mained dog and no possibility of redress. So after giving then a fair warning, in order to save my own dog I had 110 recourse but to sacrifice theirs. Now the music began in earnest. I had killed the best dog in Clina, and they swore by all their nine gods that they wonld do both for me and my belongings. My situation was-well, to say the least-awkward, for their business like sickles were horribly ugly looking, and I found to my horror that I was upon an island. There was no time for delay so 
I gradually made my way to the punt. But here again another trouble arose for the punt evidently was family owned, and the craft was being rapidly shoved out into a wide lagoon. Again addressing them in language, more forcible I fear than polite, I shouldered my gun butt upwards, walked into the water, and swam the 40 feet of creek. The dervishes were dumb for a monnent, then calling for the punt, they made a rusl to get into her simultaneously; with the result that she turued turtle, and it was some minutes before she had been baled out and was ready for use, when to my joy pridence had enjoined them to cross over two at a tine. 'l'his, of course, gave nie a chance to "get" and I got, but a keen north west win in my face, my garments alnust freezing on me, and no hope of a change until a three mile walk had been acconplished was not the pleasantest of experiences. Well, the long and short of it was, that I fually got out of an ugly mess, and I still wonder what anyone else could have done under the circuninstances. It seemed a cruel thing to shoot the native dog. But I had no alternative if I would save my own. 
Arguments as to the weights of different kinds of gane only too of ten arise, that of suipes in particular. The largest suipe I ever saw was shot by the late Wm. Cooper near the Three Water during the eignties. He bronght it on board my boat, and weighed on a little scale I happened to have with me, $81 / 2$ ounces. It was a Swinhoe. I have seen a few birds since which drew 8 ounces, but I do not know that a heavier than the above mentioned bird has ever been shot.

Woodcocks sometimes run to a great weight. Veisch, of the Hongkong Bank ouce shot a cock that weighed rather over I 8 ounces, while I myself once accounted for a woodcock shot on the Bubbling Well Road, close to the Race Course which the day after being killed weighed 6 ounces. The presumption is that it weighed nore than this when freshly shot.

Of the prolificness of the common river deer there are many instances. One instance I specially remember. The deer was shot by Mr. Wm. Cooper, and on being opened by Dr. Henderson and myself the uterus was found to contain seven embryos. 
Four and five young at a birth are not at all unconmon occurrences.

A very extraordinary thing happened when I was shooting with the late Mr. Walter Plipps. We were working down the banks of a creck, one on each side, not far from Changchow on the Grand Canal. My dog put up a hare which nuale for a small stone bridge which crossed the creek. Phipps' dog happened to be at the other side of the bridge. Puss was so terrified that she made a mad jump right into the jaws of n1y companion's dog, a big black retriever.

There must be a very strong and attractive scent about hedgreliogs. Once when near the Fonr IVaters on the Sooclow Creek, a spaniel I had brought me in rapid succession from amongst some old coffin and decayed timber seven tightly rolled hogs. The artistic manner in which the dog first tackled the quills and then tenderly carried the aninual was a sight worth renembering.

The sanie dog once brought me four leverets from the same nest, which I only discovered by following the animal returning for more, where was yet a fifth. It is 
needless to say that iny companion, Mr. Simpson of the Old Dock and I carefully conveyed the helpless little ones in our handkerchiefs back to their home.

That weasels, the little red Siberian weasels, are very prolific all over North China is common knowledge, but few people are aware that export of their skins, as can be seen in the Custonns returns, amounts to millions in the conrse of a year. Very ingenious too, are their many modes of capturing vermin, but the commonest and nost fatai is by means of the old fashioned Springe. In 1890 at the month of the Pejoo creek we were witnesses (Tripp, McKie, Stewart and Orman) of a successful night's work. The occupants of three small boats were skinning, as fast as deft fingers could do the work, the previous night's catch of weasels. A cross slit over the nose enabled the operators to get their fingers inside the skin which they drew back over the body inside out merely chopping off the obstructions caused by the legs. The carcases, valuable as food, were offered for sale in the Pejao market, while the feet, fry and tails were were put aside as tit-bits to be enjoyed with their well-earned rice. 
We estimated that we saw at least fifty animals thus treated. The pelts were taken into the city whence with thousands more they were shipped down to be cured in Shanghai. There is no doubt but that these weasels cause sad liavoc in the native farmyard, and that these trappers make a good livelihood.

I was shooting with my friend Simpson of the Old Dock on the Grand Canal about I 5 miles S. W. of Kashing. The morning was all that could be desired by the ardent sport, and the country which already looked inviting looked doubly so when a brace of woodcocks gave us a sample of their quality. I dropped one as he was disappearing behind the angle of a copse, when suddenly I heard a cry of anguish far away to my right. On proceeding to the spot whence came the cry a native came towards me with his face well smirched with blood. On examination I found that a spent shot had cut the skin on the bridge of his nose. After staunching the blood-flow with a bit of cotton wool I offered him some sinall silver which to my surprise he refused as the affair, so he said, was pure accident. Considering the 
incident at an end I was hastening to rejoin my companion when appeared in the scene Madame, the conntryman's wife. She prored to be "an impossible," and after opening the flood-gates of her wrath and vilifying me in the choicest Billingsgate accentuated her words with blows laid on with no light hand. Then appeared upon the scene, from the most impossible places, such a crowd as only China apparently can summon at call. And in a moment I found myself being belaboured by old women and children, and by arms round my neck and legs which held ne a tight prisoner. A few words from my dog coolie, who probably told them that I was a much bigger personage than they imagined or that I really was, brought abont a palaver with the result that I was to go with some of the elders to the Mandarin wlıo lived some distance off, and that my coolie with my gun were to be detained as bait until my return. I had not proceeded far when second thought on my escort's part prevailed, and I was locked up in a Joss house four hours until they lad arrived at some definite conclusion as to what shonld be done with me. These four hours seemed an 
intolerably long time, for they were the four best hours of a really fine shooting day. However, an end comes to all things as it did to n1y incarceration, and I was not sorry when a self-elected party of six hefty countrymen said that they would accompany me back to my boat. Meantime coolie and gun remained nureleased. After a tramp of 16 li-five miles or so-to my great joy I discovered that my boat was anchored quite close to a gunboat. I immediately sent my boy armed with my card and passport and an explanation of the affair. The passport appeared to act like magic, for the captain of the gunboat, redolent of a recent pipe of opium, quickly donned his uniform, and made a company of his crew row him back to the scene of the trouble. What took place there I shall never know, but in a conple of hours time gun and coolie were restored to me. The Captain explained to me that the matter was of $n o$ importance and that he had sealed it by the promise of a dollar to the wounded man. I gave him a couple of Mexicans which, doubtless, the cripple never saw.

On my return to Shanghai I laid the particulars of this incident before my Consul 
who must have brought the gunboat's captain's claims to recognition by the local officials, for when a year later I was in the Kashing district, the man called upon me in my boat and told me that he had good promotion in consequence of the assistance he had rendered me, at which news I was glad indeed.

It is not often that one gets deserted by one's coolies when up country. Only twice have I been in this predicament. In 1897 I was away with a friend in his houseboat. His laodah was a bad one and the crew, on this occasion, a superlatively miserable lot. Our trip never extended beyond the fifty mile radius and yet we got left in the lurch. We were in tlie Nakong creek. The laodah came into the cabin to inform us that we proceed no further as there was not sufficient water. To prove to him that there was water and to spare my companion and I, with the assistance of the boy and the cook, poled the boat some ro li, when we landed for a short shoot. On our return at dusk we were told that the crew had "levanted," and as we could get no assistance until we reached Nakong village, we tracked the boat ourselves in a blinding sleet storm. If 
one would know what discomfort and hard work are he should try tracking a boat on a slippery path, in the dark, in pitiless rain. The next morning we discovered our crew in a tea shop in Nakong. On our paying for their night's lodging they promised to resume work. Joyfully we started out on our shoot but ruefully returned when the boy came into the country to tell us that the crew had again decamped. Nothing daunted we poled and tracked the boat to the next village which we reached at ro o'clock at night where we found every one asleep. Our knocks at the door of one poor hut brought out a couple of villagers who said they would help us as far as Taitsan, 8 miles distant, which they did for a couple of dollars, and at which pay they grumbled. At Taitsan we solicited the assistance of a gunboat, assistance which was granted to us in the persons of four townsmen who apparently had never been in a boat before. By slow degrees we reached Shanghai, where the matter was reported to the police, from whom the promise was exacted that they would "look into it."

This occurred eleven years ago, and not having heard anything from them since I 
take it that they are still "looking into it." Seriously, it is very awkward even for those who best know the country ropes to be left stranded.

In the "Sportsman's Diary for Shooting Trips in North China" by Francis A. Groom, I find some well considered hints as to how the shooter should proceed when a disturbance is likely to ensue, and as the hints are as useful now as when written by Mr. Groom many years ago they merit reproduction as an instructive conclusion to the above notes:

A sportsman, when up-country, is liable to get into tronble in more ways than one. The most common occasions of collision with the natives are:

A lostile propensity on their own part. An accidental injury to one of their number.

Abuse or ill-usage of the people by the sportsman's own boat's crew.

In each of these cases, a little discretion and care will invariably avert ill consequences; whereas rashness or impatience may bring about the most unfortunate, and even fatal results. It is difficult to lay 
down specific rules where circumstances must to a greal extent influence individual action, but the following hints will perhaps prove useful as a general guide on occasious of the kind.

Hostility on the part of the Natives.Sportsmen in this or neighbouring provinces will seldom cone across a town or village in which the population itself will be found positively hostile. But they are liable everywhere to meet with disbanded soldiers, braves, and nnemployed rowdies, and these nen are very apt to incite the mob to be aggressive and tronblesome. A grood general rule is to avoid loitering about large villages altogether. But at times even the sinallest populations, as for instance, those of the Ta-sze-jao district, will contain an element of hostility traceable more or less to the presence or influence of such nuen.

The wisest course a sportsman can pursue when he observes signs of an nueasy or angry feeling, is to make the best of his way ont of the vicinity, even at the hazard of a few brickbats being sent after him. But this is not always practicable, and a useful alternative is to distract attention 
for the moment by taking notice of a child, giving it a small coin, or a handful of shot, or by presenting a bird or two out of the bag to an old woman, or even by firing at any bird that may perchance be flying over head.

If the crowd prove very aggressive, and there is nothing for it but a fight, the best plan is to go into a shop or farm house, the more respectable the better, and leave the inmates to deal with the mob whilst an escape is attempted through the back premises. At the same time as bold and fearless a front as possible must be maintained short of acting actually on the offensive.

Violence of any kind will be found a mistake, for numbers must tell in the long run, and the game is not worth the candle. Where a mandarin's poles are anywhere in view, it is not a bad plan to make for them sharp, and if possible, to get hold of the mandarin himself by pushing into his inner rooms, for he will never slow himself otherwise.

Another common cause of annoyance is the grabbing by the country people of game as it falls, and running away with it 
before the sportsman can pick it up. This is best met by prompt action. A sharp blow with the side of the hand on the wrist of the thief, whilst you grasp the game with the other, will be found very effective in inducing a relinquishment of the stolen property.

Accidental Wounding-This is a misfortune to which the most careful and experienced shot is at times liable, for comntry people will lie perdu in the most unlikely spots, jumping up at the very moment the trigger is pulled, and children also have a bad habit of following in the wake of the guns, to pick up castaway cartridges for the sake of the copper capsules.

When a native is wounded the difficulty should be boldly faced, and an immediate endeavour made to ease the hurt, and to make compensation by an offer of money. Should the parties seem inclined to be extortionate, persuade them if possible to adjourn to the boats and talk it over-or to repair to the nearest tepao or mandarin and have the difficulty formally adjusted. Noise and bluster should be met by distinct refusal 
to do anything; should a row unfortunately ensue, remain as quiet as possible, and ratler give up your arms or subuit to be taken prisoner than offer resistance. A case happened last year where some sportsmen who were unaccompanied by Chinese, and could not speak a word of the language, adopted this last course, they were carried before a mandarin, who at once estimated the damage done at $\$ 20 .-$, allowed them their freedom, and returned their guns to them on their promising to send the money to him after their arrival at Shanghai. This occurred near Ta-sze-jao, the most troublesome district in the province.

Ill-nsage of the Natives by one's own Boatmen.-This is a fruitful occasion of offence to the people, the boatmen being always only too ready to rely on the presence of foreigners to steal vegetables, fruit, fuel, or any other articles that come convenient, and even to rail at and bully other boat people, whow they meet on the canals. The remedy is sinple, and a preventative has been suggested elsewhere. The sportsman should be most stringent in enforcing lis prolubition against such malpractices. 
In connection with the above hints, it would seem almost superfuous to suggest the necessity of great cantion on the part of the sportsman himself in refraining from annoying the natives in any way; crops should be respected as far as possible; traps for game left standing, and $\operatorname{dog} s$ and cats slonld not be molested, even when fonnd poaching. The people as a rule are so well inclined, that a sportsman can very well afford to forego his mischievous, or even reasonable tendencies, rather than destroy the cutente cordiale which it is so much to every one's interest to maintain intact. 

VOCABULARY 



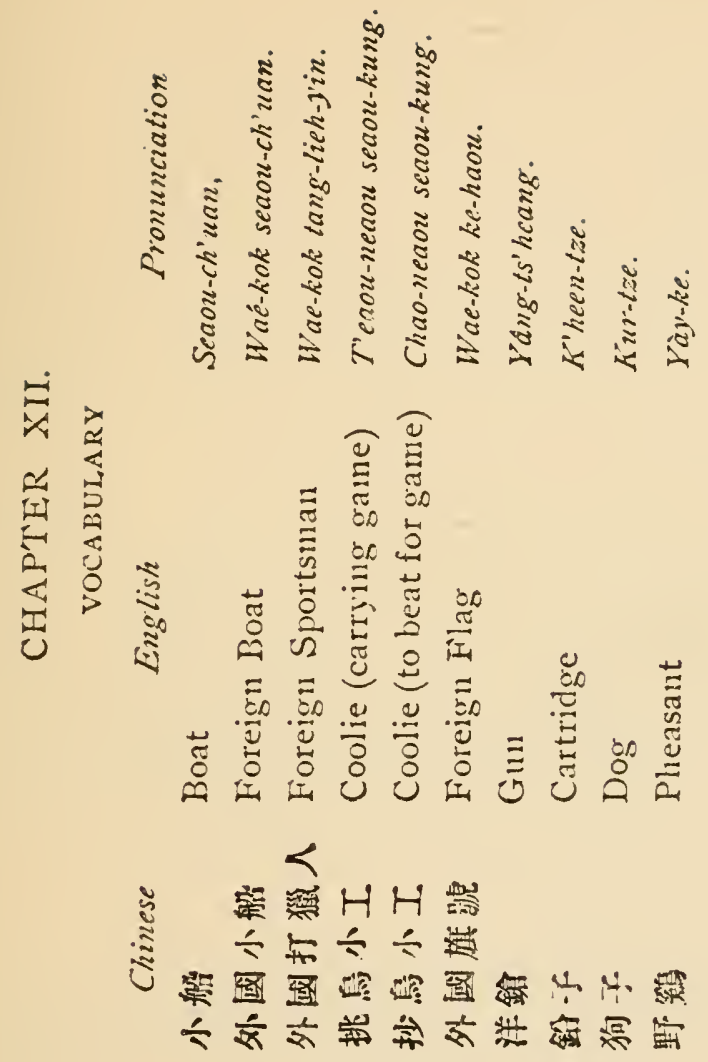



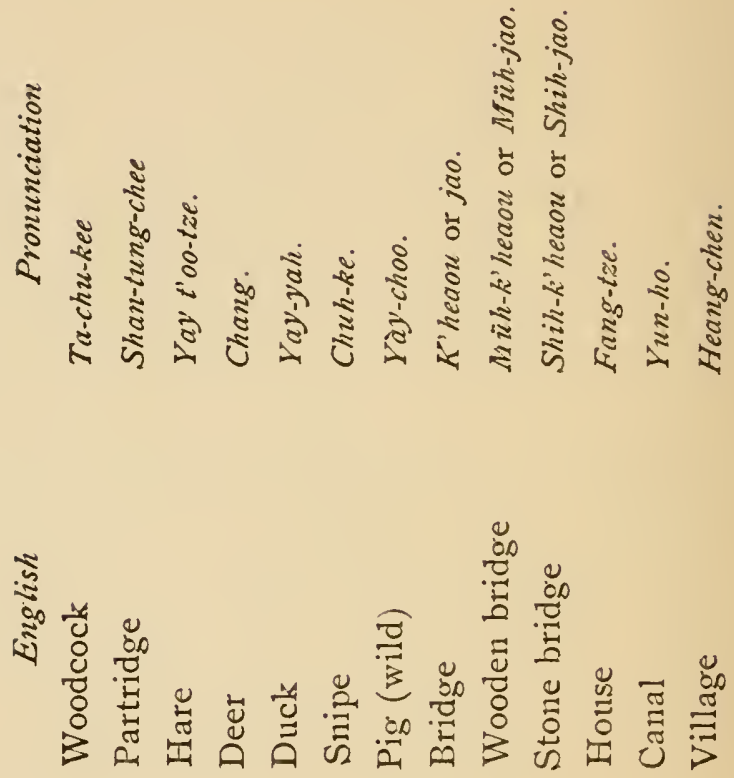

¿

होic

Uे

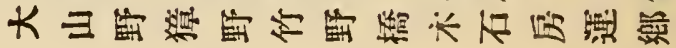



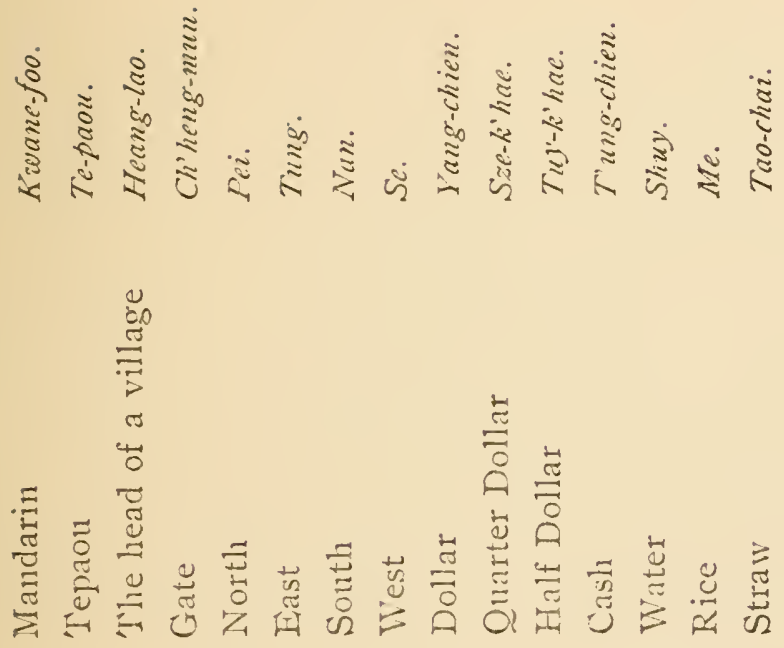

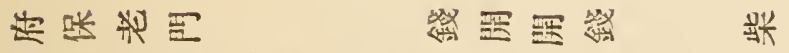

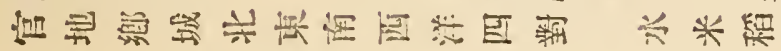





\section{CHINA IN LAW AND COMMERCE. \\ By T. R. JERNIGAN. \\ PRESS OPINIONS.}





\section{CHINA IN LAW AND COMMERCE. \\ BY T. R. JERNIGAN.}

\section{PRESS OPINIONS.}

In addition to his honorable record in the consular service of the United States Mr. Jernigan has placed English reading people under further obligation by issuing what is probably the best single volume for all who have practical relations or business with the Chinese . . We know of no book that enables one to see as clearly those differences in the great Chinese mass which have been wrought by the physical influences operating through thousands of years.

THE NATION.

It is refreshing, after having read the many recently published interpretations and attempted interpretations of Oriental life and character, to turn to so practical a work as this of Mr. Jernigan . . . The inquiry is historical rather than physological, but the result is an exposition of Far Eastern methods of thought and conduct that is far more illuminating to the Occidental nind than most, if not any, of the fine array of volumes devoted to the minute dissection of Oriental motives and mental attitudes.

NEW YORK TRIBUNE.

The book is packed with concise and practical and important information. We have rarely come across one that could instruct better in the ways of a strange civilization those who are willing to learn.

NEW YORK SUN. 
It is pleasant to be able to record that success has attended Mr. Jernigan's efforts, and that from his pages one may glean not merely knowledge of the political and commercial life of the country, but a better understanding of the Oriental mind.

THE OUTLOOK.

In this admirable work Mr. Jernigan, who has long held a high position in the United States Consular service in China, has contributed a volume which will be indispensable to every student of the civilization of the Far East.

INDEPENDENT.

The book shows throughout an intimate knowledge either of the facts themselves or of authoritative sources of information, and where it ventures on hitherto unexplored paths seems to deserve confident acceptance.

THE CHURCHMAN.

Mr. Jernigan gives us as much information as can well be given in the same space; but his book is no mere collection of facts. The Chinaman's point of view and the Chinaman's character are so well shown that his customs and laws do not seem strange.

CHRISTIAN ADVOCATE.

Careful study has been given to the subject by Mr. Jernigan and has resulted well as a valuable work.

NEW YORK HERALD.

This book has the merit of treating within a single pair of covers matter that has hitherto been scattered through a dozen or more volumes. . . We have confidence in the accuracy of the work and Mr. Jernigan has used the material from other writers as 
the authors thenselves intended it to be used and there is notwisting of data to suit the purposes of the author. . . We class this book as giving a very fair idea of China and its inhabitants and as worthy of close study.

\section{BAITIMORE SUN.}

Altogetler this volume is filled with matter interesting both to the general reader and to the scholar, is written by a thoughtful student on the ground and will put money into the pockets of American manufacturers if they will heed its precepts.

SOUTHERN HISTORICAI, SOCIETY.

There is a great deal that is valuable in Mr. Jernigan's book and his statements are accurate.

ATHENEUM.

The book as a whole is highly recommended as that of a keen and thoughtful observer, who is a conmercial man first, and a politician and plilanthropist after.

SCOTSMAN.

It is an unpretentious book containing a large amount of well-selected and well-arranged information.

SPECTATOR.

The information furnished us by Mr. Jernigan in this book is of the solid and serious sort, and his plain, straiglitforward, businesslike style, the ease with which he handles details, his moderation, candor and fairness inspire confidence at once. Not only to the mercluant who has business dealings with China, to the tourist proposing to visit China, to the missionary making the Middle Kingdom his hone will this book be of service ; it will answer for us all a thousand questions suggested by current discussions of affairs in 
the Far East, and clear 11 p as well some stibborn occidental misapprehensions concerning a country of which we talk so much and k11ow so little.

STANDARD.

Mr. Jernigan is an American, who dates from Shanghai, and he is evidently thoronghly well informed on his subjects. His book is a treasury of valuable facts as to the laws and constitution of China and the social conditions of the Chinese.

WESTMINSTER GazeTTE.

In view of the approacling era of commercial and ind1strial development in China, and the obstacles presented by the Chinese language to those who desire to obtain a knowledge regarding Chinese law and commercial practice at first hand, this book is both exceptionally timely and valuable.

DUN'S INTERNATIONAL REVIEW.

The thing essential in compiling a book of this kind is sympathetic perception, and Mr. Jernigan has evidently cultivated this faculty during his residence in China with no little success.

LONDON TIMES.

The work is an excellent presentation of the whole Chinese system in clear and plain statement and is a work alike interesting and valuable for the information which it affords.

ST. JoHN GLOBH.

The general reader will welcome the present volume, seeing that it leals largely with those facts regarding China which undergo little cliange, and which are from their very nature least susceptible to foreign influences.

LONDON AND CHINA TELEGRAPH. 
This book is well calculated to stimulate interest in the vast, undeveloped resources of China. In all the chapters the author takes pains to set the Chinese point of view clearly before the western reader.

MANCHESTER GUARDIAN.

Mr. Jernigan has given us a very useful bonk on many substantial subjects intiniately connected with Chinese history.

THE ECONOMIST.

A thorough study of the legal and commercial relations of China and the Chinese people with the rest of the world, and an analysis of the legal and comnercial aspects of life in the Celestial Empire, is presented by Mr. T. R. Jeruigan in a scholarly volnme entitled "China In Law and Commerce." REVIEW OF REVIEWS. 







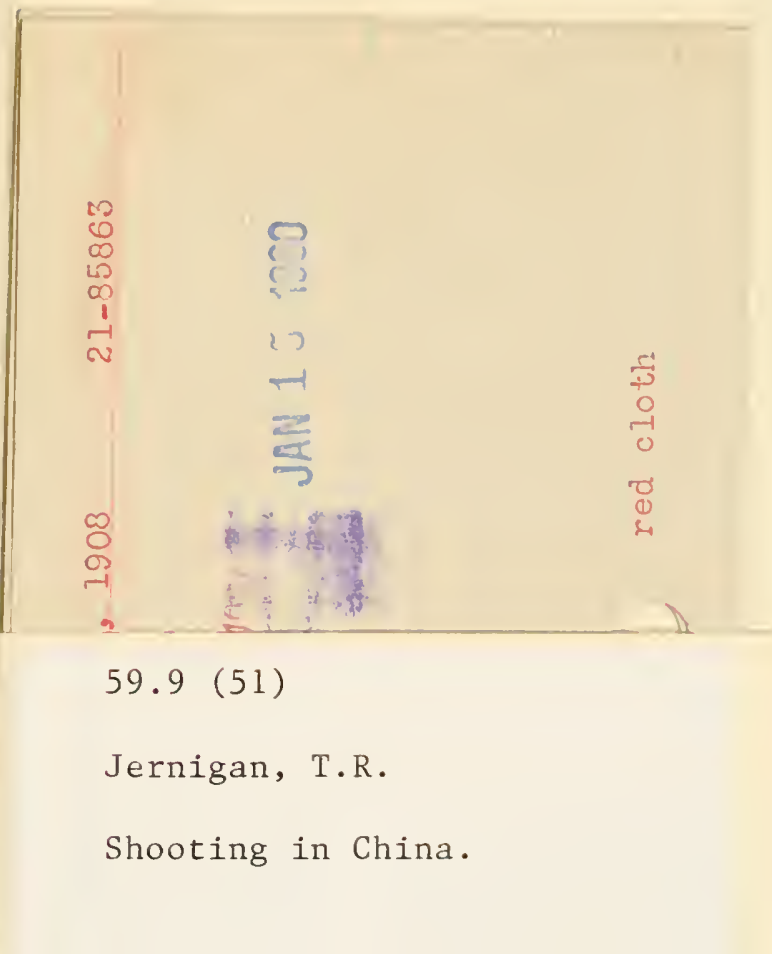


